\title{
Petrology and Depositional Facies of Siliciclastic Rocks of the Middle Ordovician Simpson Group, Mazur Well, Southeastern Anadarko Basin, Oklahoma
}

\section{U.S. GEOLOGICAL SURVEY BULLETIN 1866-E}

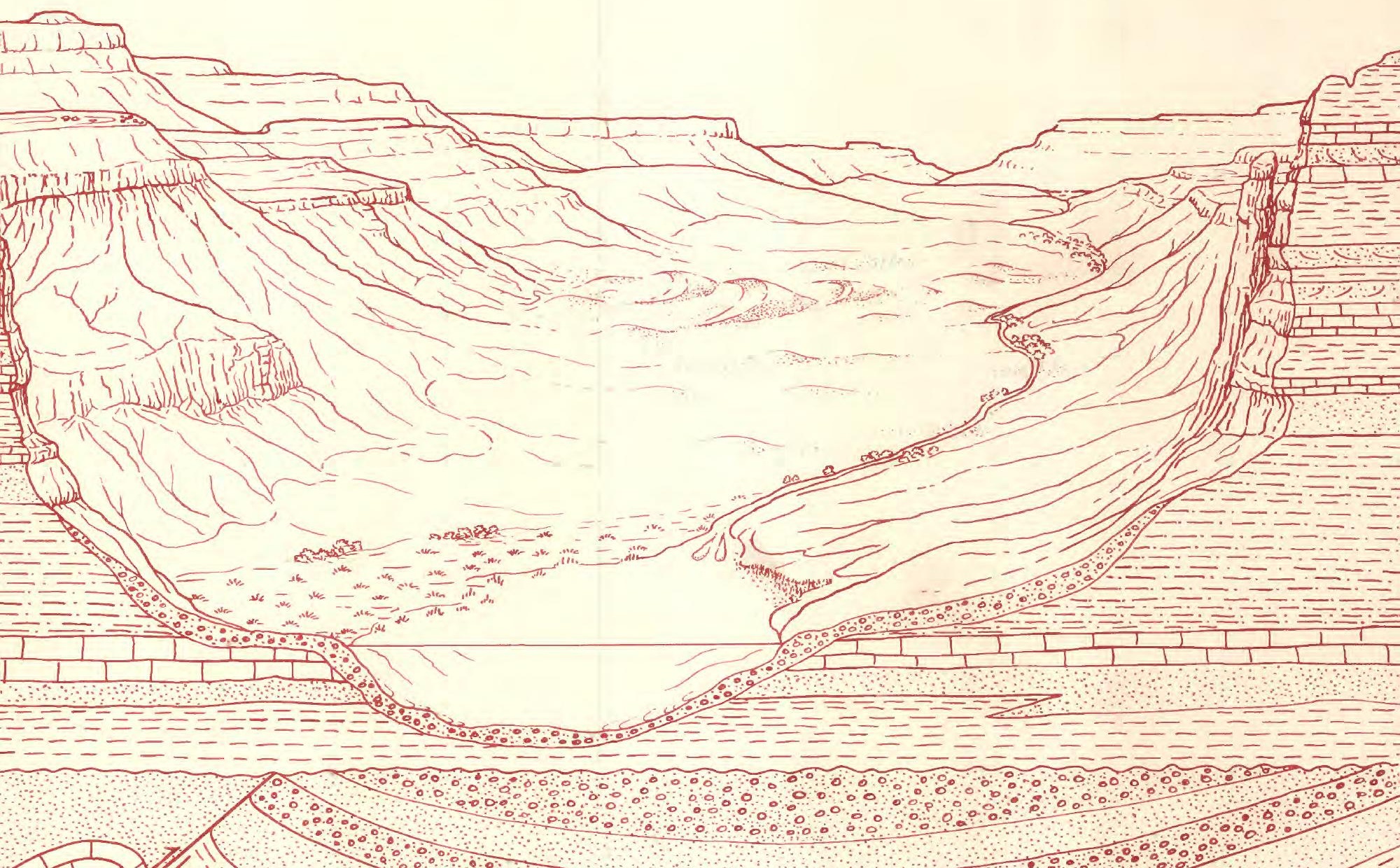


Instructions on ordering publications of the U.S. Geological Survey, along with prices of the last offerings, are given in the current-year issues of the monthly catalog "New Publications of the U.S. Geological Survey." Prices of available U.S. Geological Survey publications released prior to the current year are listed in the most recent annual "Price and Availability List." Publications that are listed in various U.S. Geological Survey catalogs (see back inside cover) but not listed in the most recent annual "Price and Availability List" are no longer available.

Prices of reports released to the open files are given in the listing "U.S. Geological Survey Open-File Reports," updated monthly, which is for sale in microfiche from the U.S. Geological Survey, Books and Open-File Reports Section, Federal Center, Box 25425, Denver, CO 80225. Reports released through the NTIS may be obtained by writing to the National Technical Information Service, U.S. Department of Commerce, Springfield, VA 22161; please include NTIS report number with inquiry.

Order U.S. Geological Survey publications by mail or over the counter from the offices given below.

\section{BY MAIL}

\section{Books}

Professional Papers, Bulletins, Water-Supply Papers, Techniques of Water-Resources Investigations, Circulars, publications of general interest (such as leaflets, pamphlets, booklets), single copies of Earthquakes \& Volcanoes, Preliminary Determination of Epicenters, and some miscellaneous reports, including some of the foregoing series that have gone out of print at the Superintendent of Documents, are obtainable by mail from

\section{U.S. Geological Survey, Books and Open-File Reports Federal Center, Box 25425 \\ Denver, CO 80225}

Subscriptions to periodicals (Earthquakes \& Volcanoes and Preliminary Determination of Epicenters) can be obtained ONLY from the

\section{Superintendent of Documents \\ Government Printing Office \\ Washington, D.C. 20402}

(Check or money order must be payable to Superintendent of Documents.)

\section{Maps}

For maps, address mail orders to

$$
\begin{gathered}
\text { U.S. Geological Survey, Map Distribution } \\
\text { Federal Center, Box } 25286 \\
\text { Denver, CO } 80225
\end{gathered}
$$

Residents of Alaska may order maps from

\author{
Alaska Distribution Section, U.S. Geological Survey, \\ New Federal Building - Box 12 \\ 101 Twelfth Ave., Fairbanks, AK 99701
}

\section{OVER THE COUNTER}

\section{Books}

Books of the U.S. Geological Survey are available over the counter at the following Geological Survey Public Inquiries Offices, all of which are authorized agents of the Superintendent of Documents:

- WASHINGTON, D.C.--Main Interior Bldg., 2600 corridor, 18 th and C Sts., NW.

- DENVER, Colorado-Federal Bldg., Rm. 169, 1961 Stout St.

- LOS ANGELES, California--Federal Eldg., Rm. 7638, 300 N. Los Angeles St.

- MENLO PARK, California-Bldg. 3 (Stop 533), Rm. 3128, 345 Middlefield Rd.

- RESTON, Virginia--503 National Center, Rm. 1C402, 12201 Sunrise Valley Dr.

- SALT LAKE CITY, Utah--Federal Bldg., Rm. 8105, 125 South State St.

- SAN FRANCISCO, Callfornia--Customhouse, Rm. 504, 555 Battery St.

- SPOKANE, Washington--U.S. Courthouse, Rm. 678, West 920 Riverside Ave..

- ANCHORAGE, Alaska--Rm. 101, 4230 University Dr.

- ANCHORAGE, Alaska--Federal Bldg, Rm. E-146, 701 C St.

Maps

Maps may be purchased over the counter at the U.S. Geological Survey offices where books are sold (all addresses in above list) and at the following Geological Survey offices:

- ROLLA, Missouri--1400 Independence Rd.

- DENVER, Colorado--Map Distribution, Bldg. 810, Federal Center

- FAIRBANKS, Alaska--New Federal Bldg., 101 Twelfth Ave. 
Chapter E

Petrology and Depositional Facies of Siliciclastic Rocks of the Middle Ordovician Simpson Group, Mazur Well, Southeastern Anadarko Basin, Oklahoma

\section{BY ROMEO M. FLORES and C. WILLIAM KEIGHIN}

A multidisciplinary approach to research studies of sedimentary rocks and their constituents and the evolution of sedimentary basins, both ancient and modern 


\title{
DEPARTMENT OF THE INTERIOR \\ MANUEL LUJAN, JR., Secretary
}

\author{
U.S. GEOLOGICAL SURVEY
}

Dallas L. Peck, Director

Any use of trade, product, or firm names in this publication is for descriptive

purposes only and does not imply endorsement by the U.S. Government.

UNITED STATES GOVERNMENT PRINTING OFFICE: 1989

For sale by the

Books and Open-File Reports Section

U.S. Geological Survey

Federal Center, Box 25425

Denver, CO 80225

\section{Library of Congress Cataloging-in-Publication Data}

Flores, Romeo M.

Petrology and depositional facies of siliciclastic rocks of the Middle

Ordovician Simpson group, Mazur Well, southeastern Anadarko Basin,

Oklahoma.

(Evolution of sedimentary basins-Anadarko Basin ; ch. E) (U.S.

Geological Survey bulletin ; 1866-E)

"A multidisciplinary approach to researach studies of sedimentary rocks and their constituents and the evolution of sedimentary basins, both ancient and modern."

Bibliography: $p$.

Supt. of Docs. no.: 19.3:1866-E

1. Sandstone-Anadarko Basin. 2. Geology, Stratigraphic-Ordovician.

3. Geology-Anadarko Basin.

I. Keighin, C. William. II. Title. III. Title: Simpson group, Mazur Well, southeastern Anadarko Basin, Oklahoma. IV. Series. V. Series: U.S.

Geological Survey bulletin ; 1866-E.

QE75.B9 no. 1866-E 557.3 s [552'.5]

$89-600196$ [QE471.15.S25] 


\section{CONTENTS}

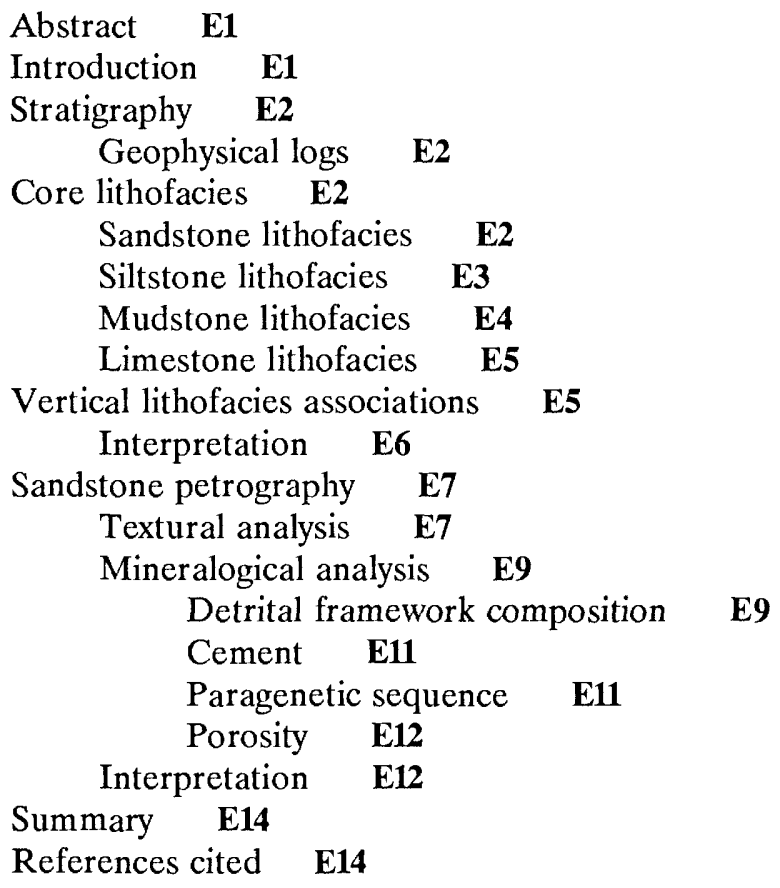

Appendix 1-Photographs of core recovered from the Middle Ordovician Simpson Group E18

Appendix 2-Photographs of selected sedimentologic and (or) lithologic features in core from the Middle Ordovician Simpson Group $\quad$ E32

Appendix 3-Photomicrographs showing features typical of core samples from the Middle Ordovician Simpson Group E39

\section{FIGURES}

1. Map showing location of Mazur well and Knox oil field in southeastern Anadarko basin of Oklahoma in relation to major tectonic features E1

2. Generalized stratigraphic column for Middle Ordovician Simpson Group, Arbuckle Mountains E2

3. Logs for Mazur well showing response of various logging tools, cored intervals, and formation tops $\mathbf{E 3}$

4. Geophysical logs showing response of various logging tools for Simpson Group interval in Mazur well

\section{E4}

5-8. Gamma-ray and lithologic logs for Mazur well:

5. McLish, Tulip Creek, and Bromide Formations

E6

6. Cycle 1, Tulip Creek Formation

E8

7. Cycle 2, lower member of Bromide Formation E9

8. Cycle 3, upper member of Bromide Formation E10

9. Map and cross sections showing location of Mazur well in relation to aulacogen that existed in southern Oklahoma from Late Cambrian to Early Devonian time 
10. Frequency histograms of quartz grains in sandstones of cycles 1, 2, and 3, Mazur well E13

11. Quartz-feldspar-total rock fragments ternary diagram showing major mineral composition and classification of sandstones from the Mazur well E13

12. Diagram showing postdepositional and burial diagenetic history of sandstones from the Mazur well E13

\section{TABLES}

1. Grain-size properties of sandstones of the Simpson Group, Mazur well E11

2. Mineral composition of sandstones of the Simpson Group, Mazur well E12

CONVERSION FACTORS FOR SOME SI METRIC AND U.S. UNITS OF MEASURE

\begin{tabular}{lll}
\hline \multicolumn{1}{c}{ To convert from } & \multicolumn{1}{c}{ To } & \multicolumn{1}{c}{ Multiply by } \\
\hline Feet $(\mathrm{ft})$ & Meters $(\mathrm{m})$ & 0.3048 \\
Miles $(\mathrm{mi})$ & Kilometers $(\mathrm{km})$ & 1.609 \\
Pounds $(\mathrm{lb})$ & Kilograms $(\mathrm{kg})$ & 0.4536 \\
Degrees Fahrenheit $\left({ }^{\circ} \mathrm{F}\right)$ & Degrees Celsius $\left({ }^{\circ} \mathrm{C}\right)$ & Temp ${ }^{\circ} \mathrm{C}=\left(\right.$ temp $\left.{ }^{\circ} \mathrm{F}-32\right) / 1.8$ \\
\hline
\end{tabular}




\title{
Petrology and Depositional Facies of Siliciclastic Rocks of the Middle Ordovician Simpson Group, Mazur Well, Southeastern Anadarko Basin, Oklahoma
}

\author{
By Romeo M. Flores and C. William Keighin
}

\begin{abstract}
The Mazur well in the southeastern Anadarko basin of Oklahoma penetrates the McLish (oldest), Tulip Creek, and Bromide Formations of the upper part of Middle Ordovician Simpson Group. Lithofacies and petrographic analysis of 650 $\mathrm{ft}$ of core indicates deposition in a rapidly subsiding aulacogen. Lithofacies associations suggest that the deposits accumulated in cycles that consist of mudstone-siltstonelimestone in the lower part of the lithofacies sequence and quartzarenite in the upper part. The lithofacies sequence in the lower part of the cycles is interpreted as deposits of subtidal to intertidal environments. The lithofacies sequences in the upper part of the cycles are deposits of tidal channels.

The sandstones are made up of generally rounded and well-sorted to moderately sorted quartz grains and exhibit highly quartzose characteristics. They consist of framework grains and cement and lack detrital matrix. The framework grains are composed of monocrystalline and polycrystalline quartz (as much as 99 percent); feldspar (as much as 4 percent) including orthoclase, microcline, and perthite; and rock fragments (as much as 12 percent) consisting of chert, micaceous rock fragments, siltstone, shale, limestone, glauconite, collophane, and skeletal fossil fragments. Cements include silica, carbonate, and clay. The silica cement consists of quartz. overgrowths, and the carbonate cement comprises calcite, ferroan calcite, ferroan dolomite, and ankerite. The mineralogical and textural maturity of the sandstones suggests deposition in tidal-influenced environments in which winnowing by waxing and waning tidal currents promoted clean, mature sediments.
\end{abstract}

\section{INTRODUCTION}

Extensive drilling in the Anadarko basin, a major hydrocarbon-producing basin in Oklahoma, has yielded a

Manuscript approved for publication, May 26, 1989.

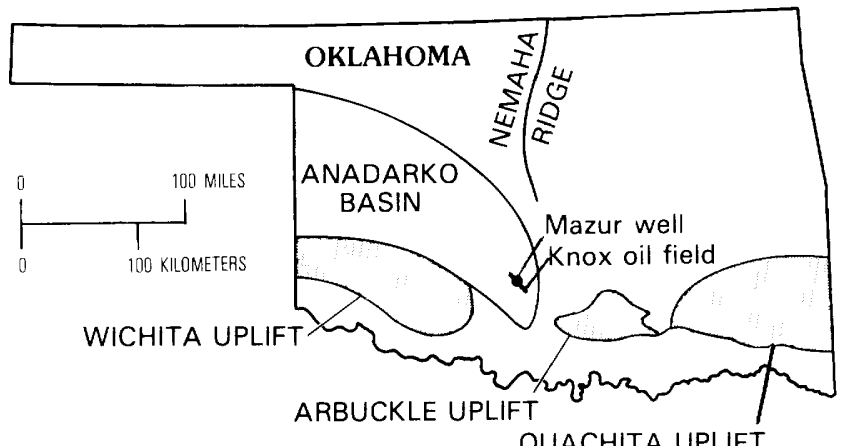

OUACHITA UPLIFT

Figure 1. Location of the Mazur well and Knox oil field in the southeastern Anadarko basin of Oklahoma in relation to major tectonic features.

large collection of Paleozoic cores. The core described in this report is from the Sunray Parker DX No. 1 Mazur well and consists of rocks from the middle part of the Upper Cambrian and Lower Ordovician Arbuckle Group and the upper part of the Middle Ordovician Simpson Group. The well is in southeastern Grady County (sec. 1, T. 3 N., R. 5 W.), in the southeastern part of the Anadarko basin (fig. 1). It is in the Knox oil field, from which gas is produced from the McLish and Bromide Formations of the upper part of the Simpson Group below depths of 15,000 ft (Kennedy, 1982).

The purpose of this report is to describe the lithofacies and petrography of $650 \mathrm{ft}$ of core from the upper part of the Simpson Group in the Mazur well and to interpret the environments of deposition. Lithology, sedimentary structures, trace and body fossil content, and contact relationships are described for each rock unit. Textures and mineralogical compositions of the sandstones were estimated from 29 thin sections. In addition, geophysical log responses, including gamma- 
ray, sonic, neutron, resistivity, conductivity, and density, are related to lithology and depositional facies.

Acknowledgments. - We acknowledge the assistance of the Oklahoma Geological Survey, Charles J. Mankin, Director, in providing access to the core, and to Eldon Cox and Walter Esry, Oklahoma Geological Survey Core and Sample Library, for their generous help.

\section{STRATIGRAPHY}

The interval of the Simpson Group studied in the Mazur core includes parts of the McLish, Tulip Creek, and Bromide Formations. A generalized stratigraphic column for the Simpson Group in the Arbuckle Mountains is shown in figure 2 (Ham, 1969; Johnson and others, 1984). The Arbuckle section has been used by Schramm (1964) and Borras (1979) as reference to the Simpson rock units in the Anadarko basin. Although lithologies in the Mazur core are similar to those of the Arbuckle section, the Mazur core contains less limestone and the thicknesses of units are different.

The upper $220 \mathrm{ft}$, or upper third, of the McLish Formation was cored in the Mazur well (fig. 3). The McLish is composed of interbedded sandstone, conglomeratic sandstone, siltstone, mudstone, and limestone; about 60 percent of the formation is composed of sandstone and conglomeratic sandstone. The McLish grades upward into the Tulip Creek Formation, which is $235 \mathrm{ft}$ thick; the uppermost $55 \mathrm{ft}$ of the cored interval is missing (fig. 3). The Tulip Creek consists of sandstone, conglomeratic sandstone, siltstone, mudstone, and limestone; about 90 percent of the

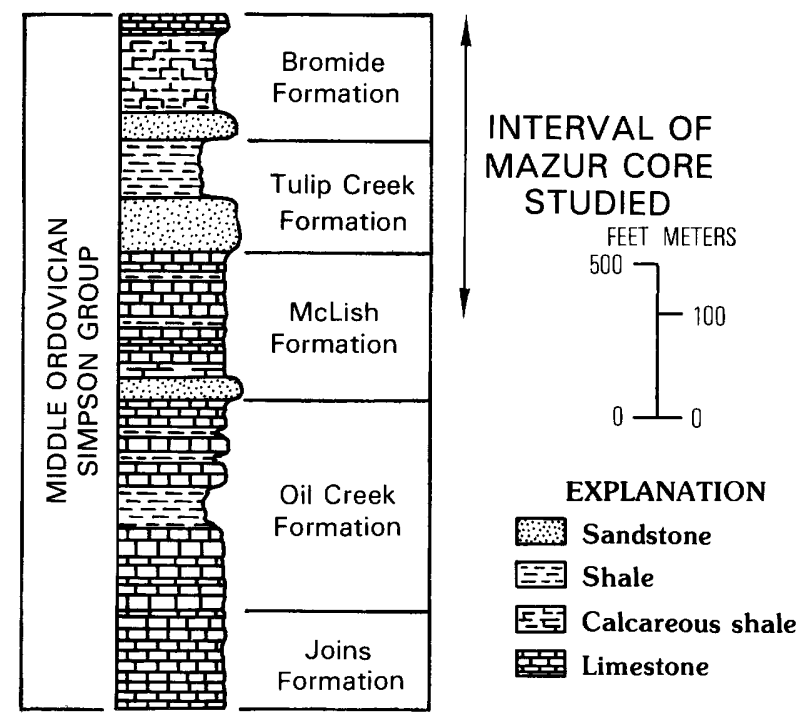

Figure 2. Generalized stratigraphic column for the Middle Ordovician Simpson Group in the Arbuckle Mountains. Modified from Ham (1969) and Johnson and others (1984). formation is composed of sandstone and conglomeratic sandstone. The Bromide Formation, $295 \mathrm{ft}$ thick, overlies the Tulip Creek (fig. 3). The contact between the two formations was not observed because $50 \mathrm{ft}$ of core is missing. The Bromide Formation includes a lower member, $125 \mathrm{ft}$ thick, and an upper member, $170 \mathrm{ft}$ thick. It consists mainly of interbedded sandstone, siltstone, mudstone, and limestone; however, the lower part contains thick sandstone units. The formation as a whole contains about 35 percent sandstone; the sandstone is concentrated in the lower part and vertically dispersed in the upper part.

The cored interval of the Simpson Group contains about 60 percent sandstone and conglomeratic sandstone. The McLish interval in the well is more sandy than in other areas in the Anadarko basin, where it contains only as much as 25 percent sandstone. In the cored interval, the Tulip Creek Formation includes as much as 100 percent sandstone and the Bromide Formation as much as 35 percent sandstone (Borras, 1979).

\section{Geophysical Logs}

Gamma-ray, sonic, neutron, resistivity, conductivity, and density logs are available for portions of the Mazur well. Available logs of suitable quality in the interval of principal interest were digitized so that the log curves could be compared with the lithologies observed in the cores. Gamma-ray, sonic, and neutron logs display the most graphic response to changes in lithology (fig. 4); log responses (figs. 3-8) may be compared with the lithologies illustrated and with the photographs of cores included in appendix 1.

Sandstones, or sandy intervals, and dark, waxy mudstones are clearly visible on the gamma-ray logs. The only $\log$ available through the cored interval to the total depth of the hole is the gamma-ray log (fig. 3); it indicates that, except for the Oil Creek Formation, few sandstones are found below the McLish Formation.

\section{CORE LITHOFACIES}

\section{Sandstone Lithofacies}

The white to gray sandstones vary from very fine to medium grained to conglomeratic. The conglomeratic sandstones consist of granule- to pebble-size clasts of quartz, mudstone, siltstone, limestone, and fossil (brachiopods and crinoids) fragments that occur either as basal lag deposits in the sandstone or distributed throughout the sandstone. Basal contacts are sharp to erosional; multiple erosional contacts (appendix 2-1) 


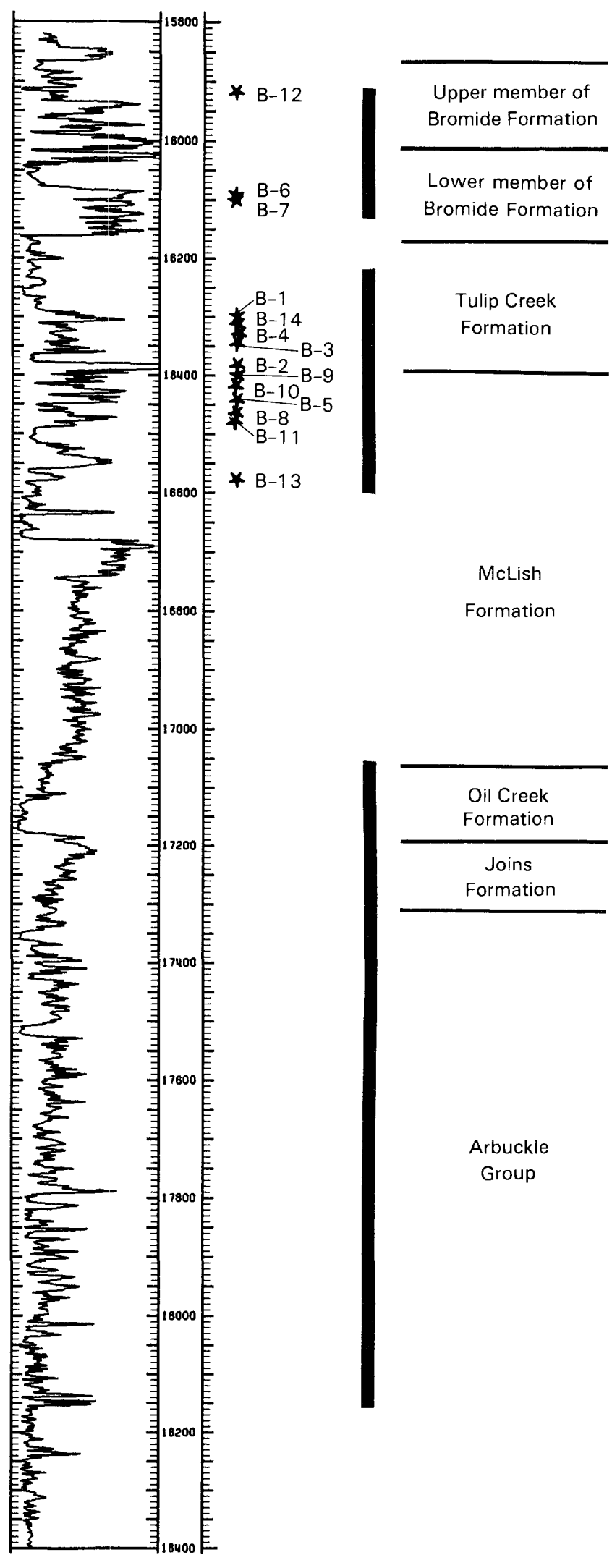

occur in the sandstones. The white sandstones are wellsorted, locally calcareous or calcite-cemented quartz-
Figure 3 (facing column). Gamma-ray log for Mazur well showing cored intervals (heavy lines), formation tops (picked from logs), and locations (asterisks) and numbers of photographs of core shown in appendix 2 (referred to by prefix B). Log to total depth of well; depth below surface (in feet) shown.

arenites. The gray sandstones are litharenites and contain a higher proportion of rock fragments than the quartzarenites. Quartzarenites are more common than litharenites.

The sandstones contain cross-laminated, ripplelaminated, parallel-laminated, and convoluted bedding (fig. 5; appendix 2-2, 2-3, 2-4). These sedimentary structures show the following combinations of vertical sequences: (1) cross laminations in the lower part of the sequence and ripple laminations in the upper part; (2) parallel laminations in the lower part of the sequence and ripple laminations in the upper part; and (3) multiple successions or series of cross laminations and ripple laminations as well as parallel laminations and some convolutions. Inclinations of cross laminations show bimodal orientation and range from $5^{\circ}$ to $20^{\circ}$. The cross laminations are from 2 to 11 in. thick and are commonly defined by layers of finely divided plant fragments. The sandstones also contain many bioturbated beds (appendix 2-5) that are interbedded with crosslaminated, ripple-laminated, and parallel-laminated beds. The burrows are nondescript, horizontal and vertical, tubelike structures; vertical burrows are more common.

\section{Siltstone Lithofacies}

The siltstones are dark gray to light gray to white, depending on quartz content (appendix 2-6). A few of the sandy siltstones are arkosic, comprising 20-25 percent feldspar (mainly orthoclase) (appendix 3-1). The siltstones show gradational upper and lower contacts where they are interbedded with mudstones and erosional contacts where they are overlain by sandstones. The siltstones are commonly ripple laminated (asymmetrical ripple laminations; appendix 2-7). Flaser bedding is developed where siltstones are intercalated with mudstones; pinstripe burrows are formed in the mudstones that bind the flasered units (appendix 2-8). Horizontal and vertical burrows of unknown origin are common in the siltstones, and horizontal bioturbation is more common than in the sandstones. Fragments of crinoid columnals and brachiopod shells commonly occur as lenses. 


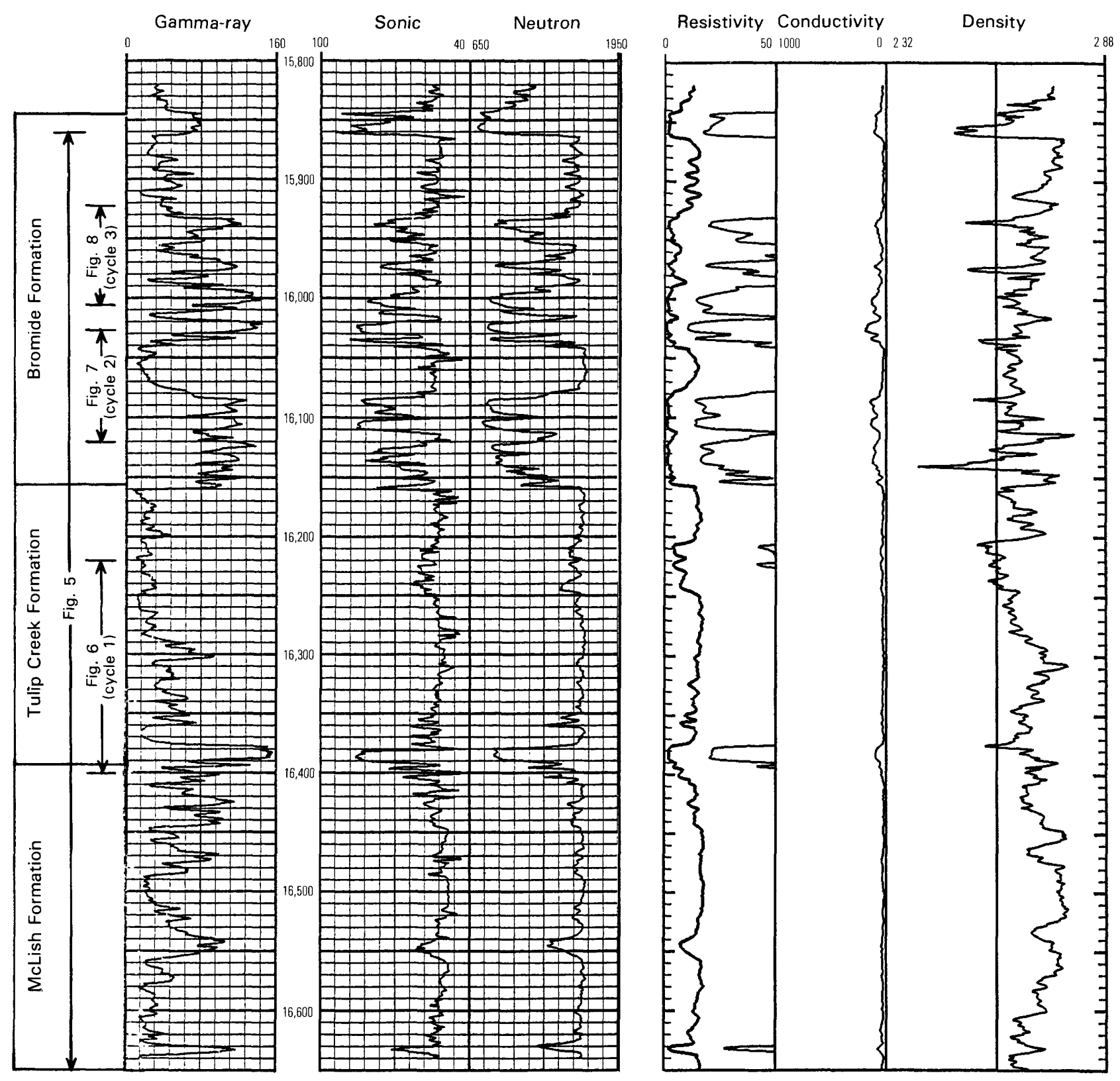

Figure 4. Response of various logging tools for the Simpson Group interval in the Mazur well. Selected intervals are shown in greater detail in figures 5-8; location of cycles shown in figures 6-8 is marked. Depth below surface (in feet) shown.

\section{Mudstone Lithofacies}

The mudstones are waxy and dark gray to black; black mudstones contain abundant finely divided plant fragments (appendix 2-9). Most mudstones are calcareous. Contacts with most adjoining rock types are gradational, but where overlain by sandstone the contact is erosional. The mudstones are locally fissile and splintery and may correctly be classified as muddy shales. X-ray diffraction analysis (Weber, 1987) indicates that the clay fraction in the shale of the McLish is mainly composed of illite and some chlorite. Sedimentary structures include laminations that are apparent when the core is freshly cut. Some of the mudstones are interlaminated with thin, white, quartzose silty units that form parallel and ripple laminations, but most of the primary structures of the mudstones have been obliterated by bioturbation (appendix 2-10). Trace fossils (Planolites, Trichophyens, and Dictyodora) are common burrows in shales and mudstones of the Bromide Formation (Longman, 1981). Most of these animal burrows are interpreted as feeding traces. Body fossils of transported and abraded crinoid and brachiopod fragments also were found. 


\section{Limestone Lithofacies}

The limestones are light to dark gray, and contacts with adjoining rock types are generally gradational to sharp. The limestones (appendix 2-11) vary from micrite to biomicrite (Folk, 1959). Most of the limestones are nodular or lumpy bedded (appendix 2-12). The nodules are as thick as 2 in. and as long as 3 in. Longman (1981) suggested that nodular-bedded limestones in the Bromide Formation are caused by concentrations of shell fragments. The nodules comprise white biosparite bounded by dark-gray micrite. Massive limestones consisting of sparse biomicrite are also common.

Limestones of the McLish Formation have been classified as wackestones to grainstones by Weber (1987). They consist of fossil fragments of echinoderms, bryozoans, trilobites, brachiopods, and ostracods. Limestones of the Tulip Creek and Bromide Formations commonly contain well-rounded crinoid, brachiopod, and bryozoa bioclasts (as much as 40 percent) (appendix 3-2). Subordinate allochemical fragments of limestone include micritic pelletoids and ooids. Minor amounts of quartz, feldspar, and collophane (as pyritized brachiopod fragments) grains make up the remaining constituents of the limestones. The allochemical and detrital grains are bounded by micritic calcite and cemented by sparry calcite, ferroan calcite, dolomite, and ankerite (appendix 3-3). Fine-grained dolomites are associated with fossiliferous biomicrite.

Most of the sedimentary structures of the limestones are spar- and micrite-filled, tubular, vertical and horizontal burrows and burrow-mottles. V-shaped dessication mud cracks (appendix 2-13) are perpendicular to bedding planes and filled by micrite or sparite (appendix 2-13). Some clasts in the limestones appear to have been derived from the mud cracks. Shell fragments of brachiopods and crinoids (appendix 2-14) are the most important bioclasts and are concentrated in lenses or scattered throughout. Stylolites, which represent a diagenetic feature due to compaction, are common. A few small-scale cross laminations were observed.

\section{VERTICAL LITHOFACIES ASSOCIATIONS}

An inspection of the vertical lithofacies sequence shows cyclic repetition of rock types. The lithofacies associations consist of a lower mudstone unconformably overlain by quartzarenite. In other parts of the study interval, mudstone interbedded with limestone is overlain by siltstone. Thus, where quartzarenite unconformably overlies mudstone, it is assumed that the associated siltstone and limestone have been eroded.
The lithofacies association of quartzarenite and mudstone occurs in the McLish, Tulip Creek, and Bromide Formations. In the McLish, it is as thick as $85 \mathrm{ft}$; in the Tulip Creek, it is more than $200 \mathrm{ft}$ thick and makes up almost the entire formation; in the Bromide Formation, the sequence is as thick as $75 \mathrm{ft}$. In addition, the Bromide Formation contains numerous thin intervals $(10-40 \mathrm{ft}$ thick) of the quartzarenite-mudstone lithofacies association. These vertical lithofacies associations occur throughout the upper part of the Simpson Group and are typified by the three cycles as shown in figures 5-8.

Cycle 1 (fig. 6), in the Tulip Creek Formation, consists of mudstone, $10 \mathrm{ft}$ thick, unconformably overlain by quartzarenite, $160 \mathrm{ft}$ thick. The quartzarenite consists of multiple erosional-based sandstones that contain granule- to pebble-size particles or conglomeratic sandstones. The cycle contains a few thin limestones. The sandstone units are $2-40 \mathrm{ft}$ thick and each unit contains a succession of cross, parallel, and ripple laminations commonly interrupted by burrowed units.

The basal mudstone of cycle 1 is represented by a distinctive peak on the gamma-ray log (figs. 5, 6). Although core is missing from this interval (fig. 3), the top of the cycle, on the basis of log response, is probably approximately $16,160 \mathrm{ft}$ below the surface.

Cycle 2 (figs. 5, 7), $75 \mathrm{ft}$ thick, is developed in the lower member of the Bromide Formation. It includes a mudstone, $30 \mathrm{ft}$ thick, that is burrowed, silty, and fossiliferous in the lower part and grades upward into a burrowed, rippled, quartzose siltstone, $5 \mathrm{ft}$ thick, interbedded with mudstone. The siltstone is, in turn, unconformably overlain by a quartzarenite $35 \mathrm{ft}$ thick; the uppermost $5 \mathrm{ft}$ of the quartzarenite is a scour-based sandstone. Internal structures are a succession of cross laminations and ripple laminations separated by bioturbated zones. The uppermost scour-based quartzarenite contains lag deposit of shells of crinoid and brachiopod fossils. Cycle 2 (fig. 7) is not as clearly defined by gamma-ray response as cycle 1 ; individual units and (or) beds are thinner, and it is difficult to place precise cycle boundaries on the basis of $\log$ response.

Cycle 3 (fig. 8), about $30 \mathrm{ft}$ thick, is in the upper member of the Bromide Formation. It consists of a burrowed mudstone, $8 \mathrm{ft}$ thick, that grades upward into a rippled, quartzose siltstone, $1 \mathrm{ft}$ thick. The siltstone is unconformably overlain by $15 \mathrm{ft}$ of quartzarenite that displays internal scouring. The quartzarenite is, in turn, conformably overlain by flaser-bedded quartzose siltstone ( $2 \mathrm{ft}$ thick) and calcareous quartzarenite $(4 \mathrm{ft}$ thick). The scale of bedding in cycle 3 (fig. 8) is small enough that logs are of very limited utility in defining cycles. 
GAMMA

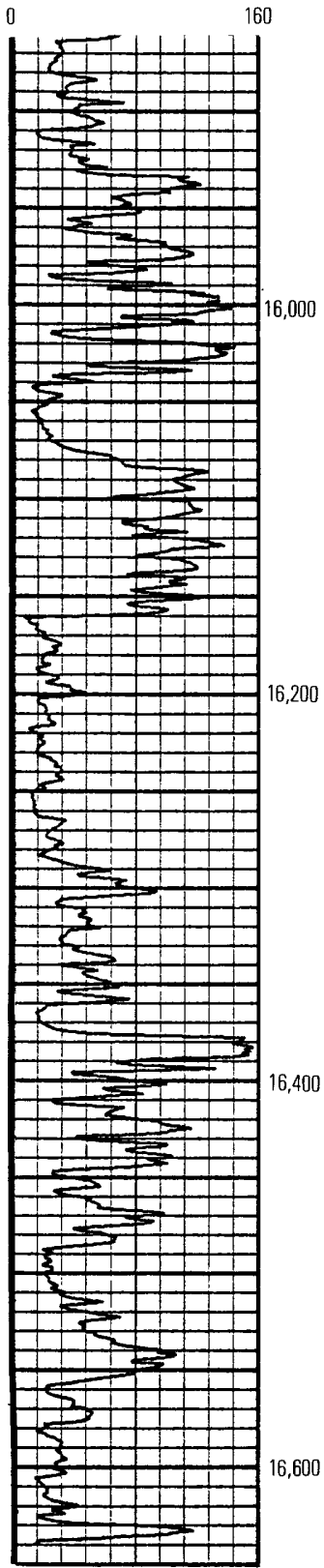

SEDIMENTARY LITHOLOGY STRUCTURES

11 I

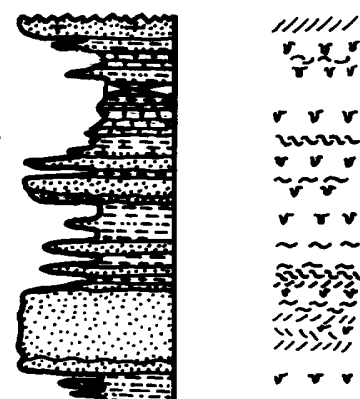

DESCRIPTION

LITHOLOGIC
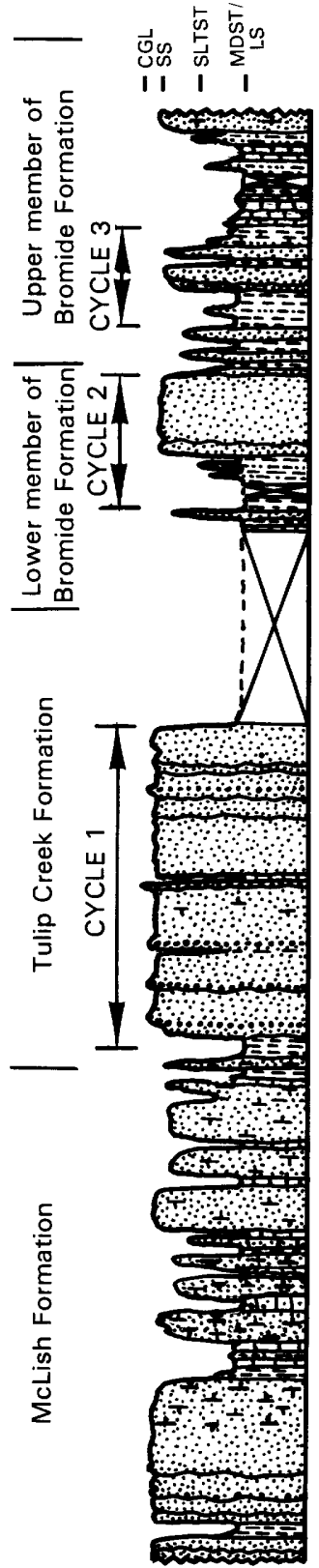

Sandstone, fine-grained, white, low-angle cross laminations

Sandstone, siltstone, mudstone, limestone; locally fossiliferous with brachiopod shells; quartzose sandstone

Sandstone, fine-grained, white, calcareous, silty and muddy units

Sandstone, siltstone, and mudstone; quartzose, fine-grained sandstone; waxy black mudstone

Sandstone, fine-grained, white, low-angle cross laminations local scours

Siltstone, gray, quartzose

(Missing interval)

Mudstone, black, waxy, silty; with quartzose sandstone and limestone interbeds

(Missing interval)

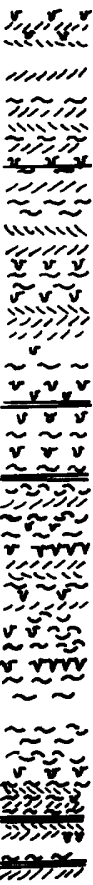

Sandstone, fine-grained, with local fining-upward units (medium to fine grained) and conglomerate units, internal local scours, high- to low-angle cross laminations

Mudstone, black, waxy

Sandstone, fine-grained, white to light-gray, muddy to silty, with limestone units, fossiliferous with crinoid and brachiopod shells

\author{
Sandstone, fine-grained, white, quartzose \\ Limestone, gray, muddy with waxy shale \\ Sandstone, fine-grained, white, quartzose, high-to low-angle \\ cross laminations
}

Mudstone, black, waxy

Sandstone, fine-grained, white

\section{Interpretation}

The precursor of the Anadarko basin was an aulacogen (Hoffman and others, 1974). The aulacogen in southern Oklahoma began with a graben stage of block faulting followed by volcanism and graben filling (late Proterozoic to Middle Cambrian time). The area evolved into a subsiding basin by Late Cambrian to Early Devonian time (fig. 9). Longman (1981) proposed that the Simpson Group was deposited in this subsiding basin and that the McLish, Tulip Creek, and Bromide Formations were deposited during pulses of subsidence. Between these pulses, the aulacogen filled with sediments that passed into a gently dipping, terrigenous mud-dominated subtidal ramp merging with adjacent borderlands. During deposition of the Bromide Formation on this subtidal ramp along the northeast side of the basin, a basin-forebuildup-buildup-lagoon carbonate platform developed (Longman, 1981). Shale was deposited in the basin, micrite in the forebuildup, biosparite in the buildup, and micrite and shale in the lagoon. The lagoonal environment of this carbonate platform probably served as the primary depositional setting for the Simpson Group at the Mazur core site. 


\section{EXPLANATION}

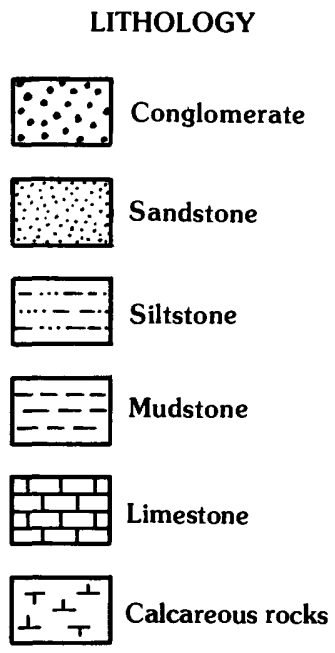

\section{GRAIN SIZE}

Indicated by extent of lithologic column. CGL, conglomerate; SS, sandstone; SLTST, siltstone; MDST/LS, mudstone or limestone

Figure 5 (above and facing page). Gamma-ray and lithologic logs for McLish, Tulip Creek, and Bromide Formations, Mazur well. Depth below surface (in feet) shown.

The cyclic deposits of mudstone-siltstonequartzarenite probably represent seaward outbuilding or progradation of quartzarenites into the lagoonal environment. The mudstone-siltstone-limestone lithofacies association is interpreted as mainly subtidal lagoonal deposits. Flaser bedding in the siltstones suggests deposition in a lagoonal tidal-flat environment (Reineck and Singh, 1980), where tidal fluctuations provided sedimentation of silt during waxing stage and mud during waning stage. Reworking of sediments by feeding animals was prevalent during the waning stage and caused bioturbation. Desication mud cracks in limestones suggest deposition in an intertidal environment, where subaerial exposure contributed to drying of carbonate muds.

The quartzarenites contain erosional bases, multiple internal scours, and conglomeratic units and probably were deposited in channels. The types and succession of sedimentary structures of the quartzarenites are similar to those observed by Kumar and Sanders (1976), Hayes and Kana (1977), and de Mowbray and Visser (1984) in subtidal channel deposits. The lagconglomeratic sandstones consist of reworked clasts and fossil fragments and cross laminations (dunes and megaripples) and represent channel-bottom deposits. Associated ripple laminations and bioturbations reflect structures developed in channel-bar deposits, and the parallel laminations formed in shallow channel deposits. Tidal-flat deposition is probably represented by

bioturbation in the uppermost parts of the quartzarenite units. Multiple scours in the quartzarenites probably represent incised ebb and (or) flood-tidal channels.

The abundance of subtidal channel arenites suggests that the well location was either in close proximity to the source area or in a locus of terrigenous deposition. Schramm (1964) suggested that the point source of these sands was to the northeast, probably the Canadian Shield. Proximity to a locus of terrigenous deposition in a rapidly subsiding basin, however, is probably the more appropriate hypothesis. Deposition in a subtidal lagoon-intertidal setting in a subsiding basin is indicated by the location of the well southwest of the northwest-southeast hingeline of the aulacogen (fig. 9).

\section{SANDSTONE PETROGRAPHY}

The petrography of the sandstones of the Simpson Group was analyzed to determine textural and mineralogical variations of cycles 1,2 , and 3 (tables 1,2 ). Textural analysis included measurements of mean grain size, sorting, skewness, and kurtosis, and mineralogical analysis comprised identification of framework, matrix, and cement composition, as well as recognition of paragenetic sequence and porosity. The petrography of the sandstones was determined by examining 29 epoxyimpregnated and stained (sodium cobaltinitrite, alizarinred-S, and potassium ferricyanide) thin sections.

\section{Textural Analysis}

Quartz grains are fine to medium grained, with mean grain size of $2.22 \phi$. Sandstones of cycles 1 and 2 are generally fine grained, with a mean grain size of 2.32-2.35 $\phi$, and sandstones of cycle 3 are medium grained, with a mean grain size of $1.87 \phi$. Most quartz grains are well rounded; minor quantities of grains are subrounded (appendix 3-4). No apparent difference in roundness of quartz grains was observed between the fine-grained and medium-grained sandstones.

In general, the sandstones are moderately sorted $(0.96 \phi)$; however, sorting varies from moderate $(0.82 \phi)$ to poor $(1.07 \phi)$. Sorting of the sandstones of cycles 1,2 , and 3 is best demonstrated by the frequency distributions of quartz grains shown in figure 10. Frequency distributions in cycles 1 and 2 are unimodal, skewed toward fine grained (0.77-0.91 $\phi)$, and near symmetrical $(0.05 \phi)$. The frequency distribution of cycle 3 is bimodal and skewed strongly toward fine grained $(0.72 \phi)$. Thus, the sandstones of cycle 3 are poorly sorted compared to those of cycles 1 and 2, which are moderately sorted.

The measure of peakedness of the frequency distribution curves of quartz grain size is indicated by kurtosis. In general, the frequency distribution curves are 
GAMMA

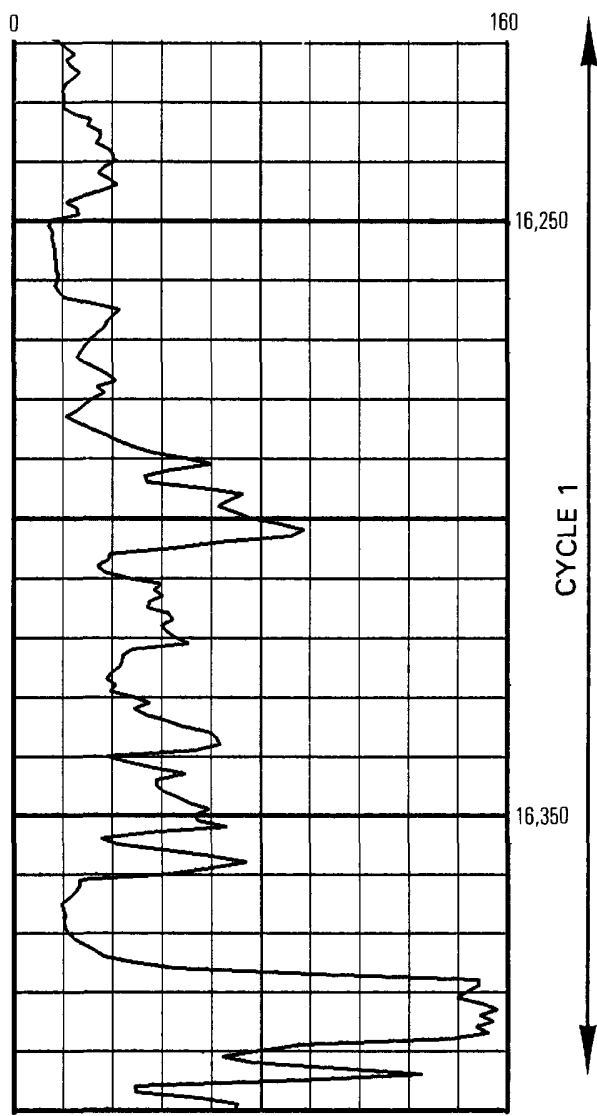

SEDIMENTARY

LITHOLOGY STRUCTURES

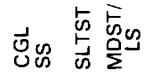

I I I

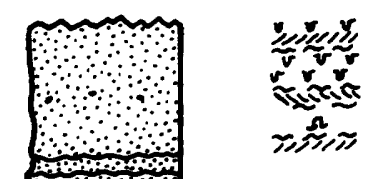

242

$\approx \approx \approx \sim$

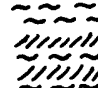

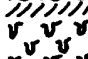

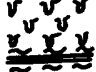

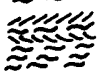

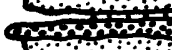

mand

(1)
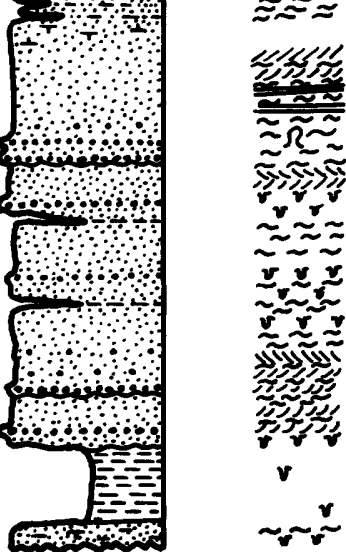

$\tilde{\widetilde{\pi} \tilde{\pi} \sim}$

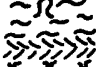

istar

$\tilde{\sim} \approx \tilde{\sim}$

$\tilde{y} \tilde{x} \tilde{x}$
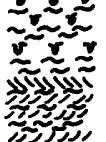

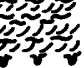

$\boldsymbol{v}$

น

\section{LITHOLOGIC DESCRIPTION}

Sandstone, fine-grained, locally gray, quartzose, low-angle cross laminations, local clasts

Conglomerate, sedimentary rock clasts; fining-upward, medium- to fine-grained sandstone units

Sandstone, fine-grained, white, quartzose, locally contains very thin conglomerate units, high- to low-angle cross laminations

Limestone, gray, no visible sedimentary structures

Sandstone, fine-grained, white, quartzose, contains numerous very thin conglomerate units, some silty-muddy laminations, high- to low-angle cross laminations

Mudstone, black, waxy

Sandstone, fine-grained, white, quartzose, silty to muddy

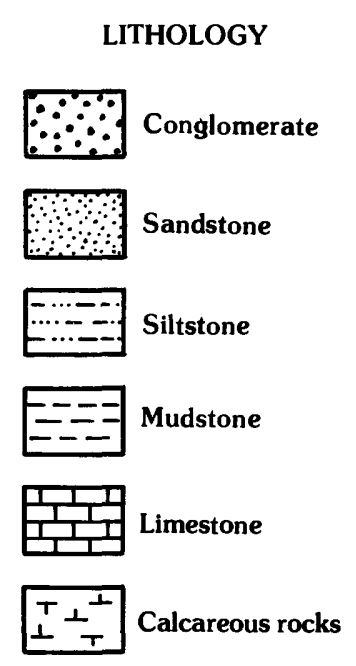

\section{EXPLANATION}

\section{SEDIMENTARY STRUCTURES}

ح $\sim$ Ripple laminations

202นใน Flaser beds

$=$ Parallel laminations

$\Omega$ Convolute laminations

$v_{v} v_{v} v$ Burrows

vrrvr Desiccation cracks

$\cong$ Fossil shells

\section{GRAIN SIZE}

Indicated by extent of lithologic column. CGL, conglomerate; SS, sandstone; SLTST, siltstone; MDST/LS, mudstone or limestone

Figure 6. Gamma-ray and lithologic logs for cycle 1, Tulip Creek Formation, Mazur well. Depth below surface (in feet) shown. 
GAMMA

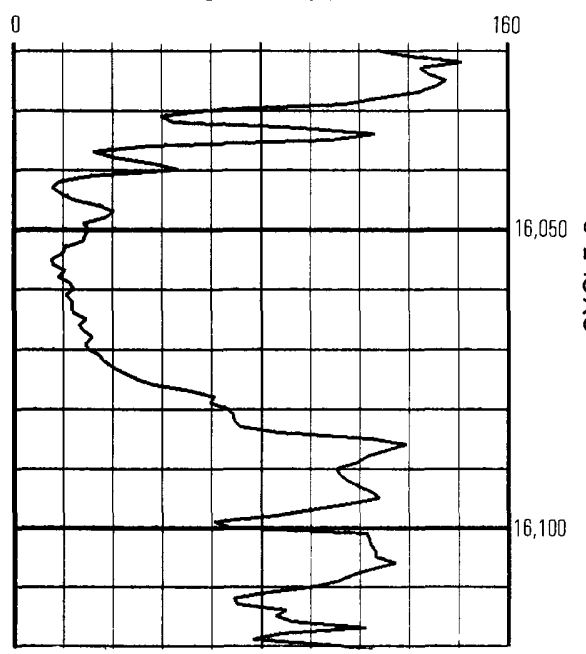

I I I |

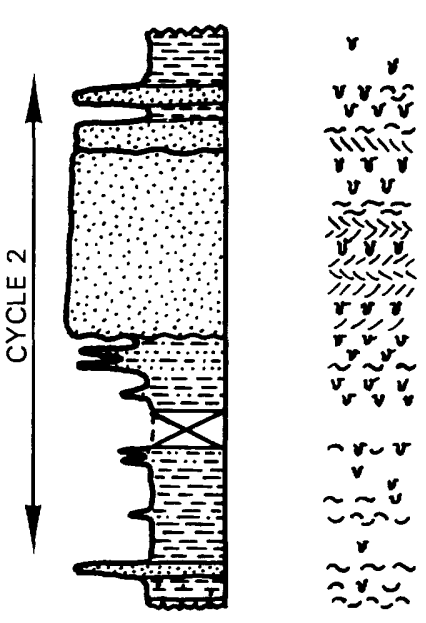

\section{LITHOLOGIC DESCRIPTION}

Mudstone, black, waxy, silty

Sandstone, fine-grained, white, quartzose

Mudstone, black, waxy, silty

Sandstone, fine-grained, white, quartzose

Siltstone, gray, locally quartzose

Mudstone, dark-gray, waxy, silty

(Missing interval)

Mudstone, black, silty

Sandstone, fine-grained, white, quartzose

Limestone, light-gray, fossiliferous with crinoid and brachiopod shells

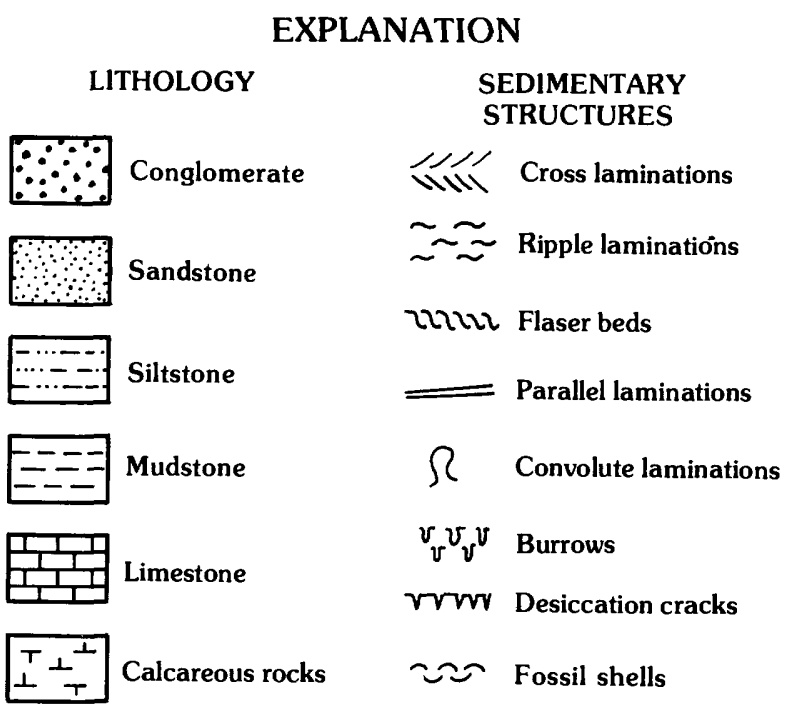

GRAIN SIZE

Indicated by extent of lithologic column. CGL, conglomerate; SS, sandstone; SLTST, siltstone; MDST/LS, mudstone or limestone

Figure 7. Gamma-ray and lithologic logs for cycle 2, lower member of Bromide Formation, Mazur well. Depth below surface (in feet) shown.

platykurtic $(0.78 \phi)$; however, the frequency distribution curves of the quartz grains of cycles 1 and 3 exhibit more peaks (mesokurtic and leptokurtic) than those of cycle 2 (platykurtic).

\section{Mineralogical Analysis}

The sandstones of the Simpson Group are classified as arenites (Folk, 1968) and consist mainly of detrital framework grains and cement. Detrital clay matrix is rare; authigenic clays sometimes occur as pore-filling cements. Quartzarenite (82 percent) is the most abundant sandstone type, and sublitharenite (14 percent) and subarkose ( 4 percent) are the least common (fig. 11).

\section{Detrital Framework Composition}

The average detrital framework composition of the sandstones is 97.2 percent quartz, 1.5 percent feldspar, 


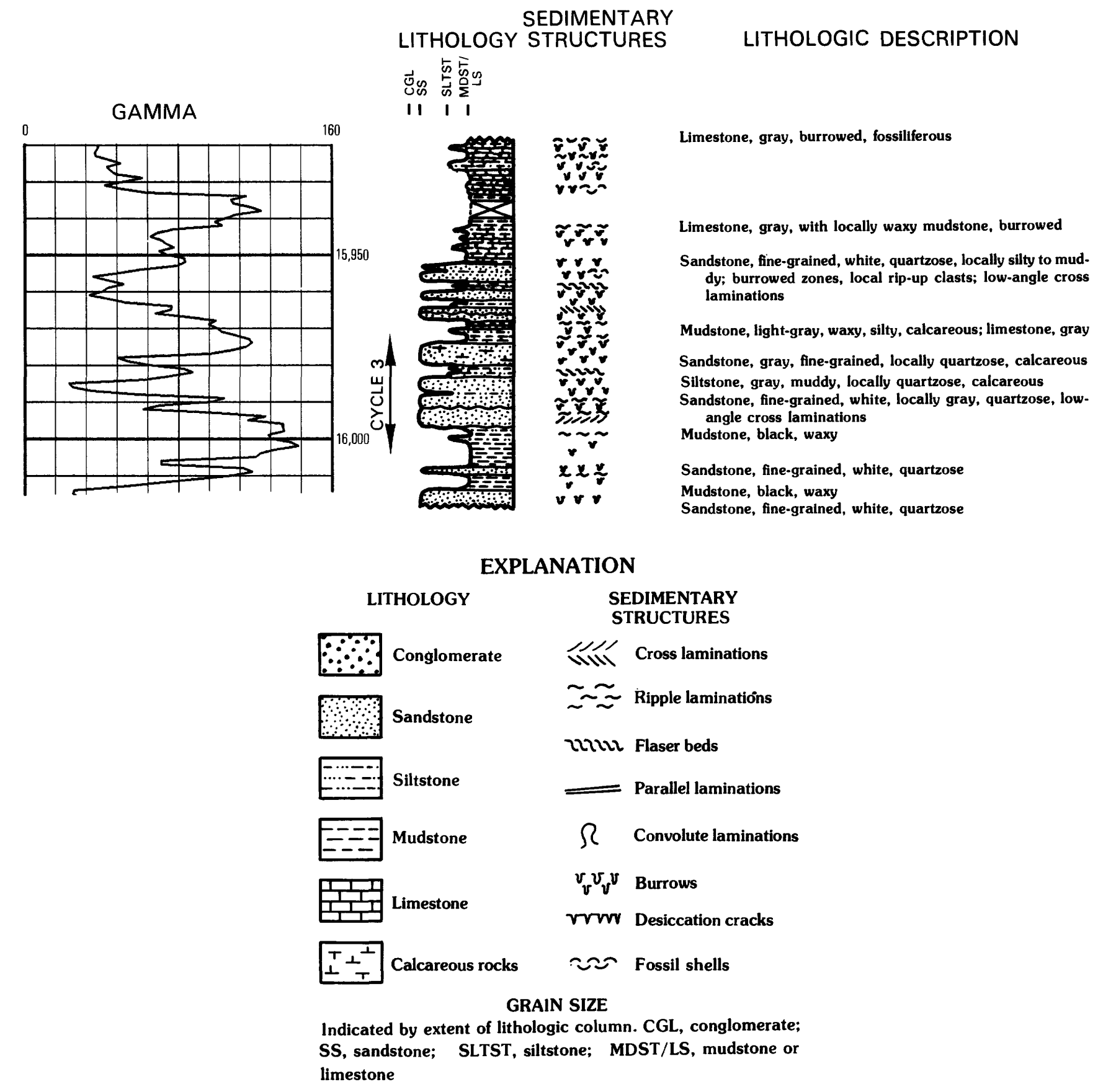

Figure 8. Gamma-ray and lithologic logs for cycle 3, upper member of Bromide Formation, Mazur well. Depth below surface (in feet) shown.

and 1.3 percent rock fragments. Quartz includes monocrystalline and polycrystalline grains (appendix 3-5). Monocrystalline quartz, which exhibits straight to undulose extinction, is the most dominant constituent, ranging from 79 to 99 percent. Polycrystalline quartz is a minor constituent, ranging from 0 to 16 percent.

Feldspar rarely exceeds 4 volume percent and is composed of potassium feldspar (as much as 8 volume percent) consisting of orthoclase, microcline, and perthite. Orthoclase is the most common potassium feldspar; some grains have been altered to kaolinite. Plagioclase is rare and does not exceed 1 volume percent.

Rock fragments rarely exceed 12 volume percent and consist of chert, micaceous rock fragments, siltstone, shale, limestone, glauconite, collophane, and skeletal fossil fragments (crinoids, brachiopods, echinoderms, and bryozoans). Chert is the most common rock fragment (as much as 12 volume percent) (appendix 3-6, 3-7). Siltstone and shale fragments rarely occur in amounts greater than 1 percent. 


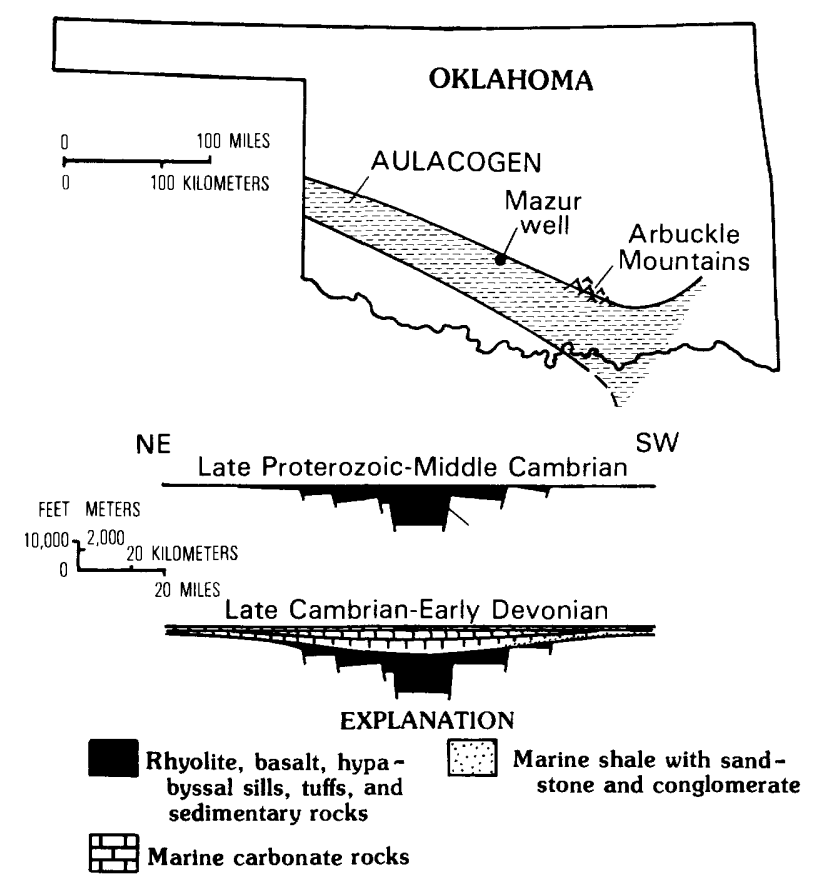

Figure 9. Location of Mazur well in relation to aulacogen (patterned area) that existed in southern Oklahoma from Late Cambrian to Early Devonian time. Schematic cross sections for two periods of time drawn through area of well are also shown.

Accessory minerals occur in amounts less than 0.5 percent and include brown tourmaline, zircon, and hornblende. Opaque minerals include magnetite-ilmenite and leucoxene.

Visual comparison of the detrital framework composition of the sandstones (table 2) suggests some differences between sandstones of cycles 1,2 , and 3 . The sandstones of cycle 1 contain the least quartz (95.6 percent average) as compared to sandstones of cycles 2 and 3, which may average as much as 99.8 percent. The sandstones of cycle 1 contain more feldspar (2.6 percent average) and rock fragments (1.8 percent average) than sandstones of cycles 2 and 3 , which on average contain only 0.2-0.3 percent feldspar and no rock fragments.

\section{Cement}

Several types of cement are in the sandstones: silica (18 volume percent), carbonate (15 volume percent), and clay (3 volume percent). Authigenic silica cement in the form of syntaxial quartz overgrowths (appendix 3-8) is very common (as much as 37 volume percent). Many of the overgrowths are separated from their host grains by thin dust rims. Some overgrowths lack dust rims but can be identified by their euhedral outlines.

Authigenic carbonate cements include calcite, ferroan calcite, ferroan dolomite, and ankerite and may account for as much as $\mathbf{4 0}$ volume percent (individual sample) of the sandstone. Calcite (appendix 3-9) occurs
Table 1. Grain-size properties of sandstones of the Simpson Group, Mazur well

[Properties in $\phi ; 50$ measurements per thin section. Cycles shown in figure 5. Measurements from Folk (1968)]

\begin{tabular}{lccccc}
\hline & $\begin{array}{c}\text { Mean grain } \\
\text { size }\end{array}$ & Sorting & Skewness & Kurtosis & $\begin{array}{c}\text { Number of } \\
\text { thin sections }\end{array}$ \\
\hline Cycle 1 & 2.32 & 0.82 & 0.05 & 0.91 & 14 \\
Cycle 2 & 2.35 & .82 & .05 & .77 & 5 \\
Cycle 3 & 1.87 & 1.07 & .72 & 1.16 & 3 \\
Others & 2.22 & .96 & .04 & .78 & 7 \\
\hline
\end{tabular}

both as poikilotopic and equant, mosaic crystals. Bluestained ferroan dolomite/ankerite commonly occurs as zoned euhedral rhombs (appendix 3-10), which clearly indicate variations in the ferrous iron content of pore fluids. The dolomite/ankerite commonly occurs as a pore-filling cement. Many detrital quartz grains and chert rock fragments display corroded boundaries and partial replacement by carbonate cements (appendix 3-6).

Authigenic clay (appendix 3-11) is the least important cement and is in only about 25 percent of the samples. Where present, however, it accounts for as much as 23 volume percent of the sample. The clay is brown (in plane-polarized light) and appears to act as a pastelike, pore-filling cement (a pseudomatrix). The association of this clay with micaceous rock and clay-rich siltstone fragments indicates that the clays are alteration products of the rock fragments.

Cements in the sandstones of cycles 1,2, and 3 can be differentiated by the amounts of the quartz overgrowths, authigenic clays, and carbonate constituents. Quartz overgrowths are common (19.8-22 volume percent) in cycles 1 and 2; authigenic clay is most common (average 4.8 volume percent) in cycle 2 ; and carbonate cement is abundant (average 31.7 percent) in cycle 3 .

\section{Paragenetic Sequence}

The postdepositional and burial diagenetic history of the sandstones (fig. 12) may be summarized as: (1) introduction of detrital clay coatings, (2) precipitation of quartz overgrowths, and (3) precipitation of carbonate cements. Formation of primary clay (appendix 3-12) and (or) some hematite coatings on the detrital quartz grains is the earliest diagenetic event and may have occurred either during deposition of the sediments or during a very early stage of diagenesis. It was followed by early burial diagenesis, during which quartz overgrowths formed. Dust rims between the primary detrital quartz grains and quartz overgrowths suggest that the cement may have been derived from pressure solution (Heald, 1965) and probably from alteration of shales (Hower and others, 1976). 
Table 2. Mineral composition of sandstones of the Simpson Group, Mazur well [In percent; 100 points each per thin section for detrital framework grain constituents and for total rock constituents. Cycles shown in figure 5]

\begin{tabular}{|c|c|c|c|c|c|c|c|c|}
\hline & & & & \multicolumn{4}{|c|}{ Total rock constituents } & \multirow{3}{*}{$\begin{array}{l}\text { Number } \\
\text { of thin } \\
\text { sections }\end{array}$} \\
\hline & \multicolumn{3}{|c|}{ Detrital framework grains } & \multicolumn{4}{|c|}{ Cement } & \\
\hline & Quartz & Feldspar & $\begin{array}{c}\text { Rock } \\
\text { fragments }\end{array}$ & $\begin{array}{c}\text { Framework } \\
\text { grains }\end{array}$ & $\begin{array}{c}\text { Quartz } \\
\text { overgrowths }\end{array}$ & Carbonate & Clay & \\
\hline Cycle 1 sandstones & 95.6 & 2.6 & 1.8 & 65.6 & 22.0 & 12.0 & 0.4 & 14 \\
\hline Cycle 2 sandstones & 99.8 & .2 & 0 & 61.4 & 19.8 & 14.0 & 4.8 & 5 \\
\hline Cycle 3 sandstones & 99.7 & .3 & 0 & 59.3 & 9.0 & 31.7 & 0 & 3 \\
\hline Other sandstones & 97.8 & .5 & 1.7 & 65.5 & 5.5 & 23.8 & 5.2 & 7 \\
\hline All sandstones & 97.2 & 1.5 & 1.3 & 64.0 & 18.0 & 15.0 & 3.0 & 29 \\
\hline
\end{tabular}

Authigenic clay is an early diagenetic constituent that predates carbonate precipitation. It formed as porefilling cement binding detrital quartz grains, and its ductile appearance reflects early compaction during burial. It may have formed as the result of dissolution and recrystallization of clay-rich rock fragments and perhaps as the result of alteration of glauconite (AlShaieb and Walker, 1986).

Carbonate cementation occurred in three stages. The first stage consists of precipitation of mosaic and poikilotopic calcite, which replaced quartz overgrowths and grains and filled pores. The second stage is the replacement of early calcite cement by iron-bearing calcite and dolomite. The third stage includes precipitation of ferroan dolomite and ankerite as porefilling euhedral rhombs and replacement of early calcite cement. The source of carbonate is probably from pressure solution of skeletal fragments; however, where the sandstone is cemented by as much as 40 percent carbonate, the source of the carbonate remains an enigma.

Diagenetic events in the paragenetic sequence are not observed in all the sandstones. The most commonly recognized paragenetic sequences in sandstones of the cycles include the following.

\section{Porosity}

Much of the primary intergranular porosity of the sandstones has been destroyed by precipitation of quartz overgrowths, formation of authigenic clay, and carbonate cements. These cements occlude substantial amounts of primary porosity. Secondary porosity, formed by intergranular dissolution of quartz overgrowths and grains and dissolution of carbonate cement, ranges from a trace to slightly less than 10 percent. Where porosity is high, 75 average percent of the porosity is due to intergranular dissolution and the resulting pore space is interconnected. Dissolution is marked by jagged quartz boundaries (appendix 3-13). The highest porosity is in the uppermost $20 \mathrm{ft}$ of cycle 1 , where total porosity averages 4-5 percent. Total porosity of sandstones of cycles 2 and 3 varies from a trace to less than 1 percent (appendix 3-6).

The mechanisms of development of secondary porosity in the sandstones have been discussed by Schmidt and McDonald (1979), Larese and others (1984), and Loucks and others (1984), who emphasized the importance of $\mathrm{CO}_{2}$ in leaching detrital and authigenic constituents of the sandstones. The $\mathrm{CO}_{2}$ is produced by decarboxylation of organic acids during thermal maturation of shales. Surdam and others (1984) proposed that secondary porosity may have been developed by organic acids produced during maturation of kerogen. We propose that development of secondary porosity in sandstones of the Simpson Group may be related to leaching fluids.

\section{Interpretation}

The lithofacies interpretation of the Simpson Group sandstones as tidal deposits is suggested by their petrography. Their mineralogical and textural maturity, as indicated by quartz contents of more than 95 percent and by well-developed sorting and roundness, reflects vigorous winnowing and (or) a mineralogically mature source. The environment in tidal-influenced coasts is characterized by intensive physical and chemical breakdown of immature mineral grains.

Minor differences in the quartz, feldspar, and rock fragments contents of sandstones of cycles 1,2 , and 3 may represent either derivation of the sediments from the same source area and (or) rocks or the distance of transport. The high quartz content may indicate sedimentary source rocks in which the quartz detritus was recycled; it may also be a function of the distance of transport of the sediments in which immature minerals are reworked and selectively removed from the sediment load by physical and chemical weathering. Early workers 

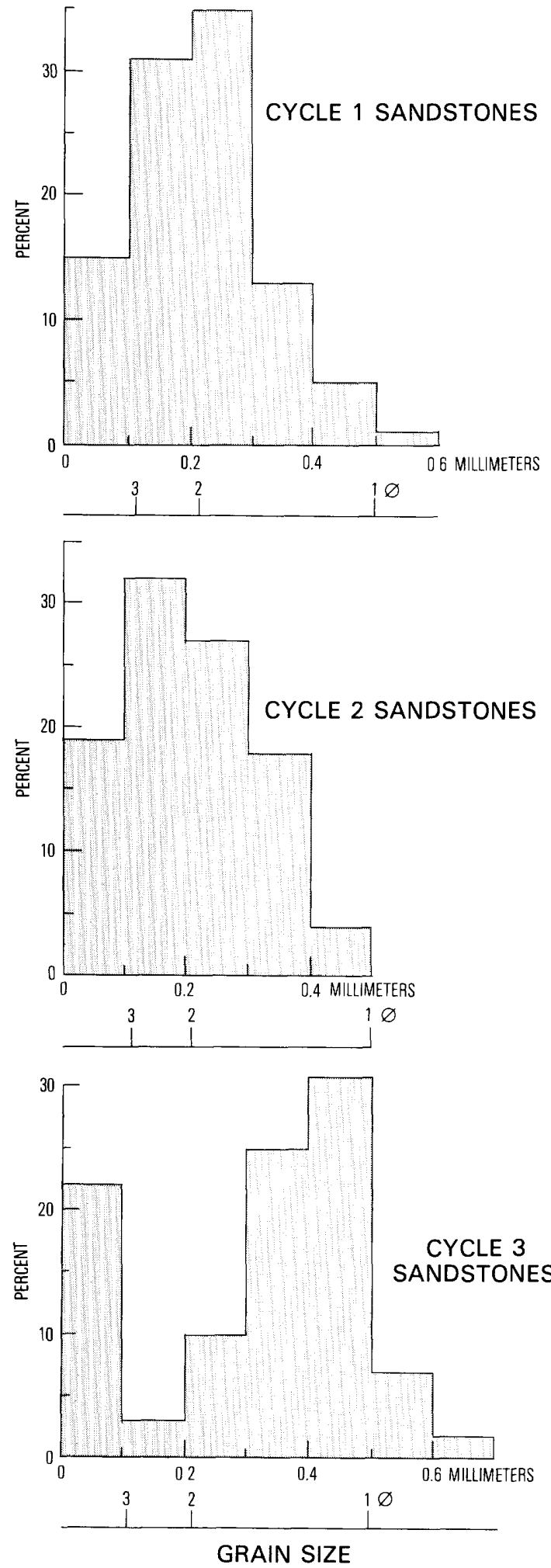

Figure 10. Frequency histograms of quartz grains in sandstones of cycles 1,2, and 3, Mazur well.

(Drake, 1921; Dapples, 1955; Schramm, 1964) postulated that the Simpson Group sediments were derived from the Canadian Shield, a distance of

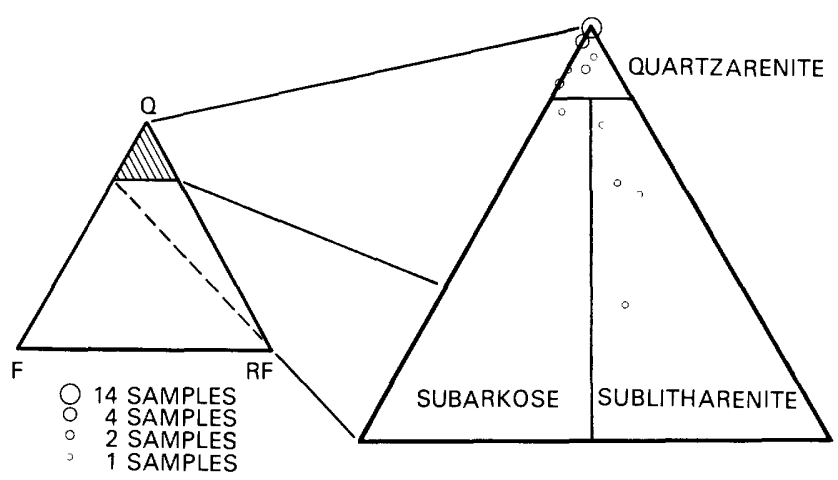

Figure 11. Quartz (Q)-feldspar (F)-total rock fragments (RF) ternary diagram showing major mineral composition and classification of sandstones from the Mazur well.

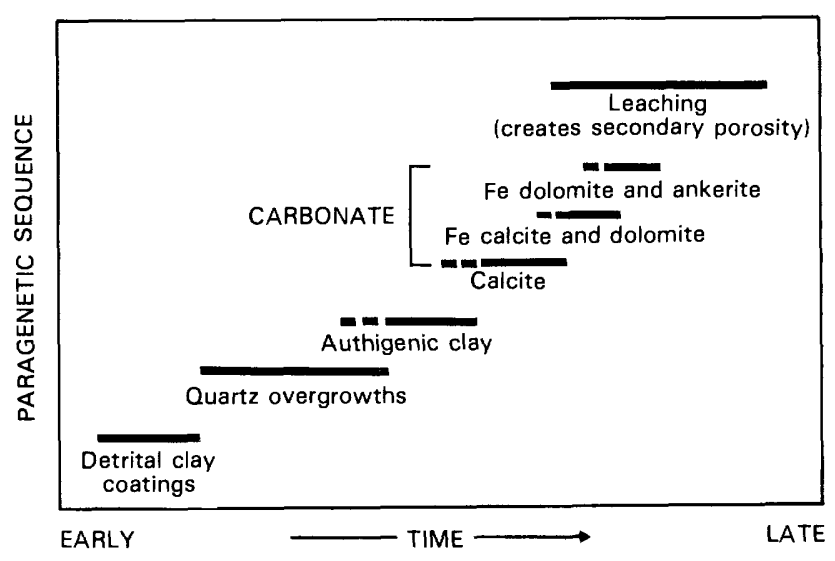

Figure 12. Postdepositional and burial diagenetic history of sandstones from the Mazur well.

900-1,000 mi from the site of deposition, and they proposed long-distance transport by eolian processes and (or) longshore currents. These hypotheses cannot be confirmed or denied by this study. The concept of recycled sedimentary rocks as possible provenance cannot be voided by the rare occurrence of secondary dust rims on detrital quartz grains. A tidal origin for the maturity of the sandstones is here suggested as another working hypothesis.

Regardless of the problems of provenance and mode and distance of transport of the sediments, evidence of vigorous energy at the site of deposition is provided by removal of substantial quantities of labile minerals, extensive abrasion, and concentration of uniform grain sizes. The lack of detrital matrix also represents the effect of lag concentrates, in which fine detritus is selectively eroded, leaving only coarser grains. This process of selective sorting is probably produced by repeated application of shearing forces such as those 
inherent to waxing and waning tidal currents. The bimodality of quartz grains of cycle 3 perhaps mimics differential size sorting during high- and low-tide oscillations. Distribution of lag concentrates toward the fine grains, as characterized by poorer sorting than beach environments (from well to moderate sorting) and by skewness of less than $1 \phi$, indicates a tidal-influenced, shallow-marine environment (Fuchtbauer, 1974, p. 60). Flushing out of the fine-grained matrix permits grainto-grain contacts and creates pore spaces that promote cementation during burial diagenesis.

\section{Summary}

Lithofacies and petrographic data compiled from a 650-ft-thick core of the Middle Ordovician Simpson Group in the Mazur well show that the southeastern part of the Anadarko basin in Oklahoma was a tidalinfluenced coast. Sediments of the McLish, Tulip Creek, and Bromide Formations were deposited in a subsiding basin as cyclical lithofacies sequences containing a lower subtidal-intertidal mudstone, siltstone, and limestone lithofacies and an upper tidal-channel sandstone lithofacies.

The sandstone lithofacies consists mainly of quartzarenites that contain as much as 99 percent quartz, 4 percent feldspar, and 12 percent rock fragments. The quartzarenites are fine to medium grained, exhibit well to moderate sorting, and have skewness of less than $1 \phi$, all of which typify sediments formed in tidal-influenced shallow-marine environment.

The sandstones are composed of silica, carbonate, and clay cements and have a paragenetic history characterized by initial development of detrital clay coatings on the quartz grains, succeeded by precipitation of quartz overgrowths, and then formation of carbonates. The carbonate cement, a late diagenetic constituent, formed in three stages: precipitation of calcite that replaced quartz overgrowths and grains and filled pore spaces, replacement of early calcite by ferroan calcite and dolomite, and precipitation of ferroan dolomite and ankerite as pore fillings and replacement of early calcite. Although these cements destroyed primary porosity of the sandstones, secondary porosity developed by dissolution of the cements and grains.

\section{REFERENCES CITED}

Al-Shaieb, Zuhair, and Walker, Patty, 1986, Evolution of secondary porosity in the Pennsylvanian Morrow sandstones, Anadarko Basin, Oklahoma, in Spencer, C.W., and Mast, R.F., eds., Geology of tight gas reservoirs: American Association of Petroleum Geologists Studies in Geology 24, p. 45-68.
Borras, J.B., 1979, Genetic study of the northwest Butterly field, Garvin County, Oklahoma: The Shale Shaker, v. 30, no. 3 , p. 58-76.

Dapples, E.C., 1955, General lithofacies relationship of St. Peter sandstone and Simpson Group: American Association of Petroleum Geologists Bulletin, v. 39, p. 444-467.

de Mowbray, T., and Visser, M.J., 1984, Reactivation surfaces in subtidal channel deposits, Oosterschelde, southwest Netherlands: Journal of Sedimentary Petrology, v. 54, p. 811-824.

Drake, C.L., 1921, The problem of the St. Peter sandstone: University of Missouri, School of Mines and Metallurgy Bulletin, v. 6, 224 p.

Folk, R.L., 1959, Practical petrographic classification of limestones: American Association of Petroleum Geologists Bulletin 43, p. 1-38.

1968, Petrology of sedimentary rocks: Austin, Tex., Hemphill, $170 \mathrm{p}$.

Fuchtbauer, H., 1974, Sediments and sedimentary rocks: New York, John Wiley, $464 \mathrm{p}$.

Hayes, M.O., and Kana, T.W., 1977, Terrigenous clastic depositional environments: Technical Report No. 11CRD, University of South Carolina, Columbia, $184 \mathrm{p}$.

Ham, W.E., 1969, Regional geology of the Arbuckle Mountains, Oklahoma: Oklahoma Geological Survey Guidebook 17, 52 p.

Heald, M.T., 1965, Lithification of sandstones in West Virginia: West Virginia Geological and Economic Survey Bulletin, v. $30,28 \mathrm{p}$.

Hoffman, Paul, Dewey, J.F., and Burke, K., 1974, Aulacogens and their genetic relation to geosynclines, with a Proterozoic example from Great Slave Lake, Canada: Society of Economic Paleontologists and Mineralogists Special Publication 19, p. 38-55.

Hower, J., Eslinger, E., Hower, M.E., and Perry, E.A., 1976, Mechanism of burial metamorphism of argillaceous sediments-1, Mineralogical and chemical evidence: Geological Society of America Bulletin, v. 87, p. 725-737.

Johnson, K.S., Burchfield, M.R., and Harrison, W.E., 1984, Guidebook for Arbuckle Mountain field trip, southern Oklahoma: Oklahoma Geological Survey Special Publication 84-1, 21 p.

Kennedy, C.L., ed., 1983, The deep Anadarko Basin: Denver, Colo., Petroleum Information Corporation, 359 p.

Kumar, N., and Sanders, J.E., 1975, Inlet sequence formed by migration of Fire Island Inlet, Long Island, New York, in Ginsburg, R.N., ed., Tidal deposits: New York, SpringerVerlag, p. 75-84.

Larese, R.E., Haskel, N.L., Prezbindowski, D.R., and Beju, Dan, 1983, Porosity development in selected Jurassic sandstone specimens from the Norwegian and North seas, Norway - an overview, in Petroleum geology of the North European margin: London, Graham and Trotman, p. 81-95.

Longman, M.W., 1981, Deposition of the Bromide Formation, Arbuckle Mountains, Oklahoma; ontogeny of an ancient carbonate shelf: The Shale Shaker, Digest Y, v. 32, no. 2, p. 1-18. 
Loucks, R.G., Dodge, M.M., and Galloway, W.E., 1984, Regional controls on diagenesis and reservoir quality in lower Tertiary sandstones along the Texas Gulf coast: American Association of Petroleum Geologists Memoir 37, p. 15-45.

Reineck, H.E., and Singh, I.B., 1980, Depositional sedimentary environments: New York, Springer-Verlag, 549 p.

Schmidt, V., and McDonald, D.A., 1979, The role of secondary porosity development in the course of sandstone diagenesis: Society of Economic Paleontologists and Mineralogists Special Publication 26, p. 175-208.
Schramm, M.W., Jr., 1964, Paleogeologic and quantitative lithofacies analysis, Simpson Group, Oklahoma: American Association of Petroleum Geologists Bulletin, v. 48 , p. $1164-1195$.

Surdam, R.C., Boese, S.W., and Crossey, L.J., 1984, The chemistry of secondary porosity: American Association of Petroleum Geologists Memoir 37, p. 127-149.

Weber, S.J., 1987, Petrography and diagenesis of the McLish Formation, Simpson Group (Middle Ordovician), southeastern Anadarko Basin, Oklahoma: Stillwater, Oklahoma State University, M.S. thesis, 97 p. 

Appendixes 1-3 
Appendix 1. Photographs of core recovered from the McLish, Tulip Creek, and Bromide Formations of the Middle Ordovician Simpson Group in the Mazur well, 15,913-16,413 ft. See figure 5 for lithologic descriptions and appendix 2 for photographs of selected core intervals and (or) sedimentary features.

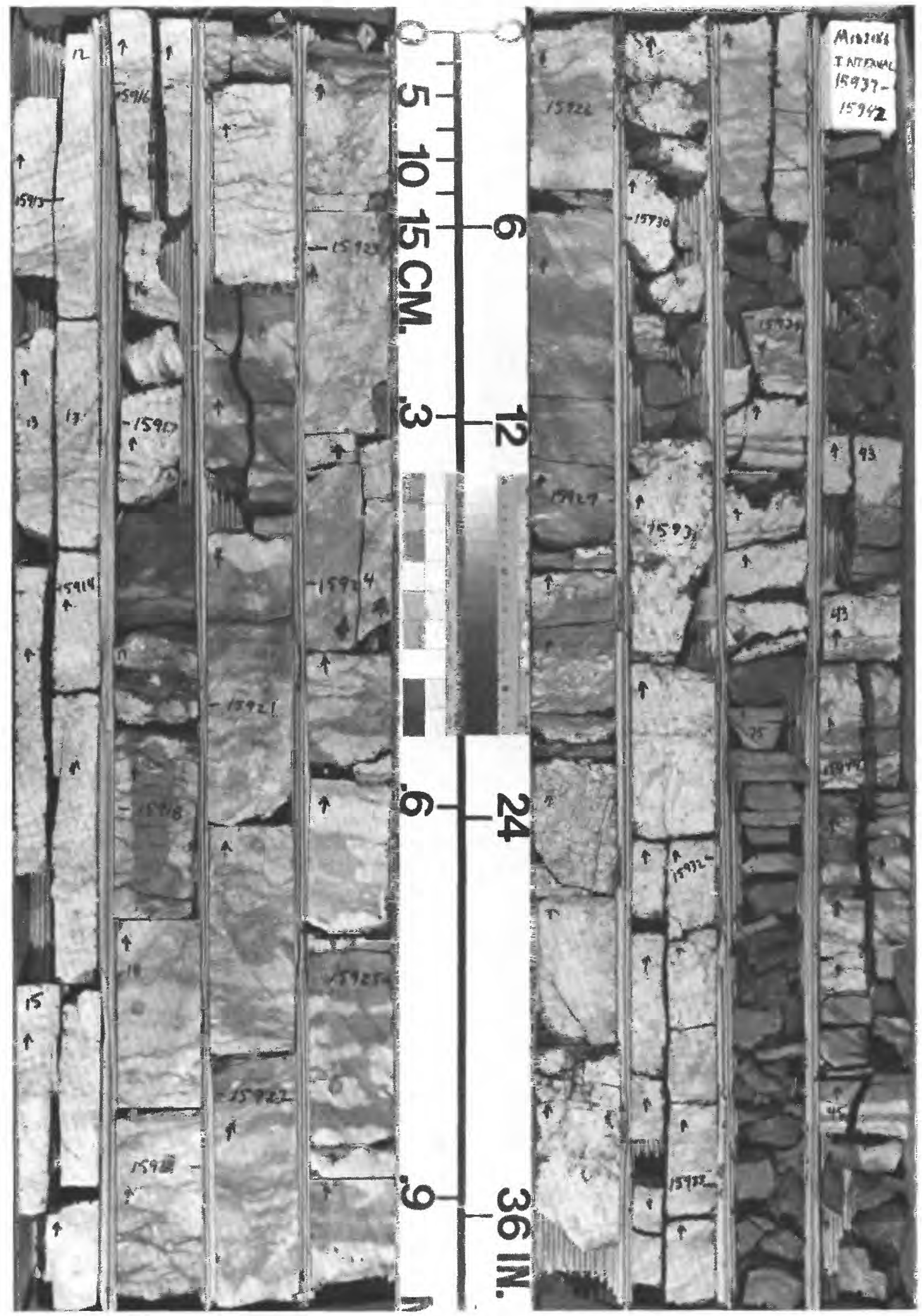




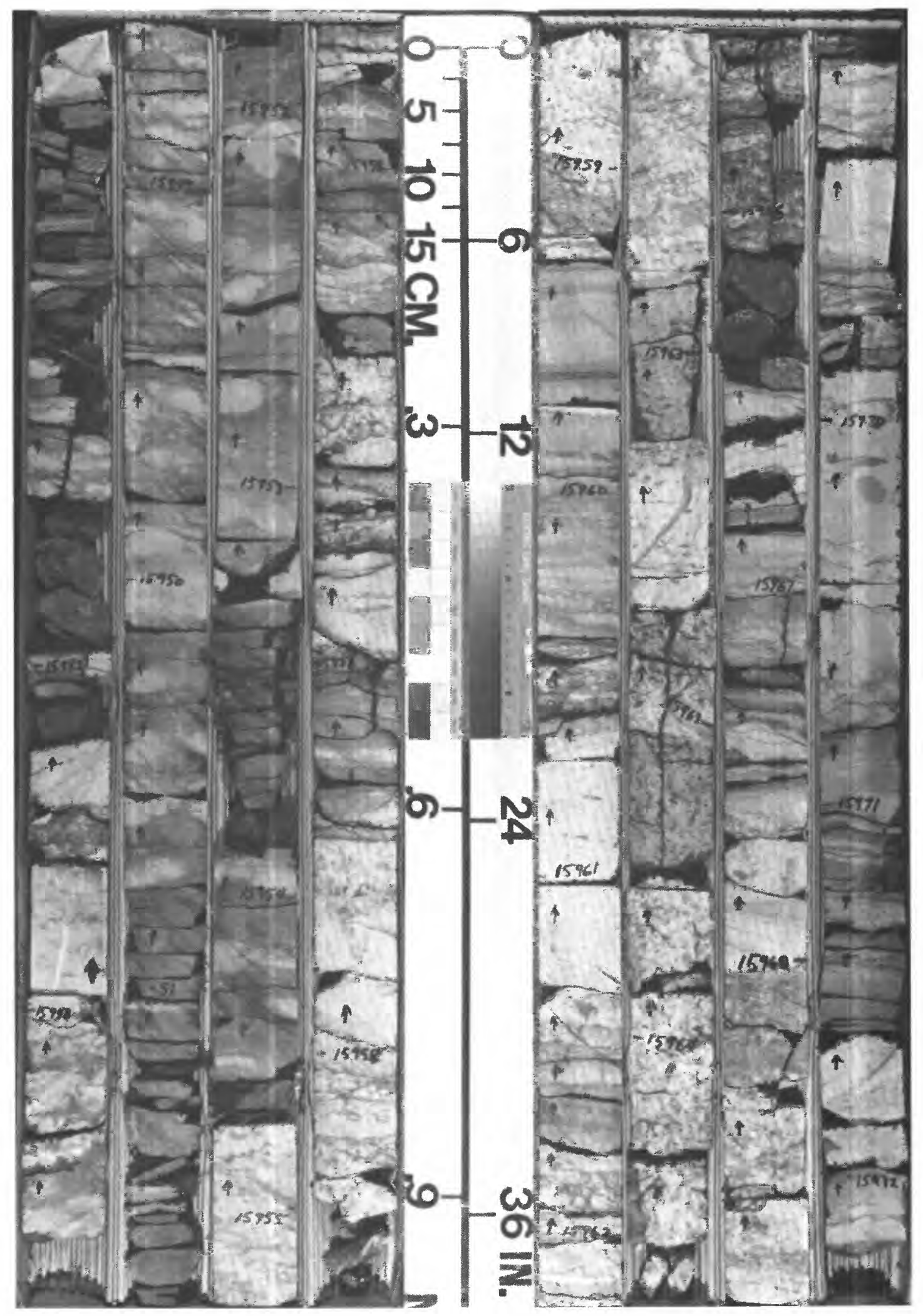




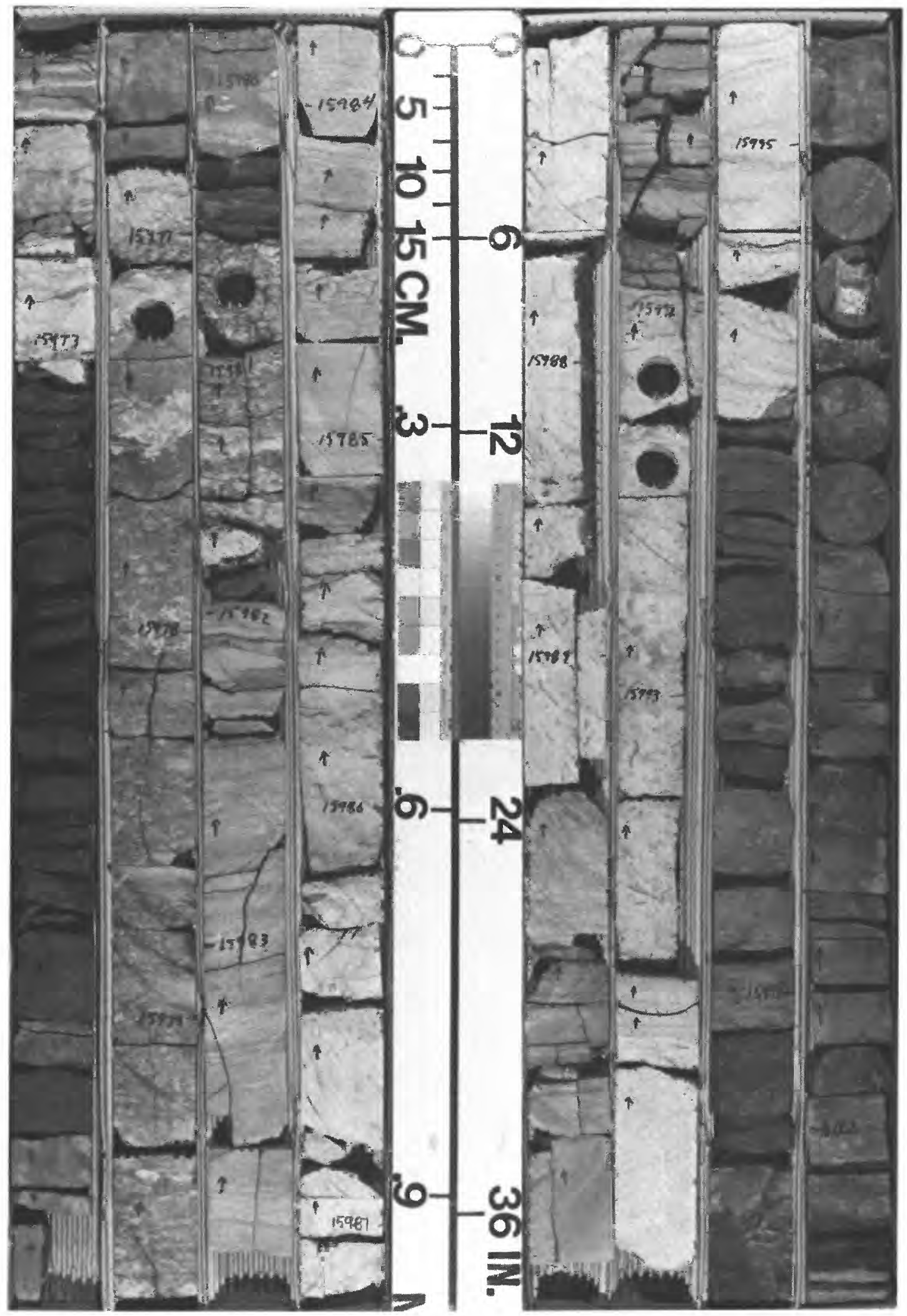




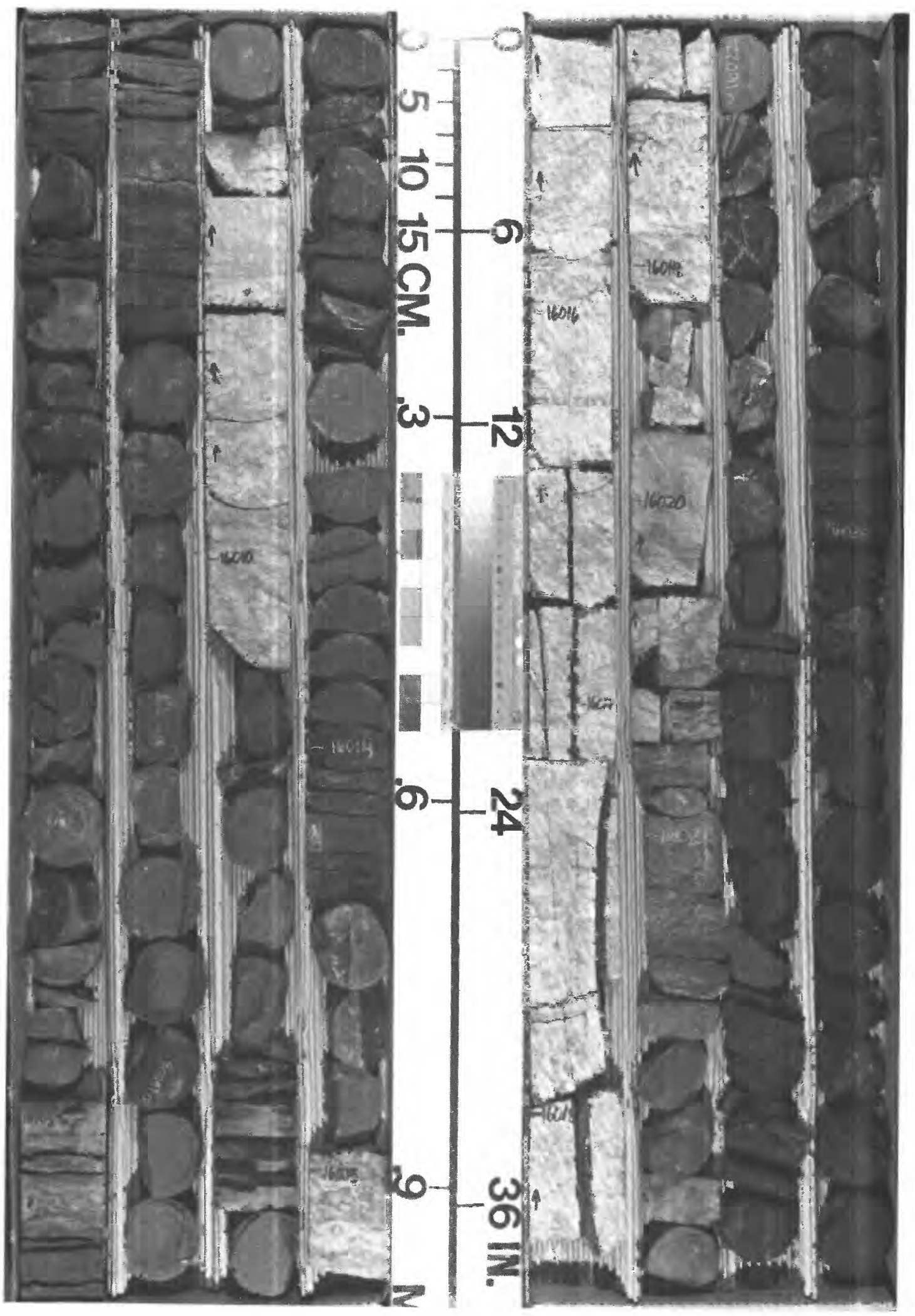




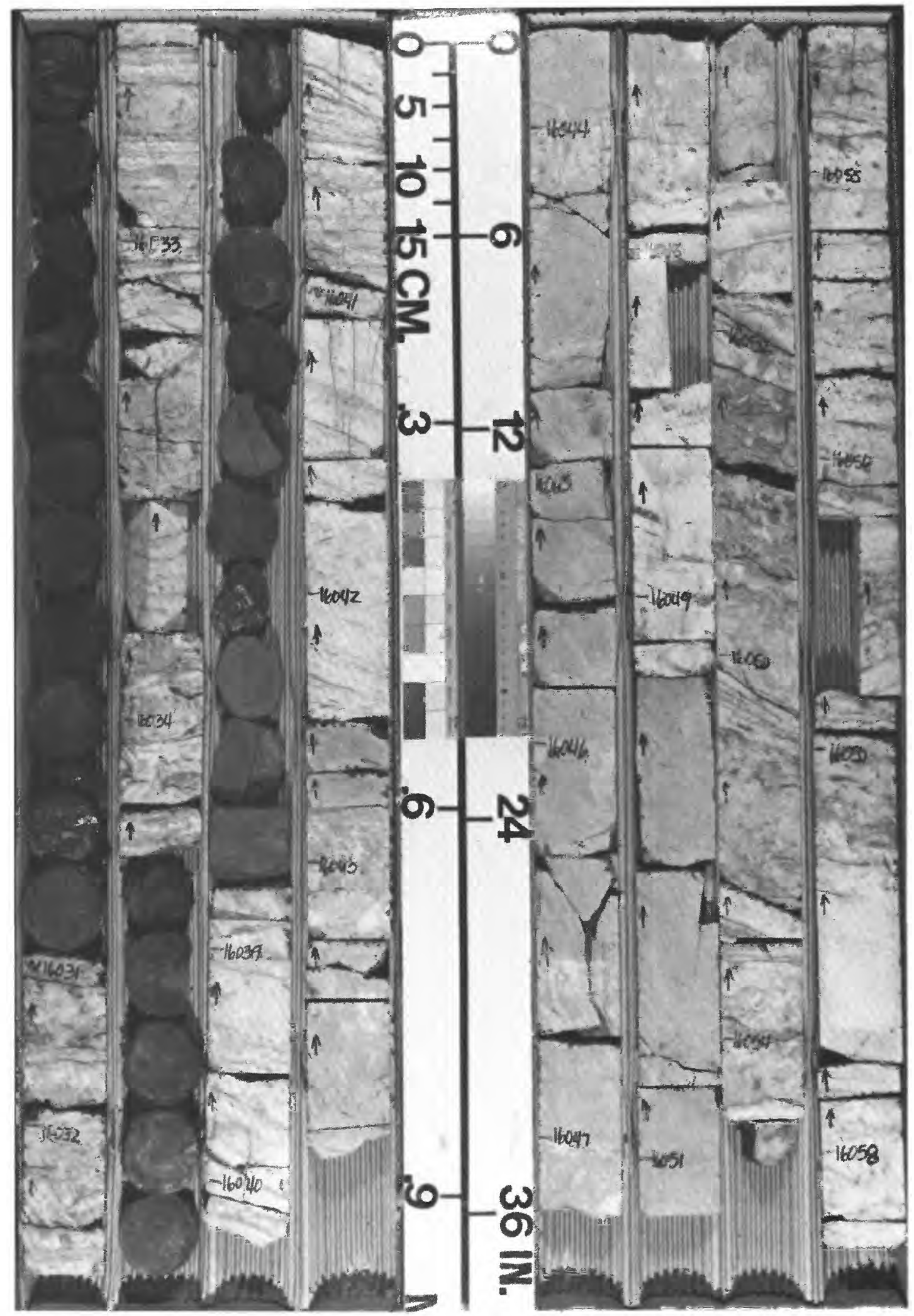




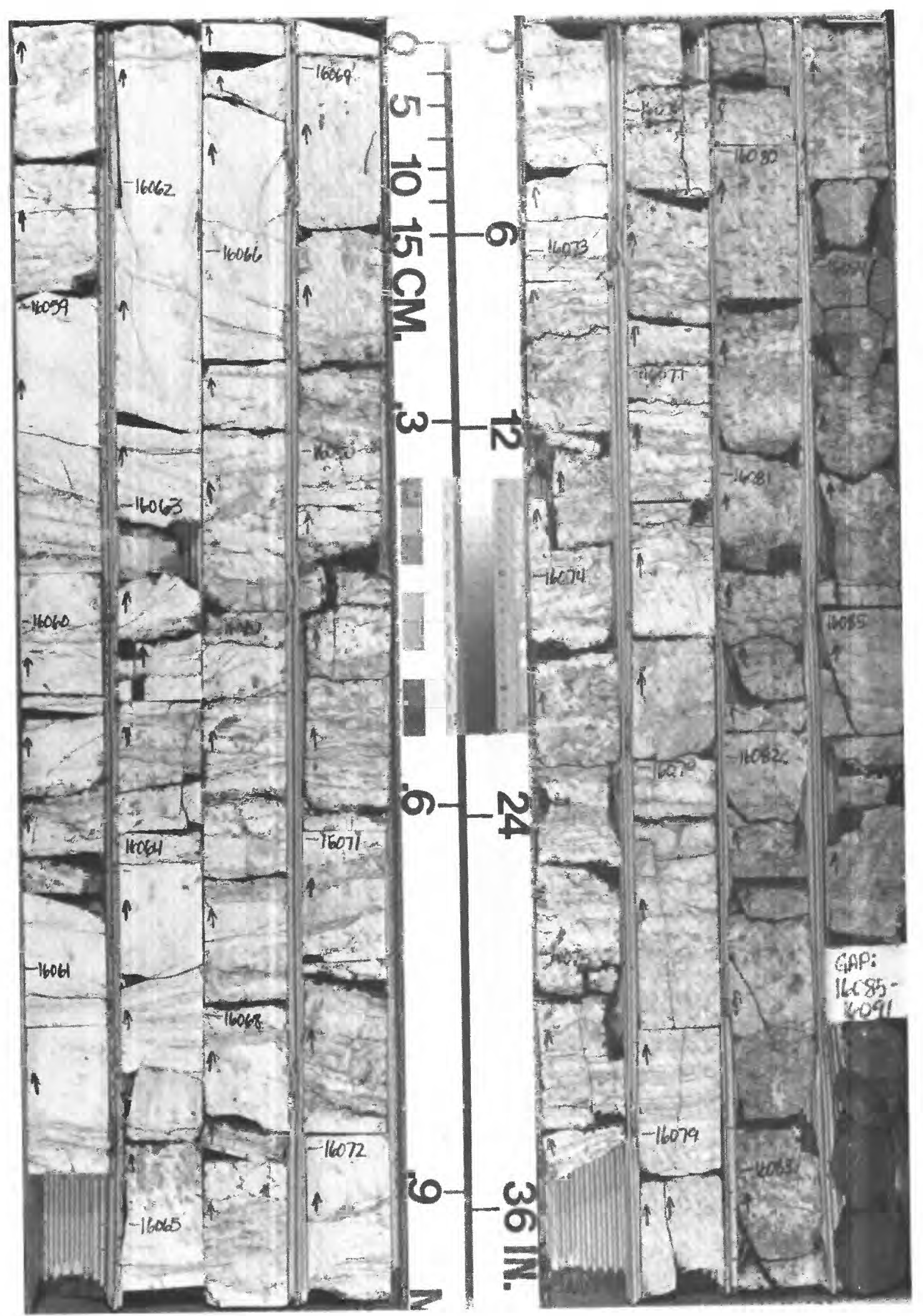




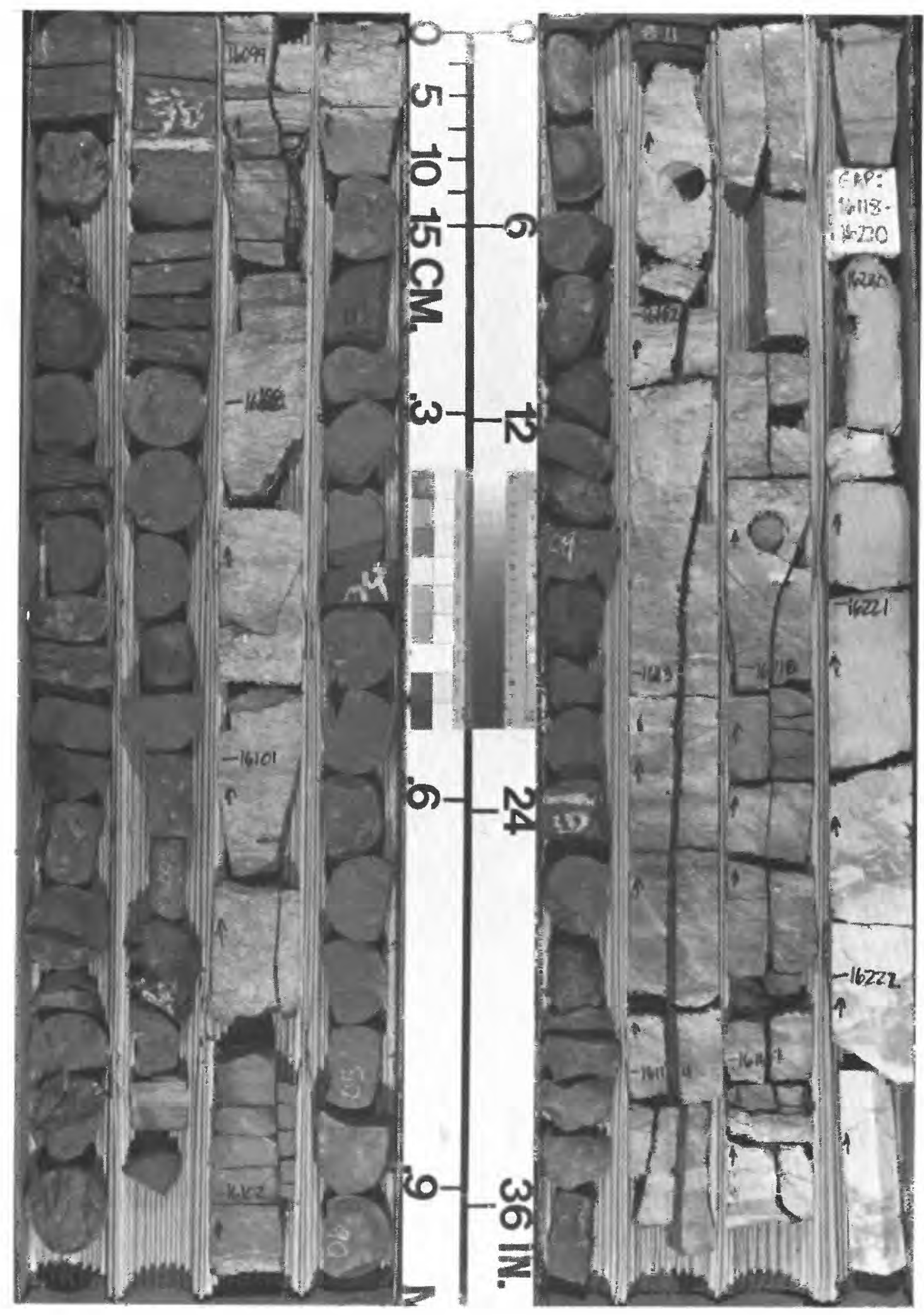




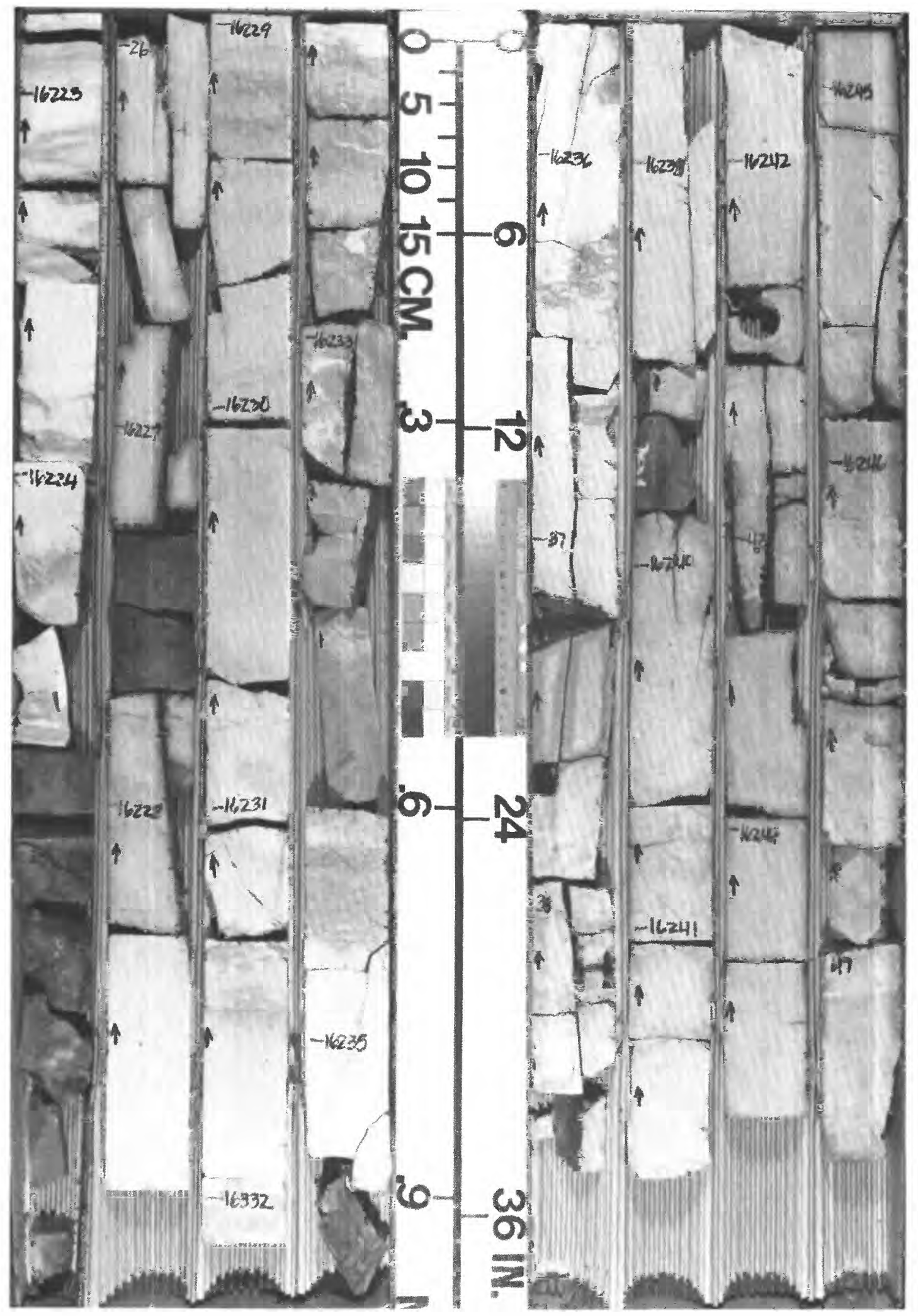




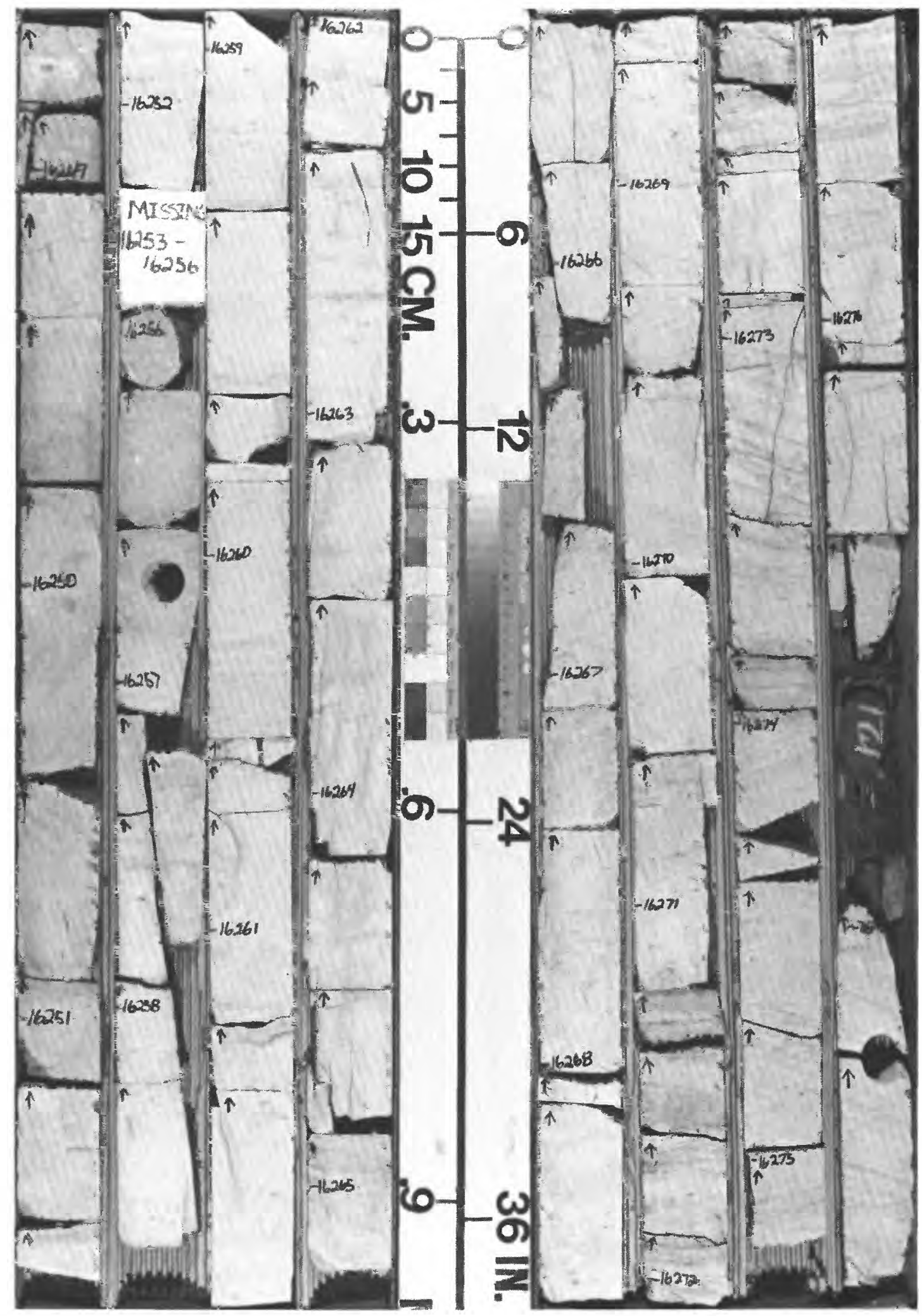




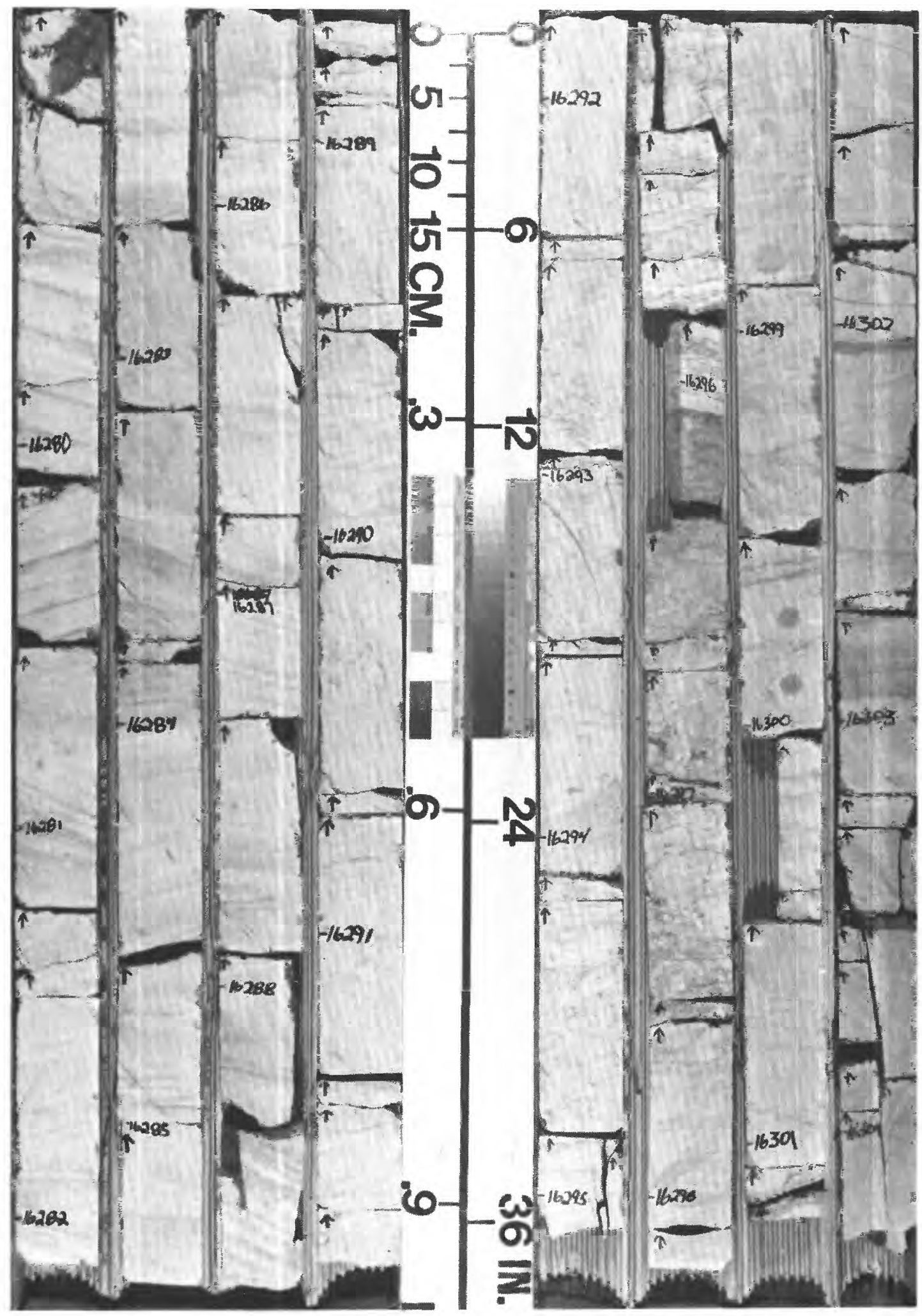




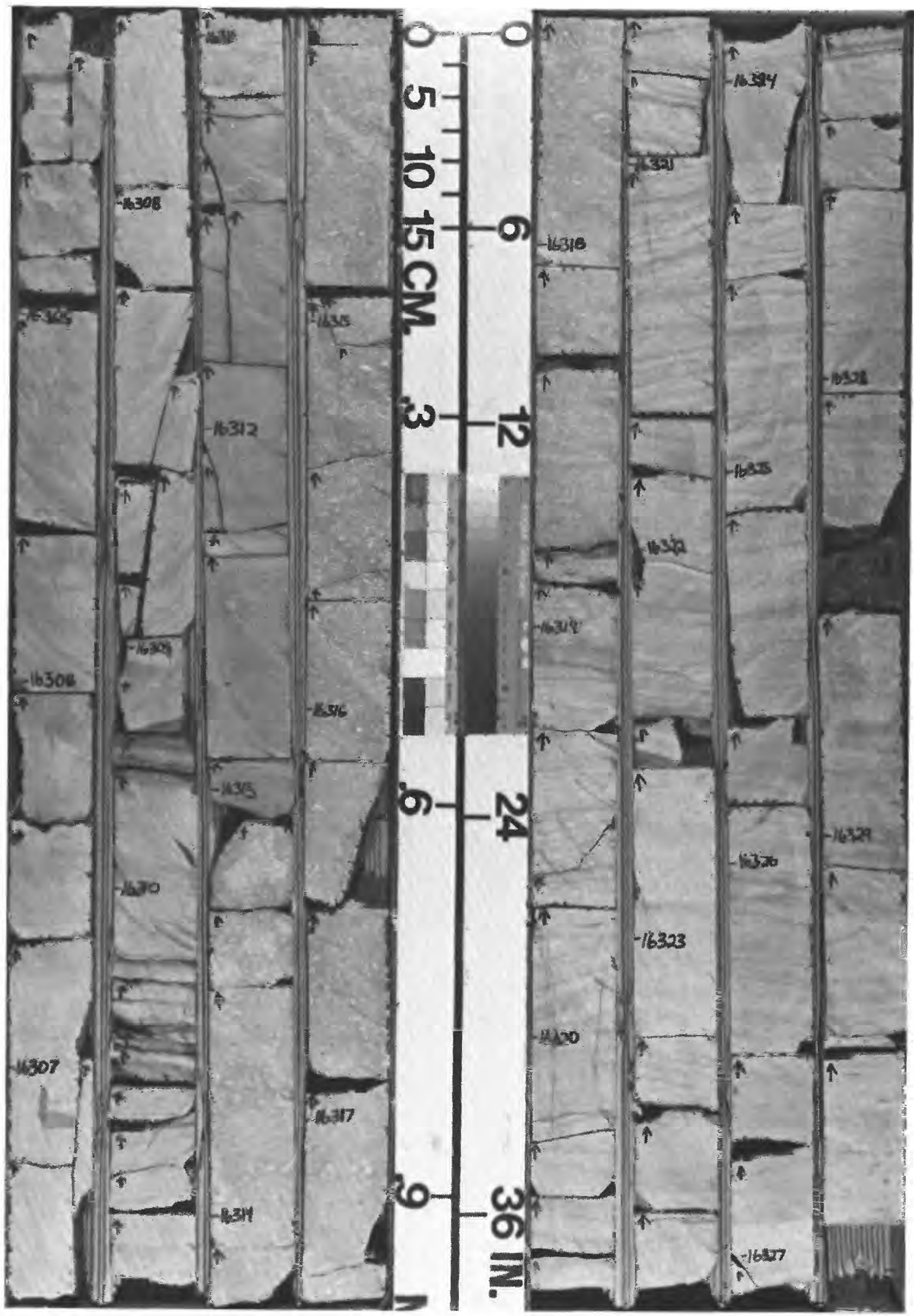




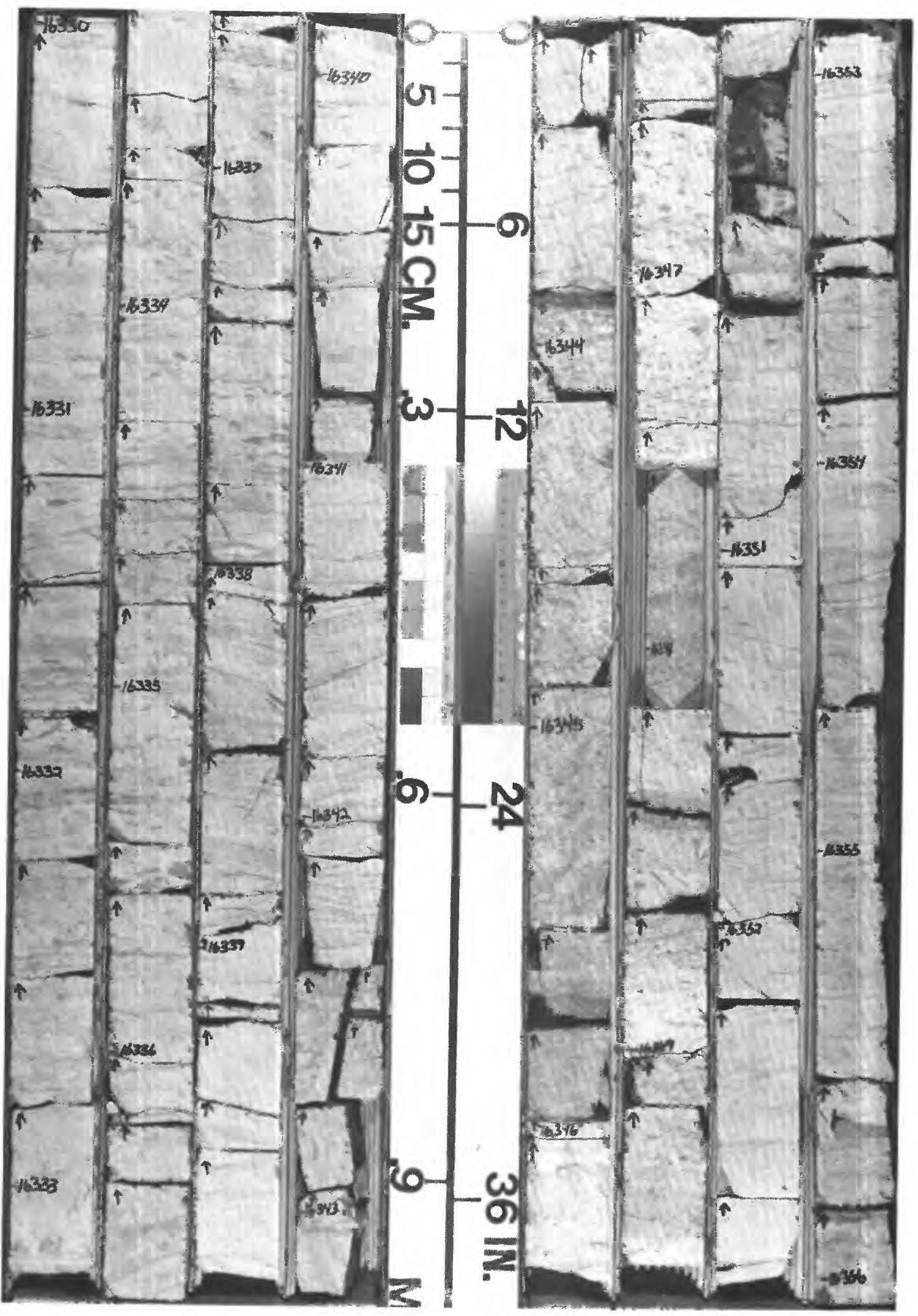




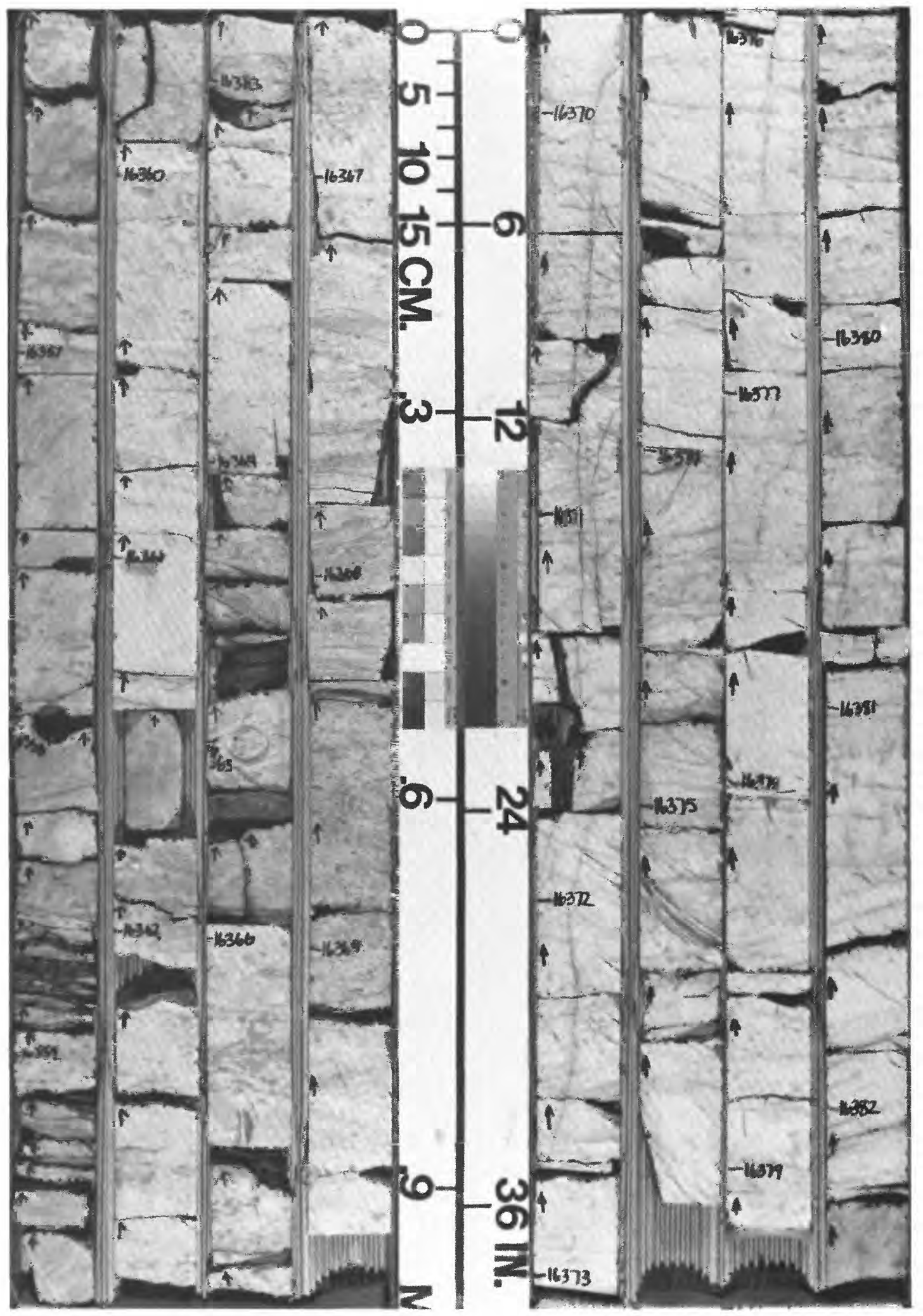




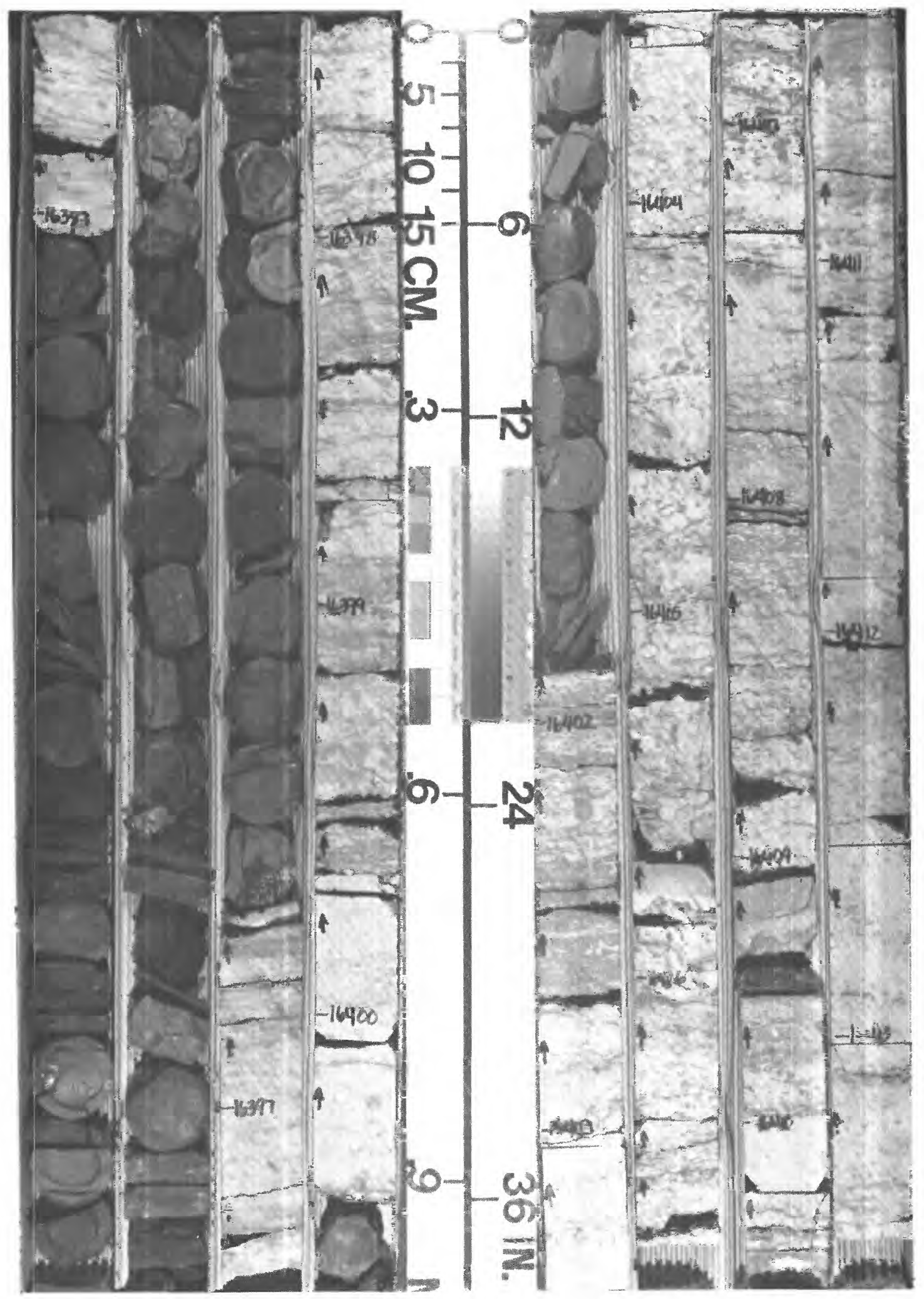


Appendix 2. Photographs of selected sedimentologic and (or) lithologic features in core from the Mazur well, McLish, Tulip Creek, and Bromide Formations of the Middle Ordovician Simpson Group. Centimeter scale shown.

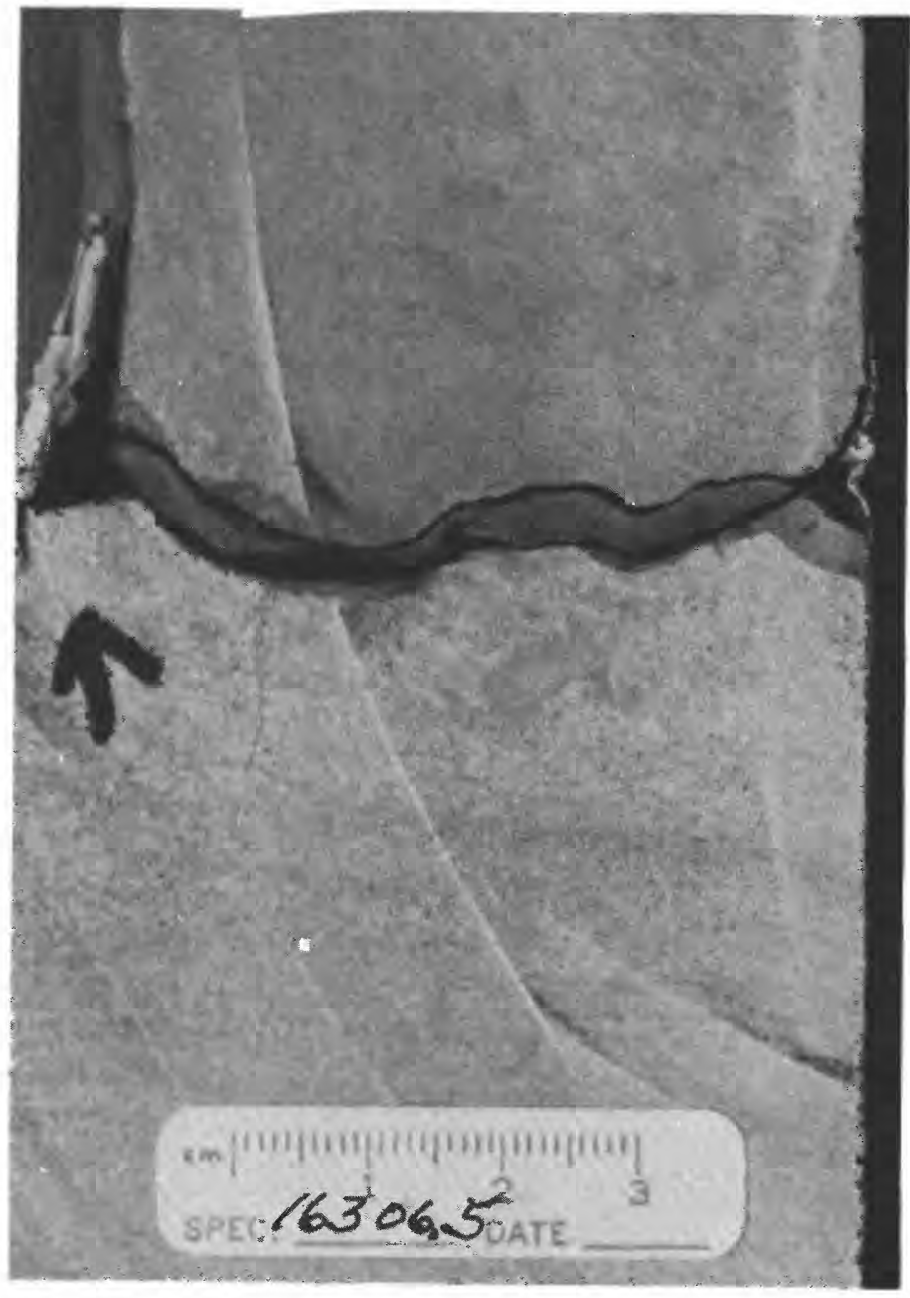

2-1. Erosional contact (siltstone clast?) in litharenite. Depth $16,306.5 \mathrm{ft}$.

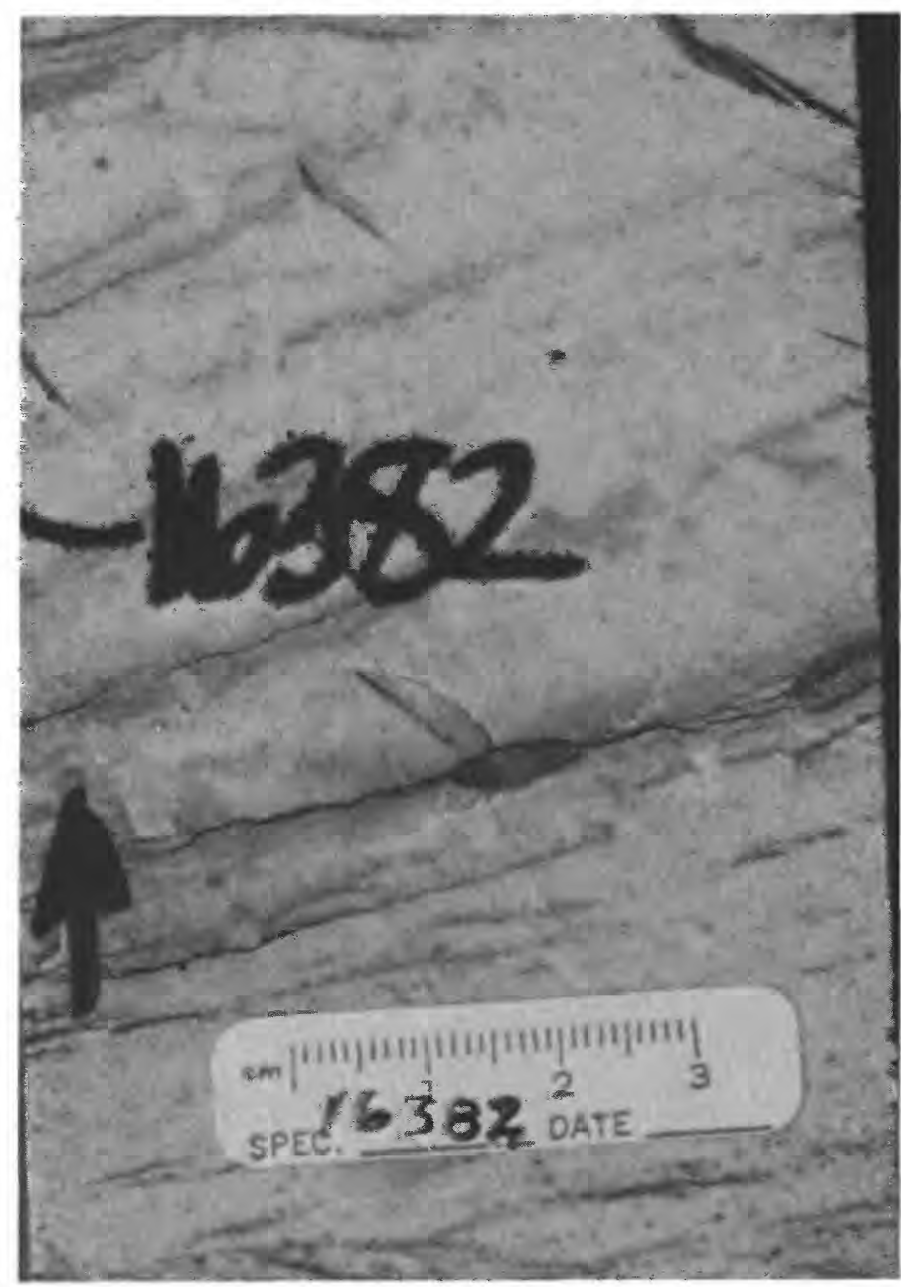

2-2. High-angle cross lamination in litharenite. Depth $16,382 \mathrm{ft}$. 


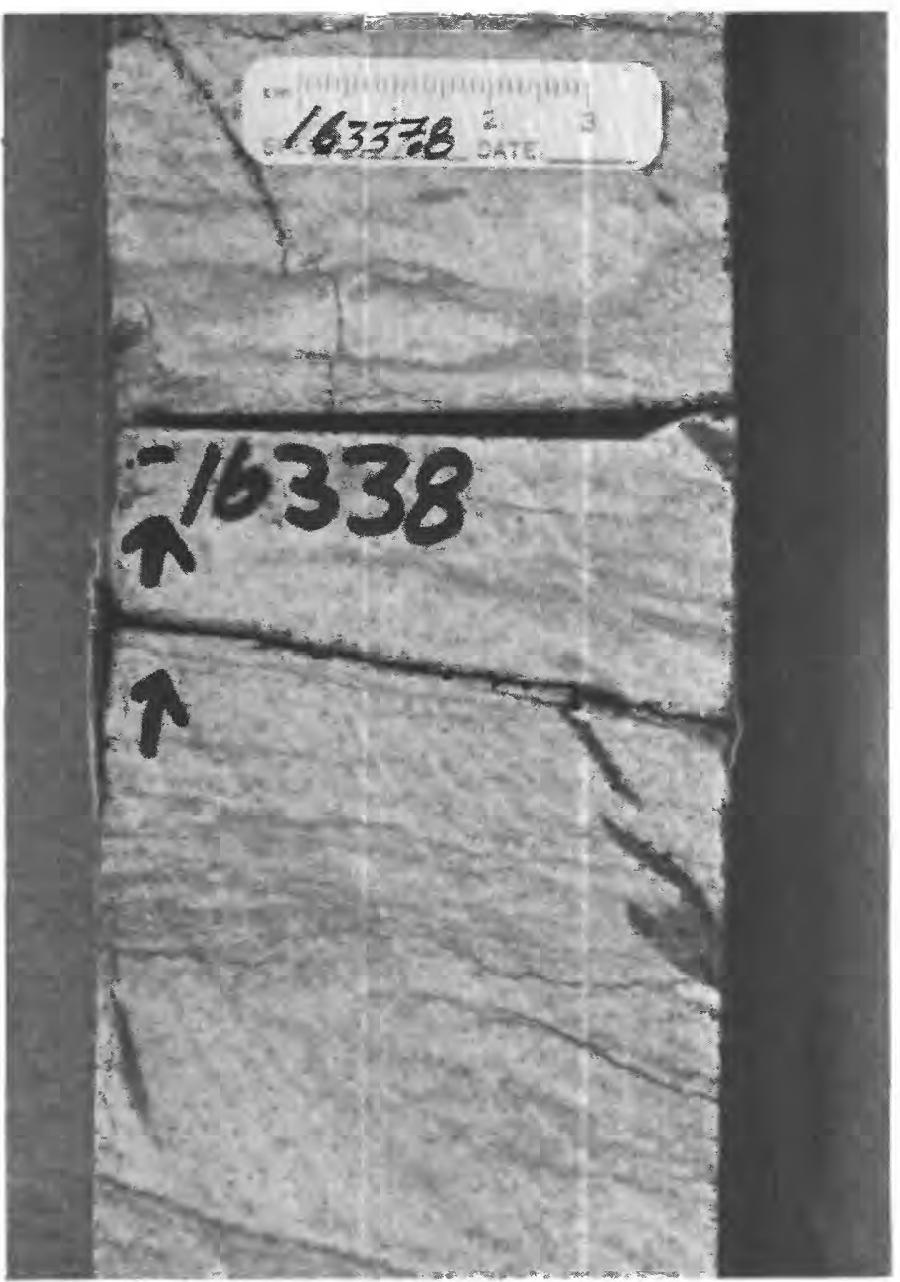

2-3. Low-angle cross laminations and ripple laminations in litharenite. Depth 16,337.8 ft.

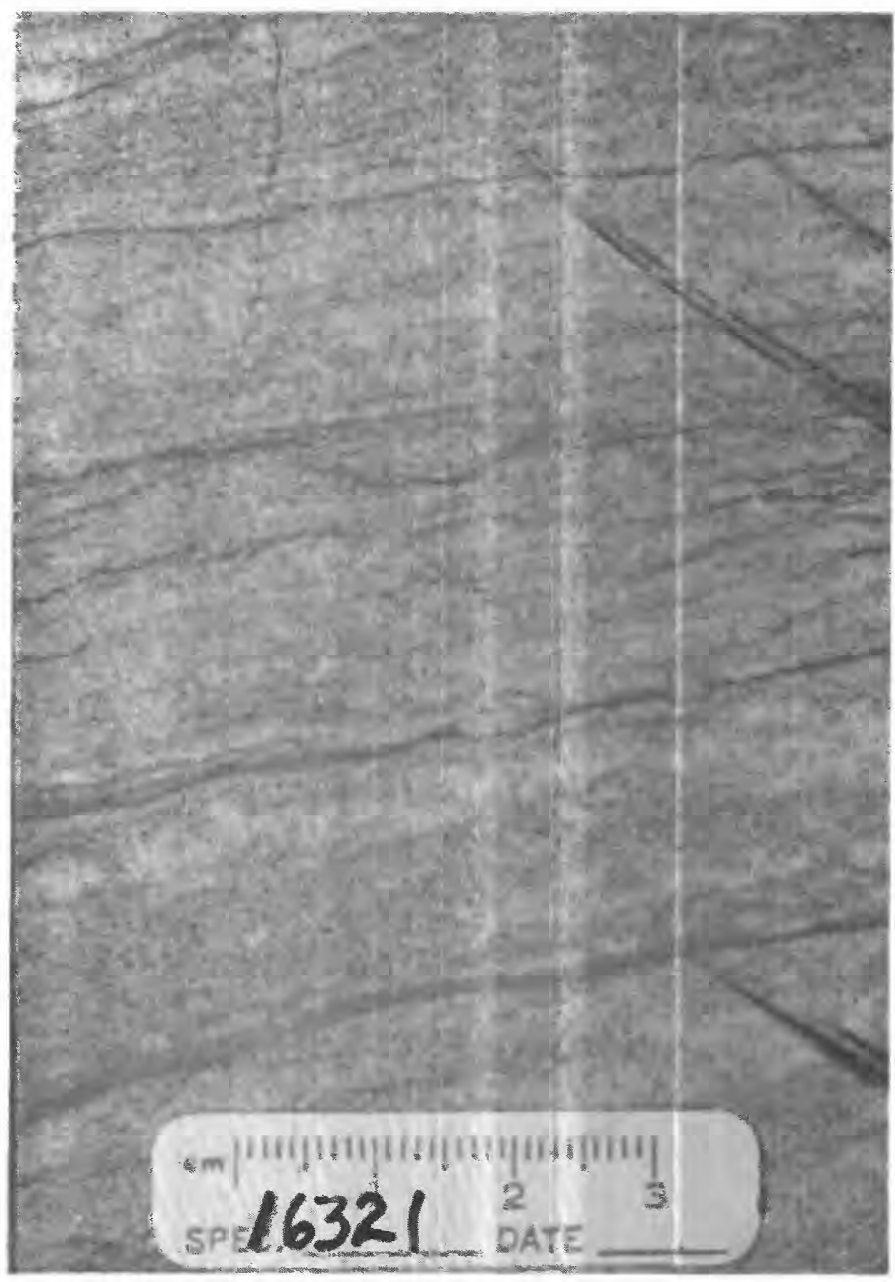

2-4. Ripple laminations in litharenite. Depth $16,321 \mathrm{ft}$. 


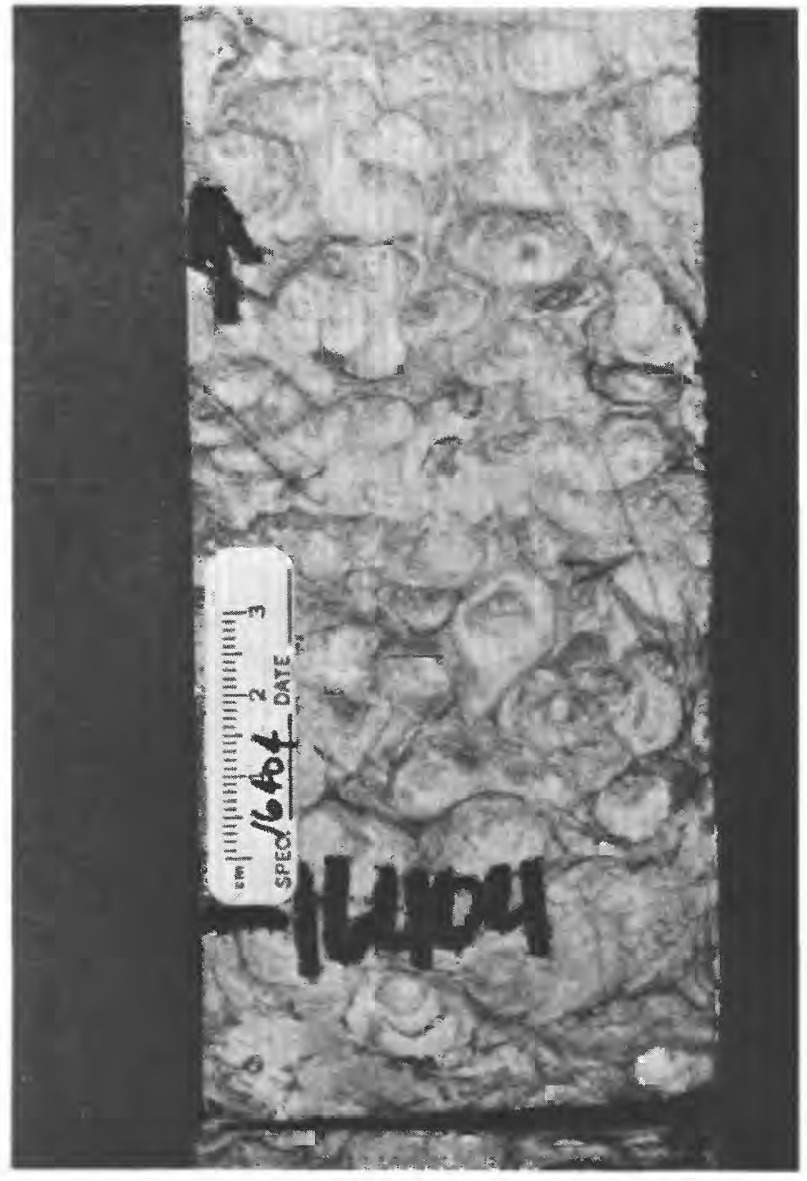

2-5. Intense bioturbation in sandstone. Depth $16,404 \mathrm{ft}$.

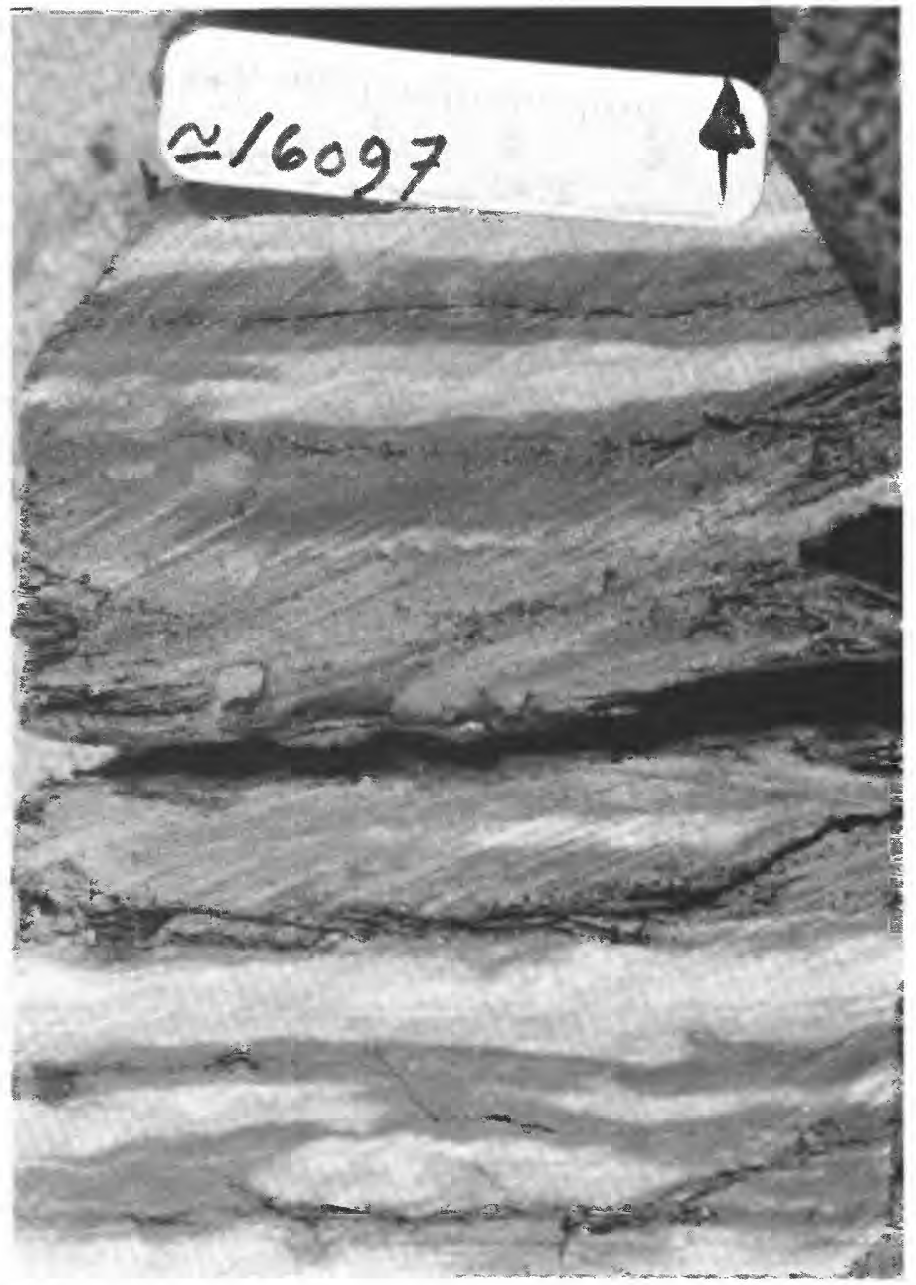

2-6. Interbedded white quartzose siltstone and gray siltstone. Depth 16, $097 \mathrm{ft}$. 


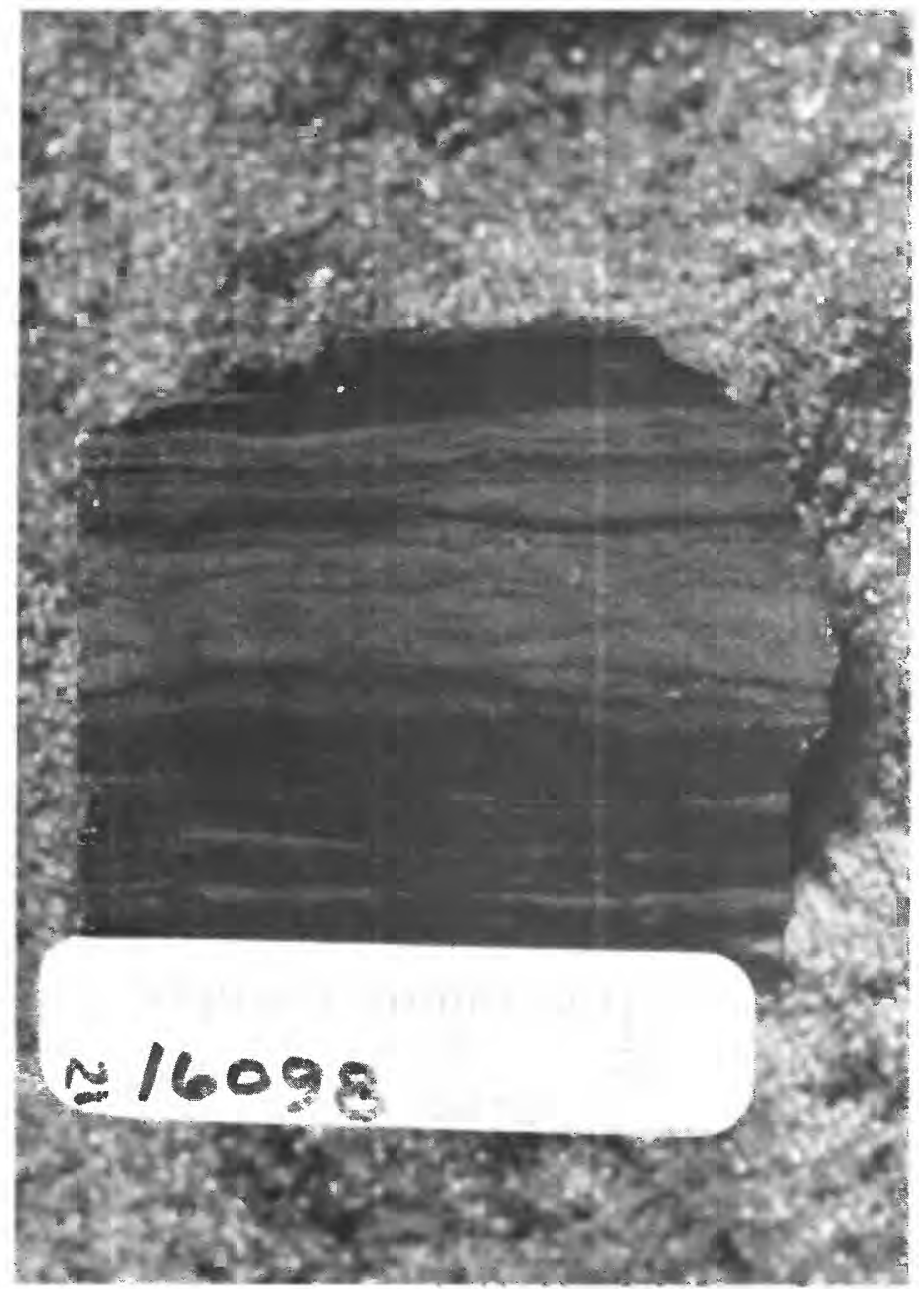

2-7. Ripple laminations in siltstone. Depth $16,098 \mathrm{ft}$.

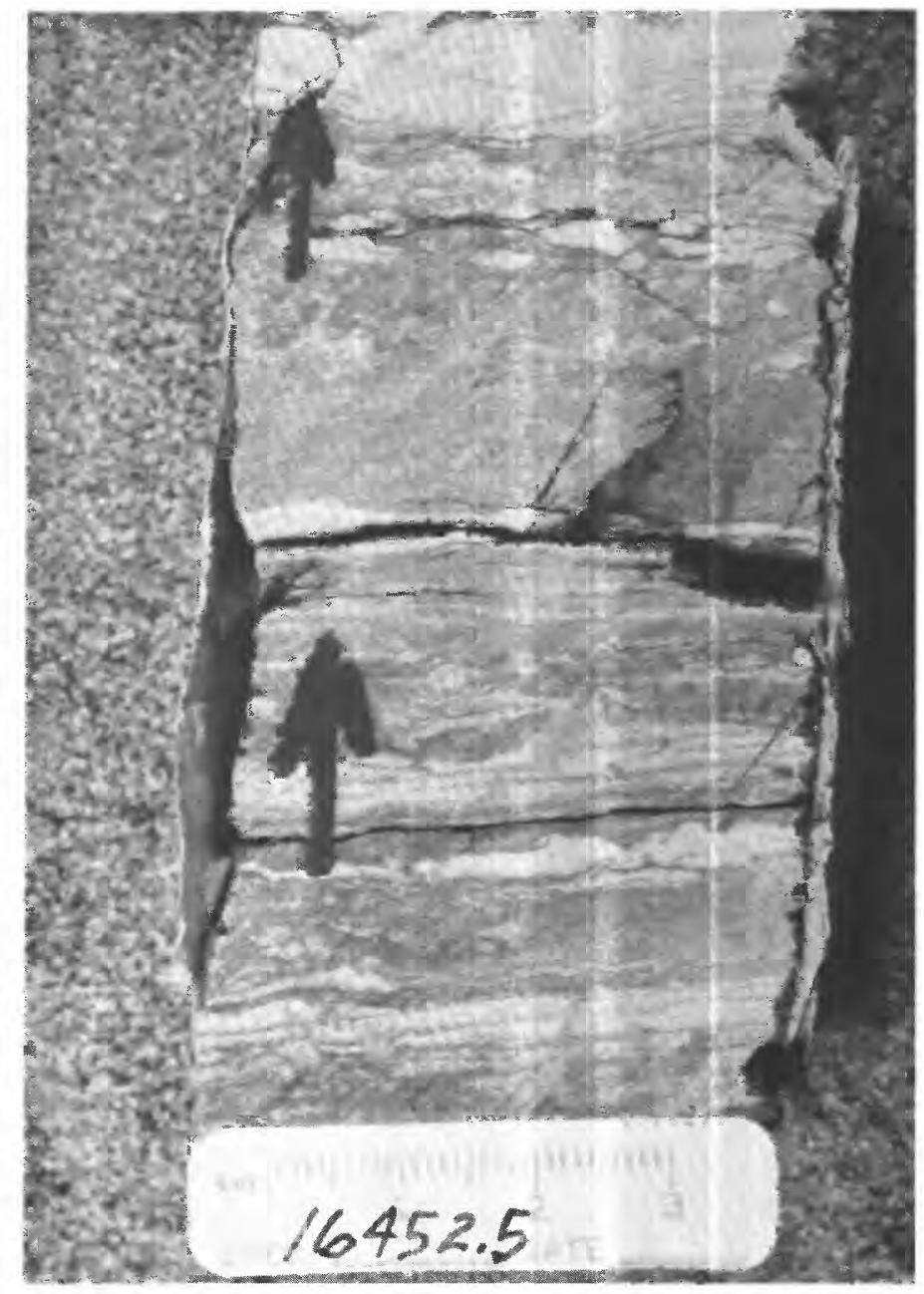

2-8. Combination of vertical and horizontal burrows in flaser unit in siltstone. Depth $16,425.5 \mathrm{ft}$. 


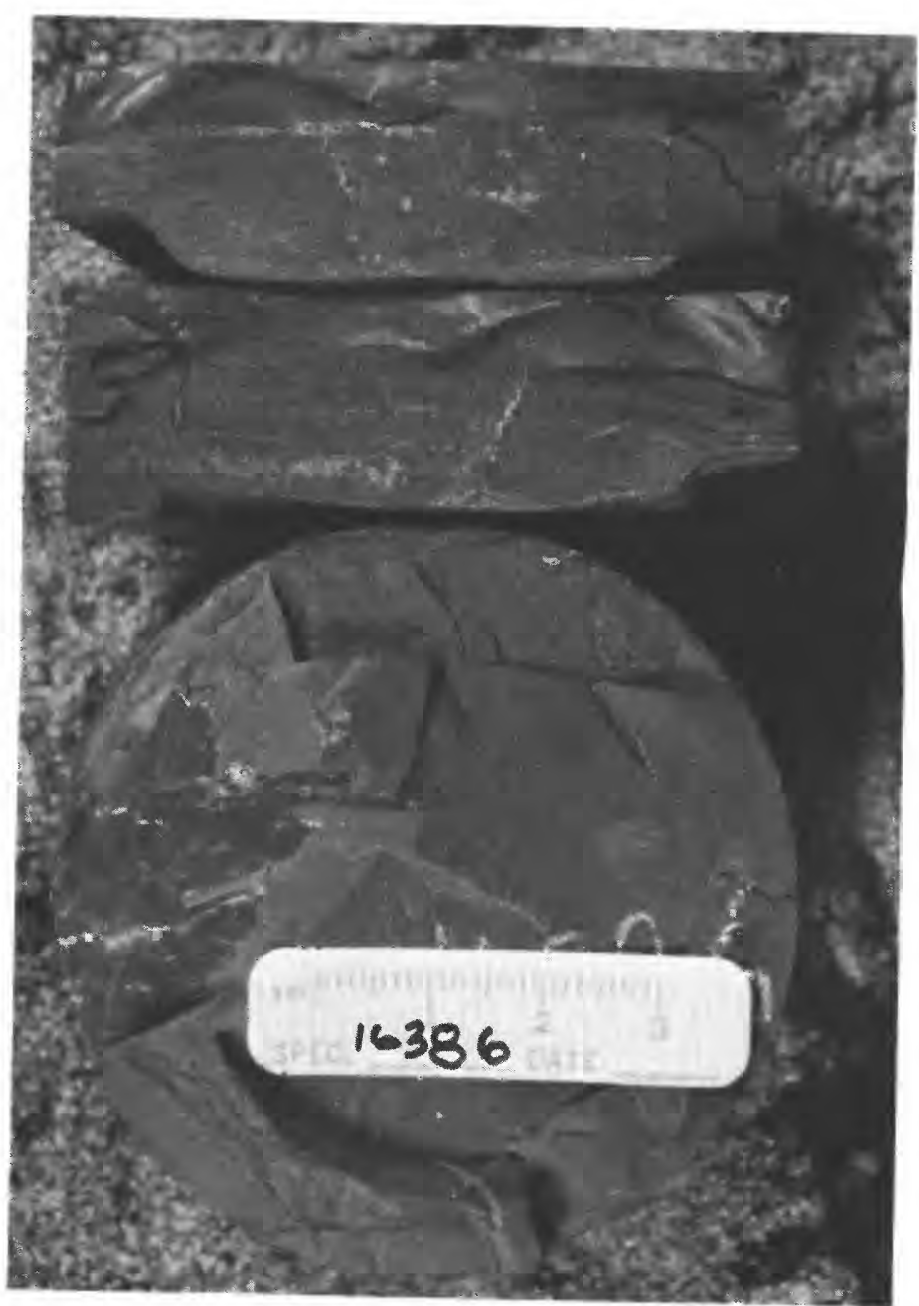

2-9. Dark-gray, waxy mudstone. Depth $16,386 \mathrm{ft}$.

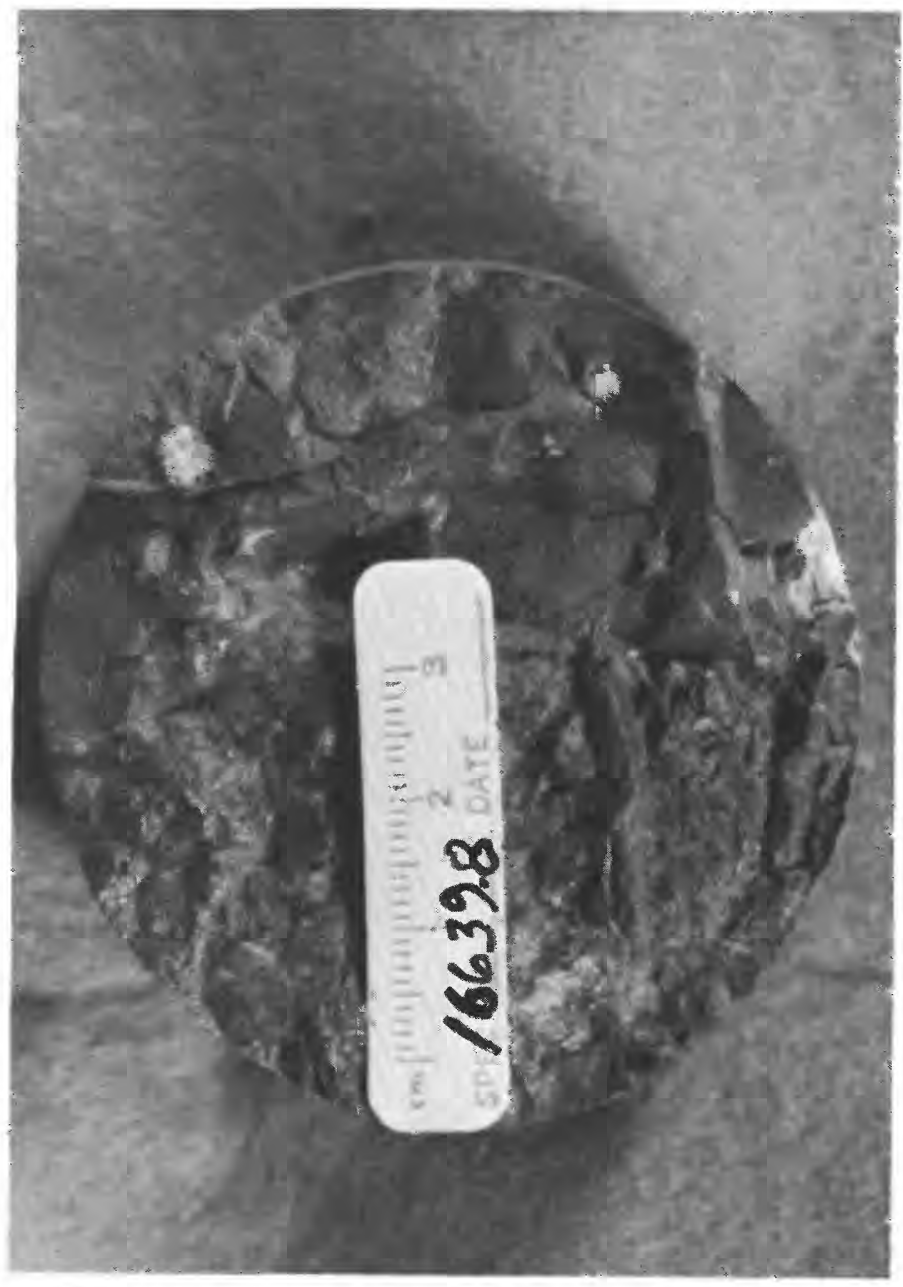

2-10. Vertical and horizontal burrows in mudstone. Depth $16,396.8 \mathrm{ft}$. 


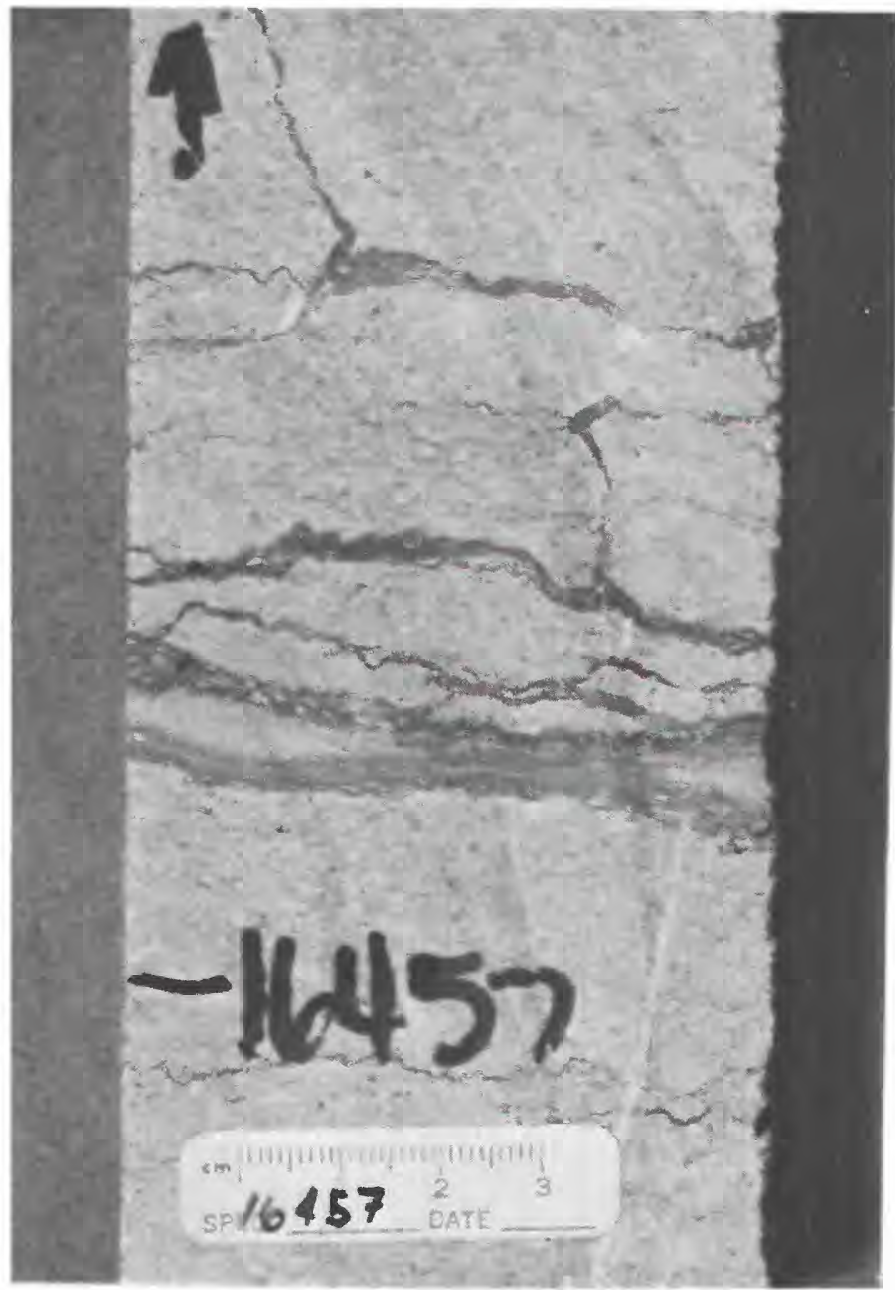

2-11. Light-gray dolomitic limestone (biosparite) interbedded with light-gray micrite. Depth $16,457 \mathrm{ft}$.

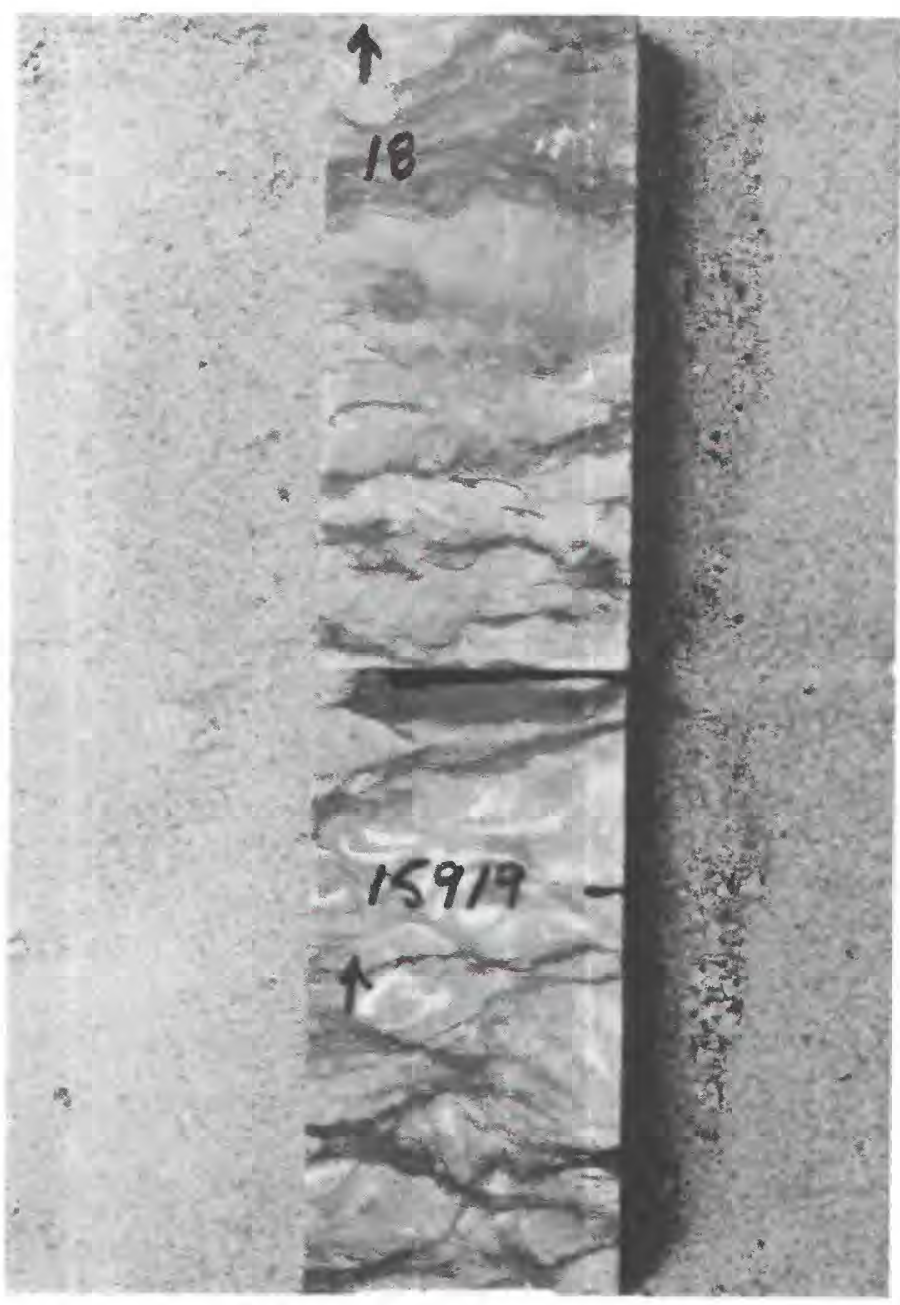

2-12. Nodular bedding of limestone; local concentrations of brachiopod fossils. Depth 15,919 ft. 


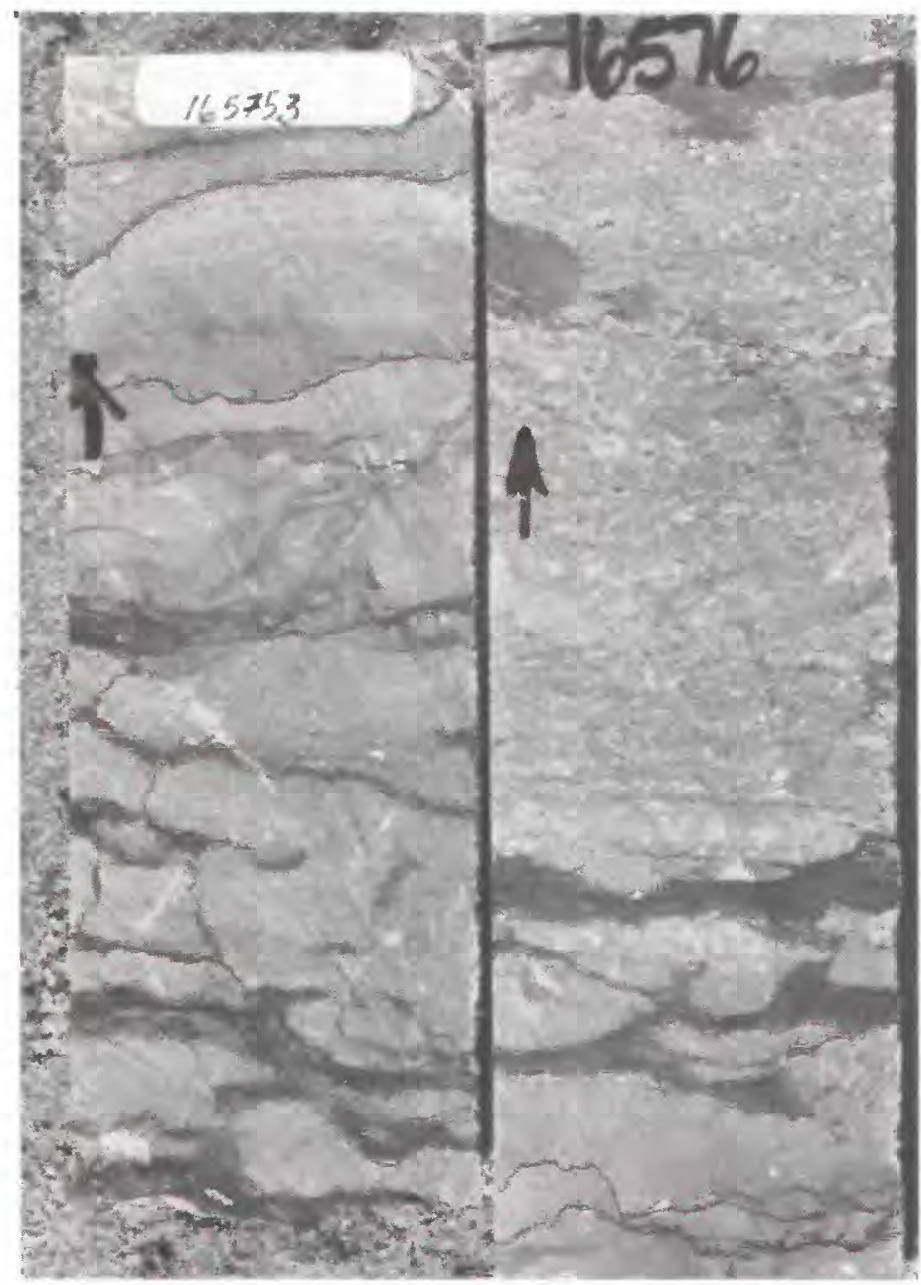

2-13. Dessication mudcracks in limestone. Depth $16,575.3 \mathrm{ft}$.

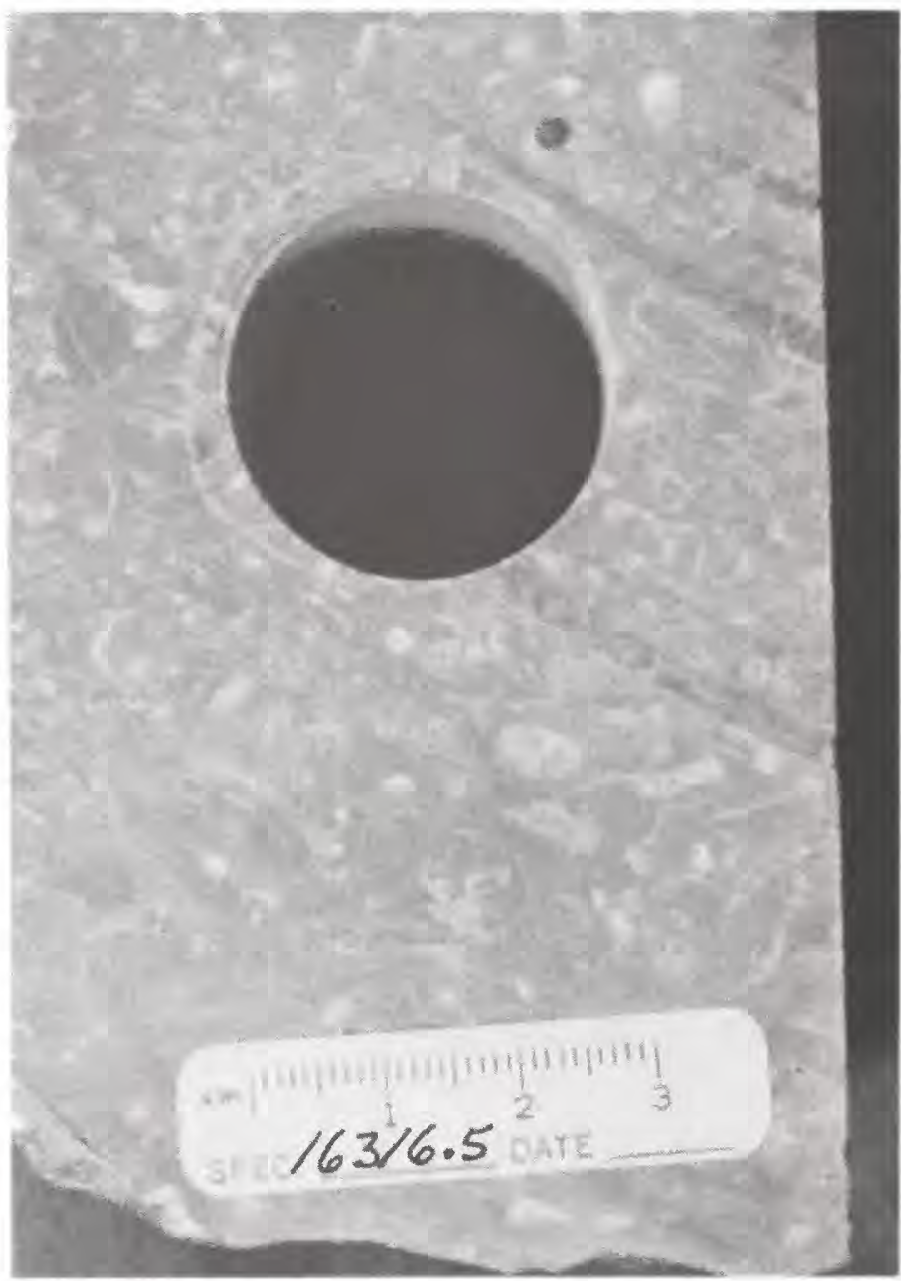

2-14. Brachiopod and crinoid fossil fragments in limestone. Depth $16,316.5 \mathrm{ft}$. 
Appendix 3. Photomicrographs showing features typical of core samples from the Middle Ordovician Simpson Group, Mazur well. Depths below surface.

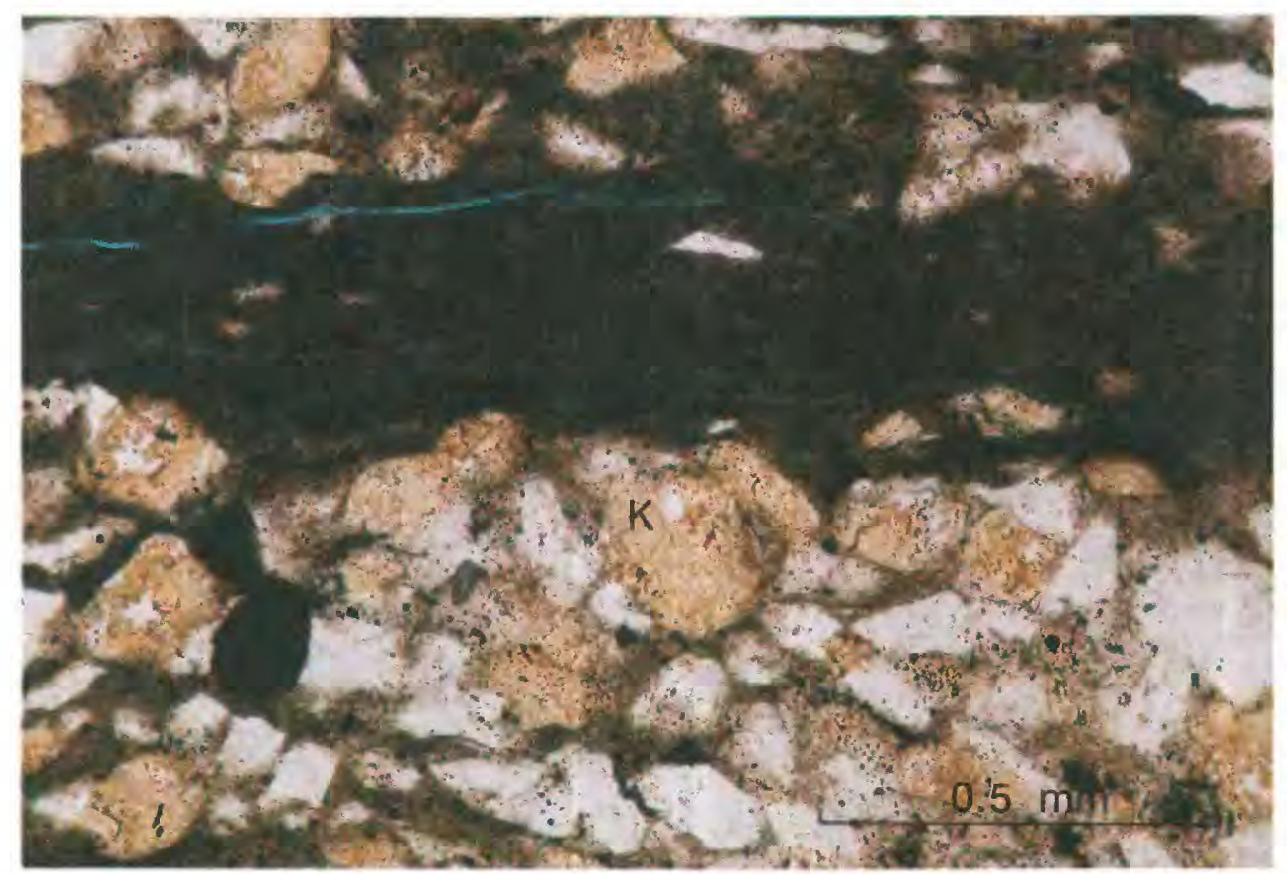

3-1. Sandy siltstone containing potassium feldspar ( $K$ ). Scale bar $0.5 \mathrm{~mm}$; plane-polarized light. McLish Formation, 16,422 ft.

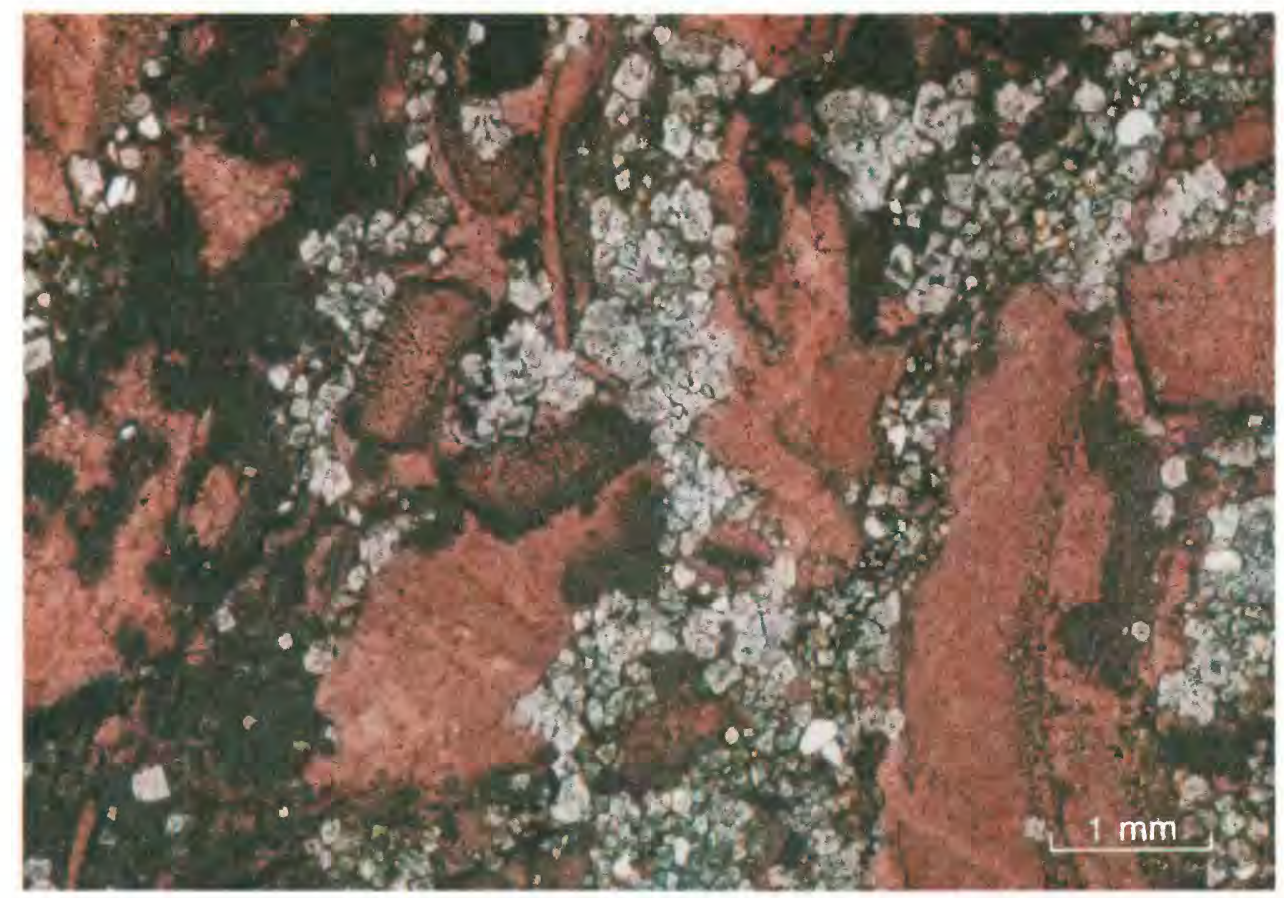

3-2. Fragments of brachiopods and crinoids (red-stained calcite) surrounded by (slightly) iron-bearing dolomite(?). Scale bar $0.1 \mathrm{~mm}$; plane-polarized light. Tulip Creek Formation, $16,832.9 \mathrm{ft}$. 


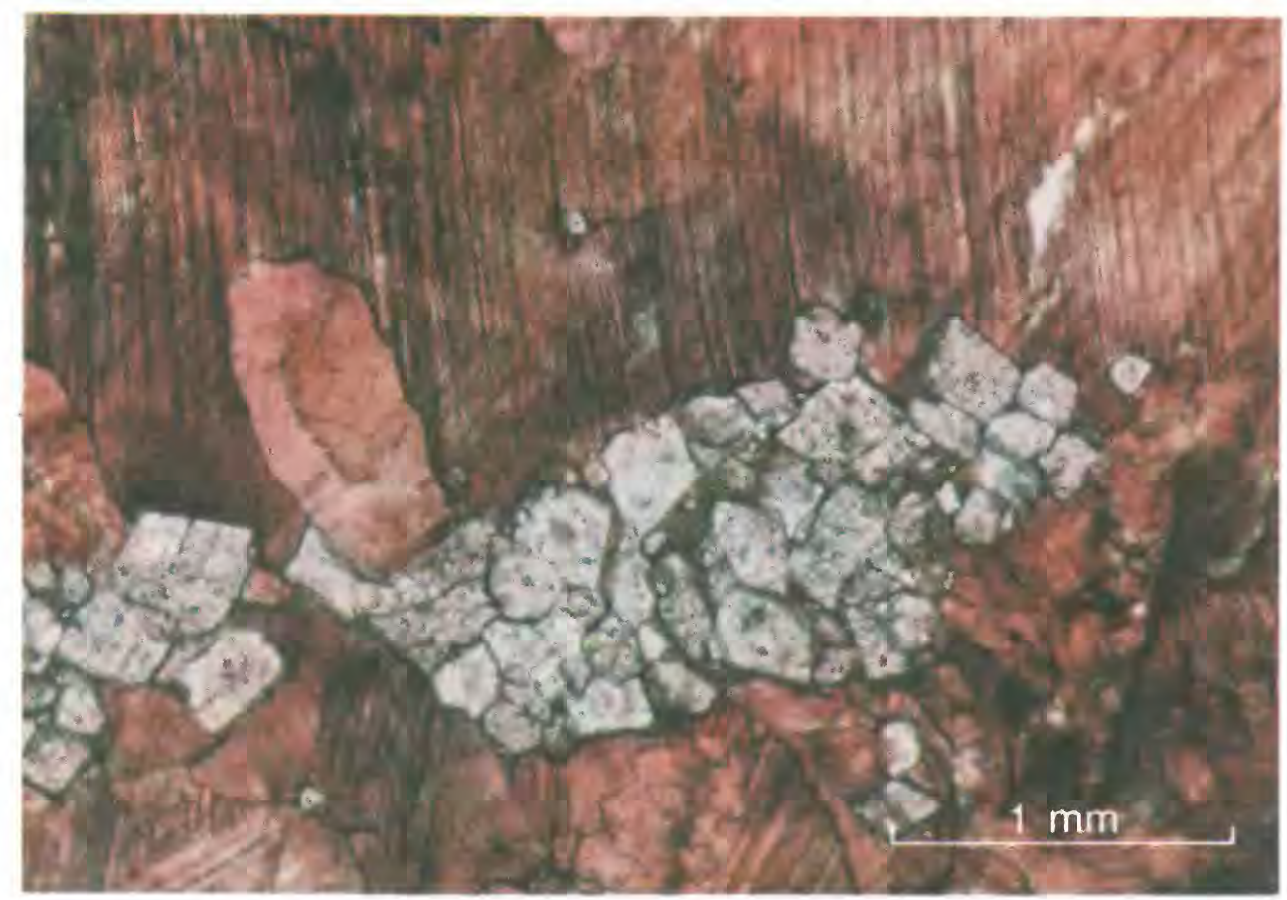

3-3. Rhombohedral crystals of dolomite(?) surrounded by poikilotopic calcite. Scale bar 1 $\mathrm{mm}$; plane-polarized light. McLish Formation, 16,555.3 ft.

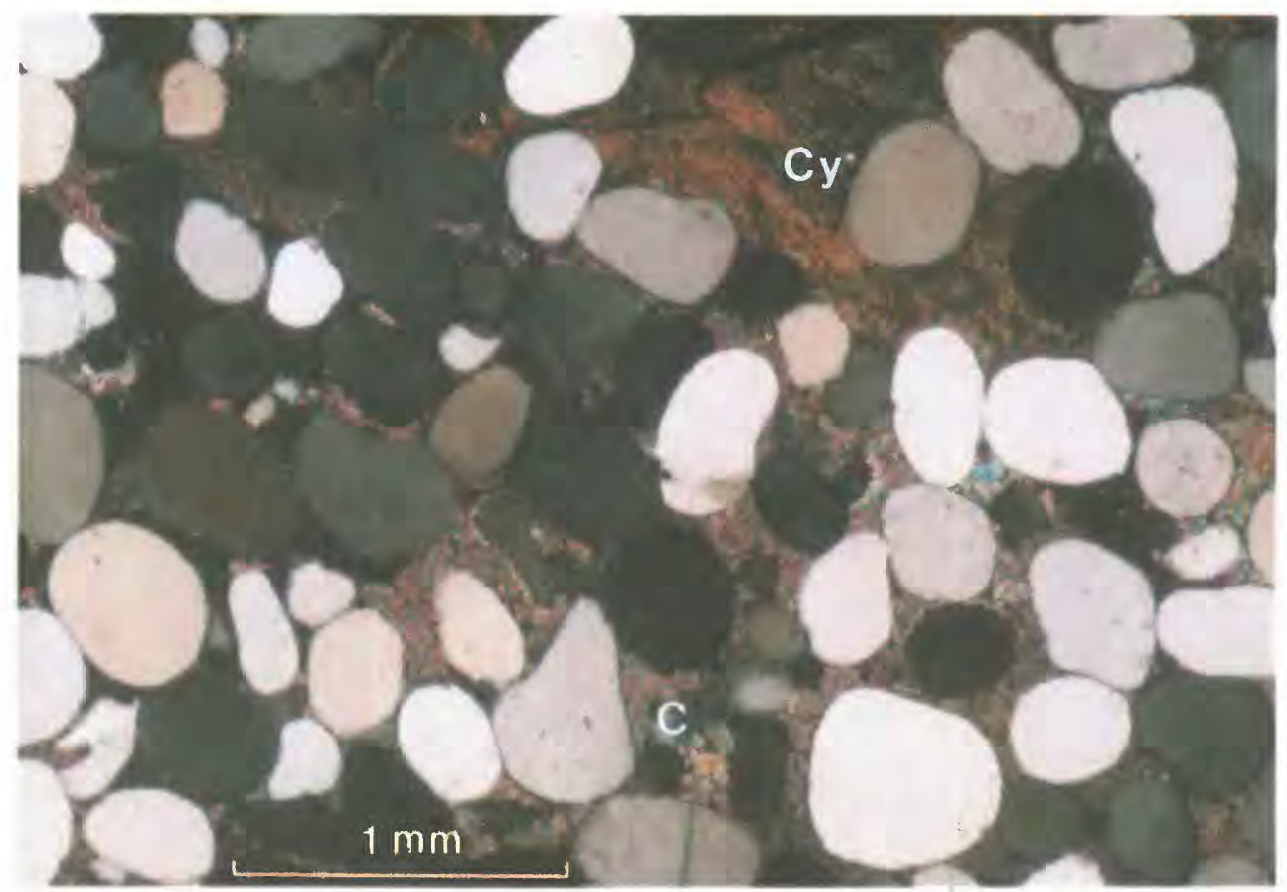

3-4. Sandstone, very tightly cemented by calcite (C); some quartz grains embedded in clay clast (Cy). Scale bar $1 \mathrm{~mm}$; crossed nicols. Bromide Formation, 15,928.9 ft. 


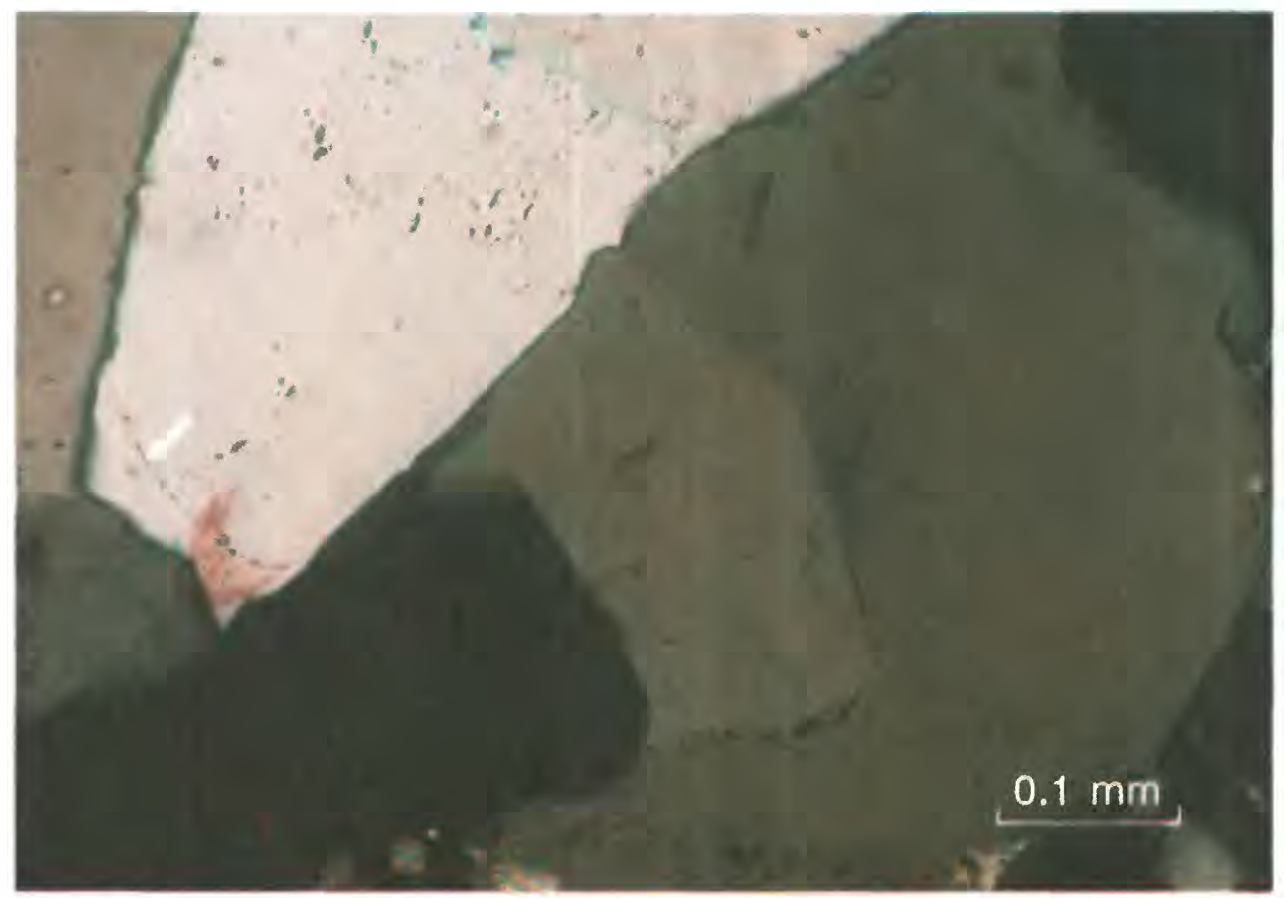

3-5. Intergranular quartz overgrowths (arrows) on rounded quartz grains and polycrystalline quartz grains. Scale bar $0.1 \mathrm{~mm}$; crossed nicols. Tulip Creek Formation, 16,338 ft.

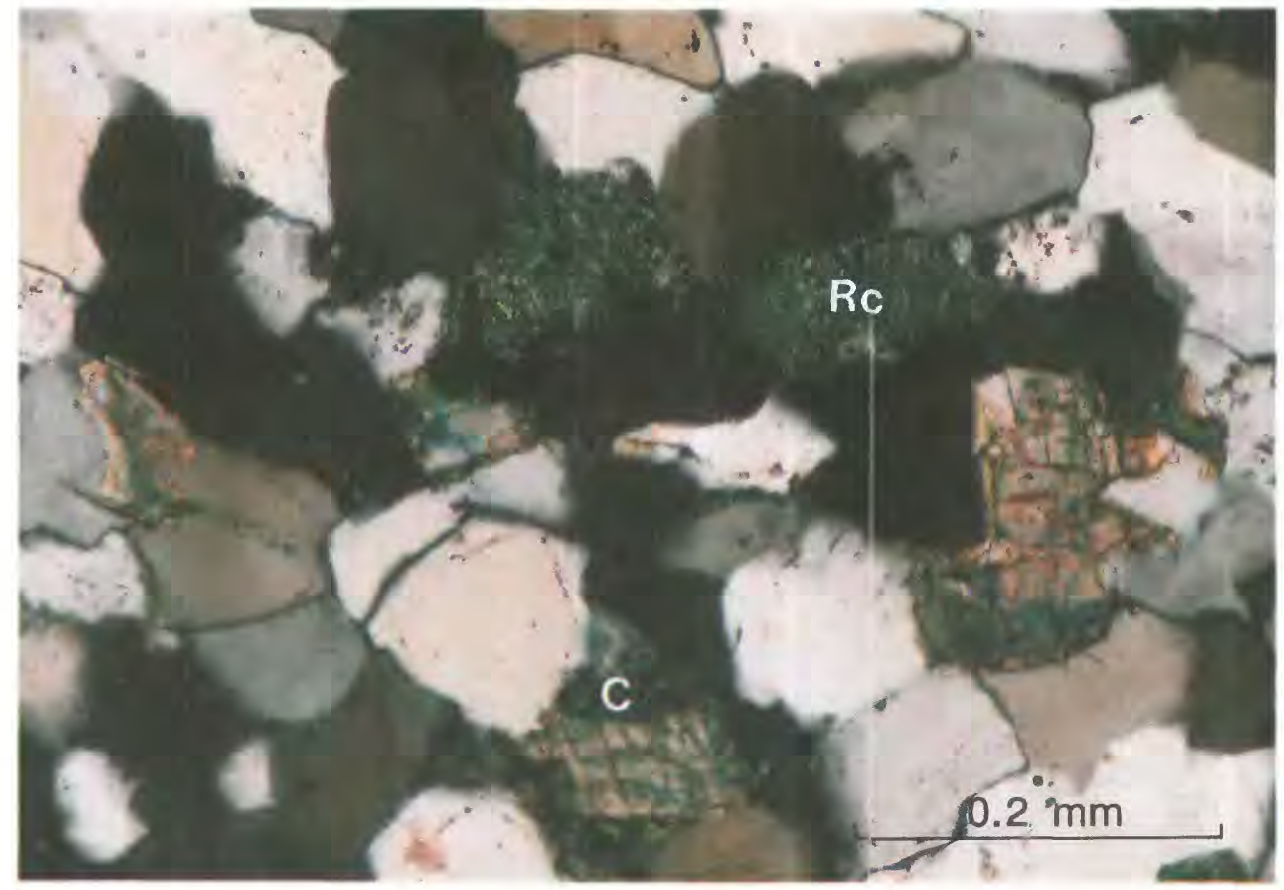

3-6. Low-porosity sandstone containing angular to subangular grains of quartz, partially leached chert (Rc), and calcite (C), which has replaced some earlier detrital minerals. Scale bar $0.2 \mathrm{~mm}$; crossed nicols. Tulip Creek Formation, 16,354 ft. 


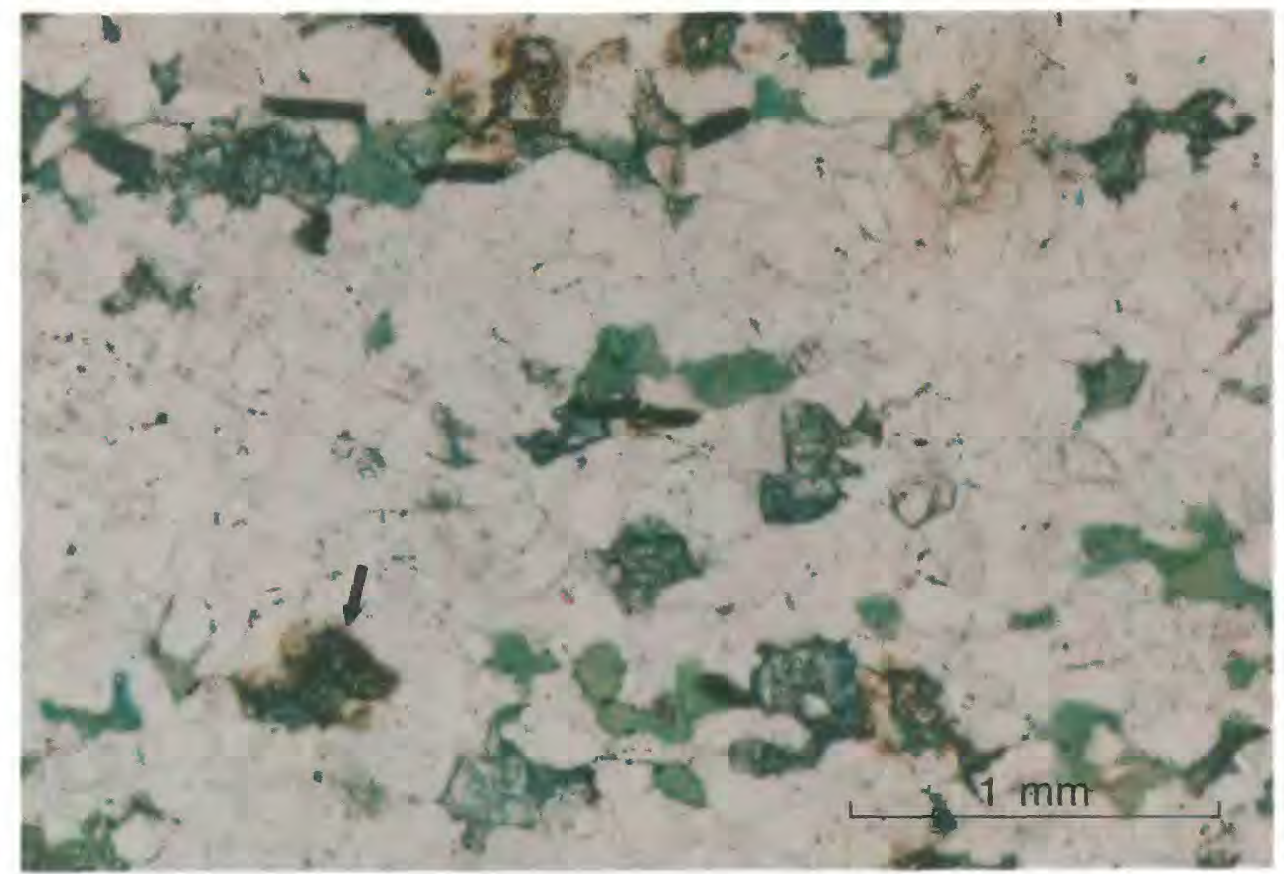

3-7. Low-porosity sandstone; porosity essentially limited to partially leached chert grains (arrow). Scale bar $1 \mathrm{~mm}$; plane-polarized light. Tulip Creek Formation, 16,354 ft.

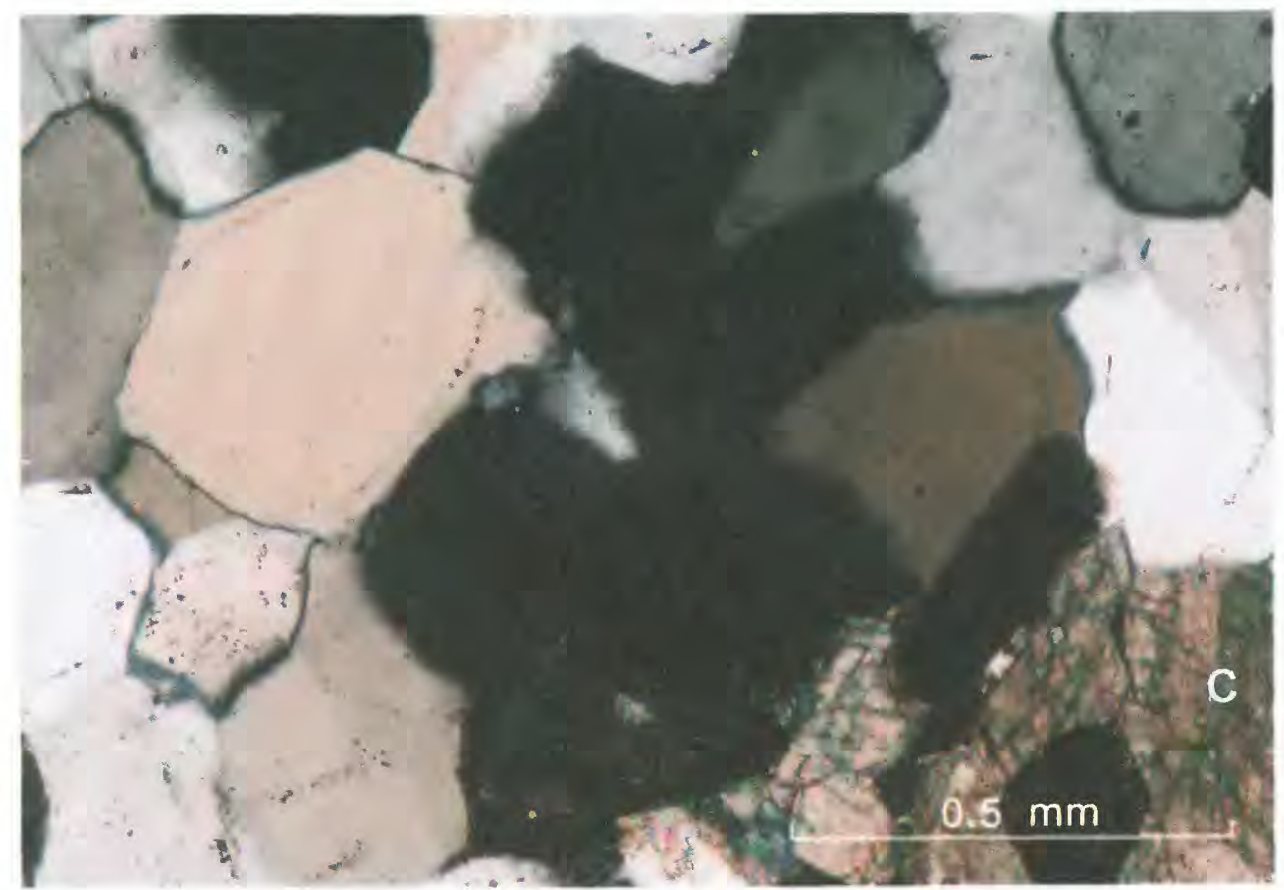

3-8. Sandstone cemented by quartz overgrowths and intergranular poikilotopic calcite (C). Scale bar $0.5 \mathrm{~mm}$; crossed nicols. Tulip Creek Formation, 16,338 ft. 


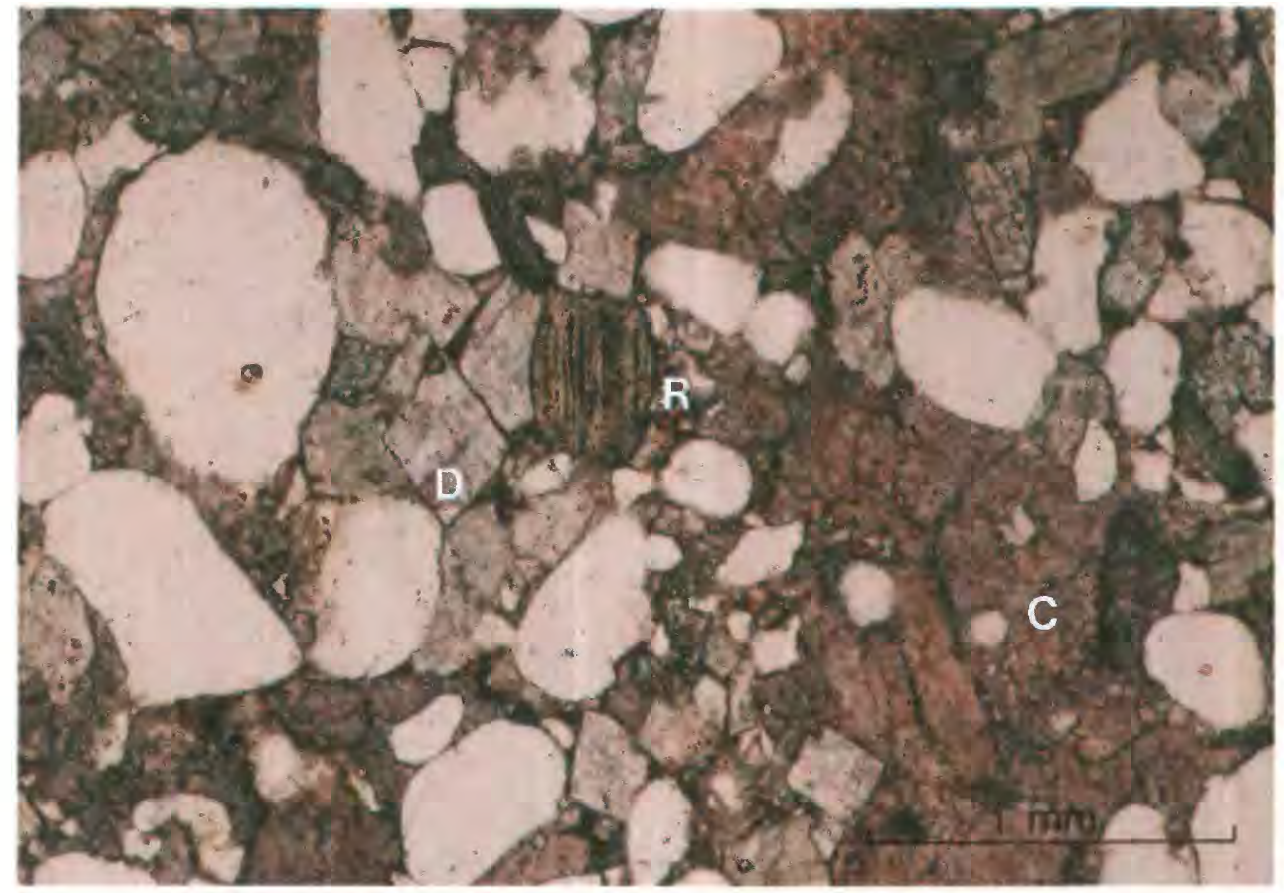

3-9. Rhombohedral grains of iron-bearing dolomite (D) intergrown in poikilotopic calcite (C), and detrital quartz grains and rock fragments (R). Scale bar $1 \mathrm{~mm}$; plane-polarized light. Tulip Creek Formation, 16,302 ft.

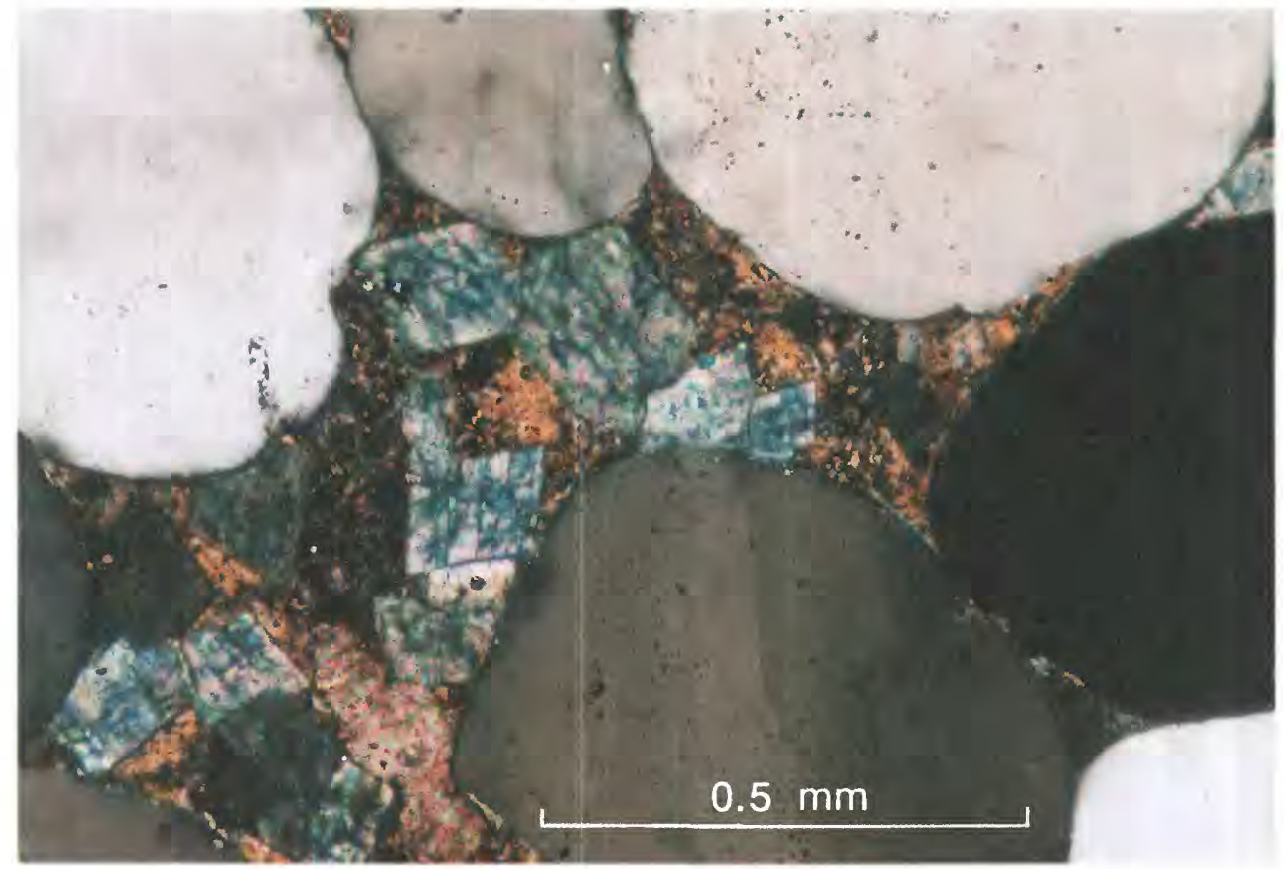

3-10. Rhombohedral grains of iron-bearing carbonate (ankerite?) in intergranular matrixpseudomatrix of clay between subrounded detrital quartz grains. Scale bar $0.5 \mathrm{~mm}$; crossed nicols. Bromide Formation, 15,966 ft. 


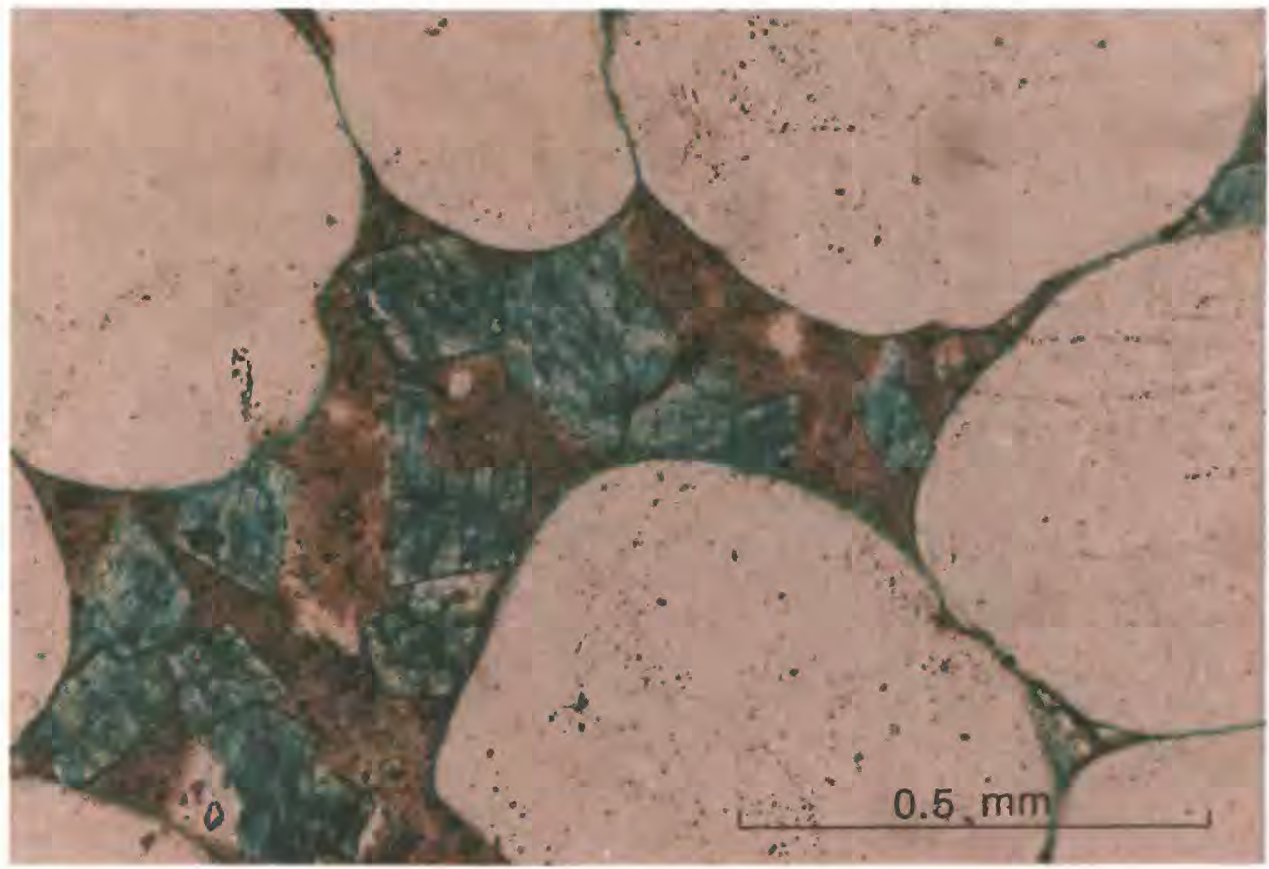

3-11. Same as photograph 10; plane-polarized light.

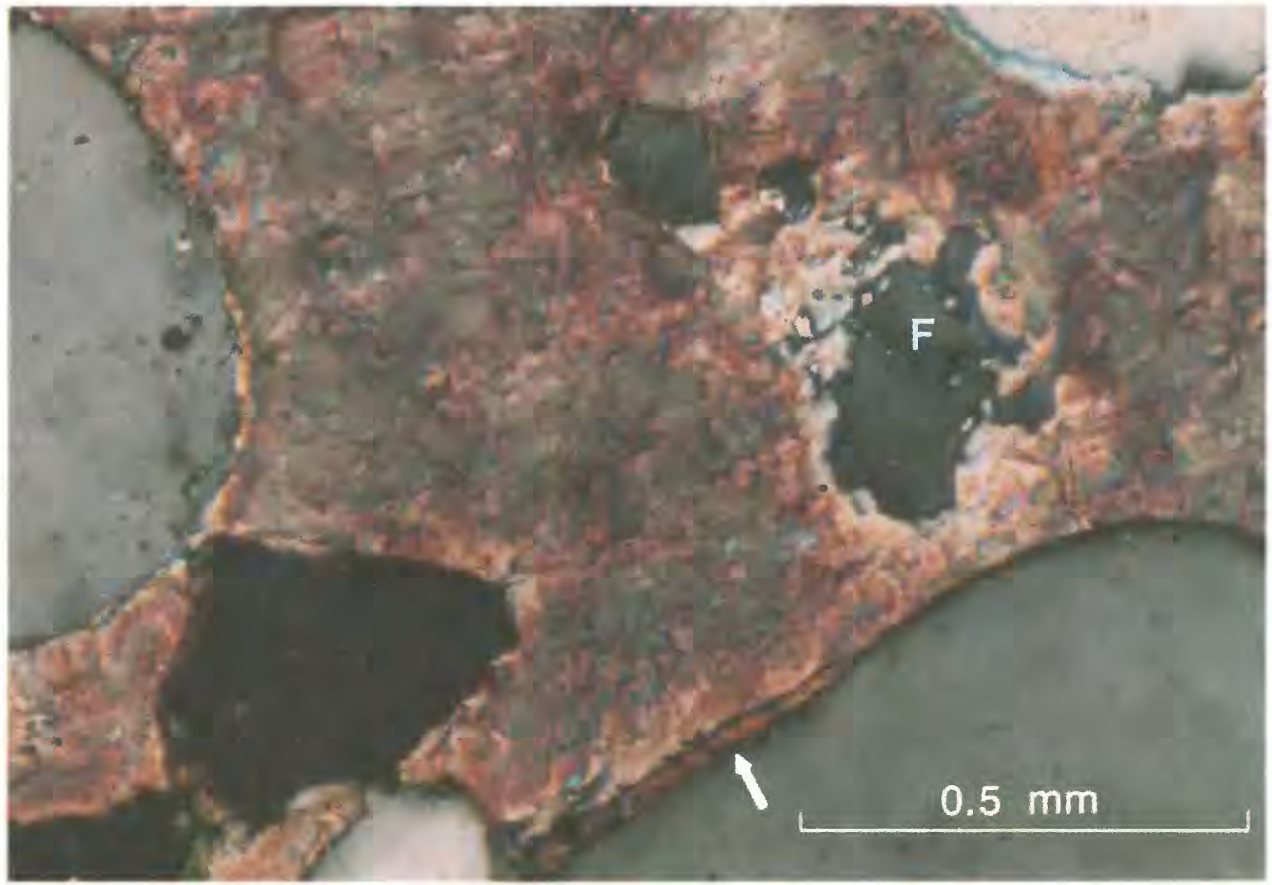

3-12. Remnant of feldspar(?) (F) in intergranular, pore-filling calcite; thin layer of clay (arrow) partially coats one quartz grain. Scale bar $0.5 \mathrm{~mm}$; crossed nicols. Tulip Creek Formation, $16,251 \mathrm{ft}$. 


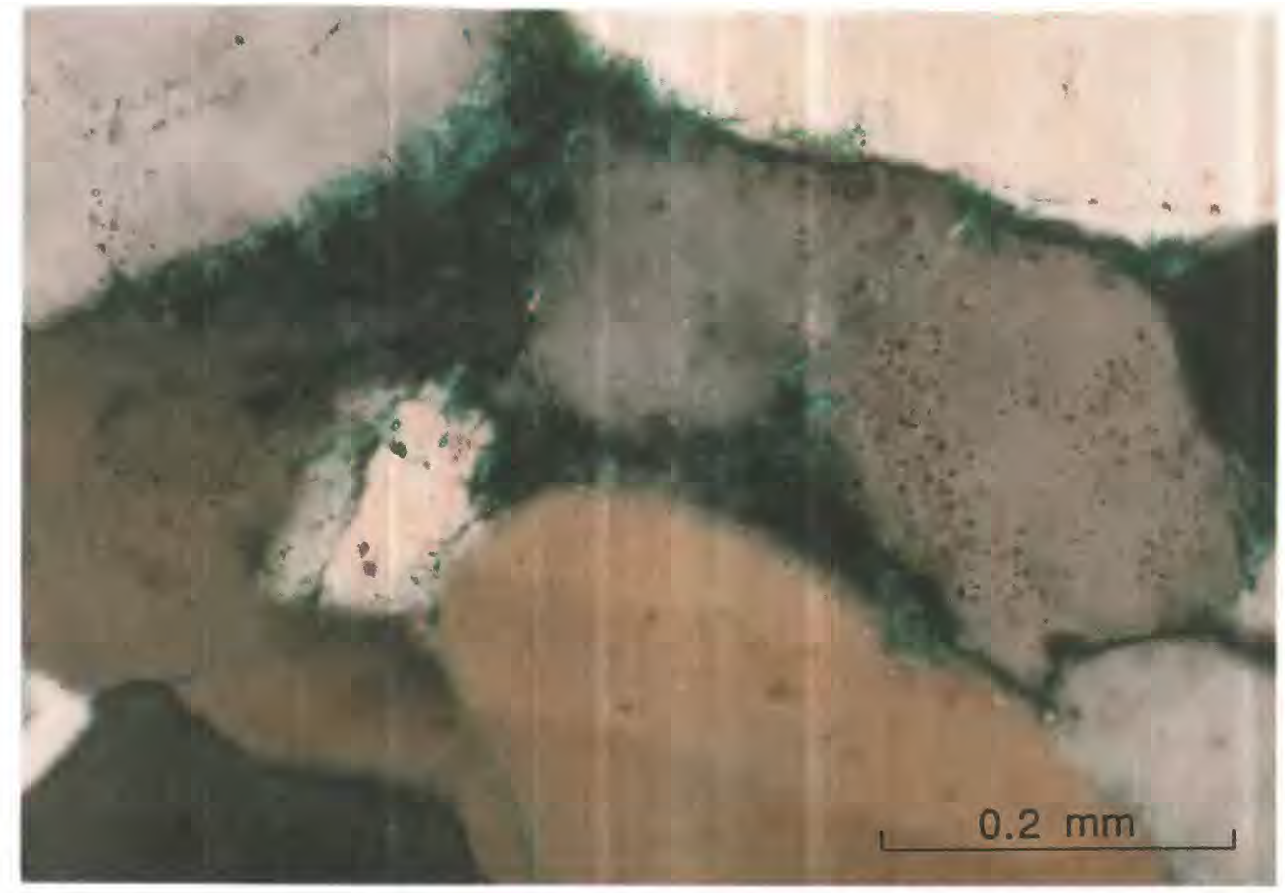

3-13. Intergranular porosity and slight dissolution of quartz grain surfaces. Scale bar 0.2 $\mathrm{mm}$; crossed nicols. Tulip Creek Formation, 16,230 ft. 





\section{SELECTED SERIES OF U.S. GEOLOGICAL SURVEY PUBLICATIONS}

\section{Periodicals}

Earthquakes \& Volcanoes (issued bimonthly).

Preliminary Determination of Epicenters (issued monthly).

\section{Technlcal Books and Reports}

Professional Papers are mainly comprehensive scientific reports of wide and lasting interest and importance to professional scientists and engineers. Included are reports on the results of resource studies and of topographic, hydrologic, and geologic investigations. They also include collections of related papers addressing different aspects of a single scientific topic.

Bulletins contain significant data and interpretations that are of lasting scientific interest but are generally more limited in scope or geographic coverage than Professional Papers. They include the results of resource studies and of geologic and topographic investigations; as well as collections of short papers related to a specific topic.

Water-Supply Papers are comprehensive reports that present significant interpretive results of hydrologic investigations of wide interest to professional geologists, hydrologists, and engineers. The series covers investigations in all phases of hydrology, including hydrogeology, availability of water, quality of water, and use of water.

Circulars present administrative information or important scientific information of wide popular interest in a format designed for distribution at no cost to the public. Information is usually of short-term interest.

Water-Resources Investigations Reports are papers of an interpretive nature made available to the public outside the formal USGS publications series. Copies are reproduced on request unlike formal USGS publications, and they are also available for public inspection at depositories indicated in USGS catalogs.

Open-File Reports include unpublished manuscript reports, maps, and other material that are made available for public consultation at depositories. They are a nonpermanent form of publication that may be cited in other publications as sources of information.

\section{Maps}

Geologic Quadrangle Maps are multicolor geologic maps on topographic bases in $71 / 2$ - or 15 -minute quadrangle formats (scales mainly $1: 24,000$ or $1: 62,500$ ) showing bedrock, surficial, or engineering geology. Maps generally include brief texts; some maps include structure and columnar sections only.

Geophysical Investigations Maps are on topographic or planimetric bases at various scales; they show results of surveys using geophysical techniques, such as gravity, magnetic, seismic, or radioactivity, which reflect subsurface structures that are of economic or geologic significance. Many maps include correlations with the geology.

Miscellaneous Investigations Series Maps are on planimetric or topographic bases of regular and irregular areas at various scales; they present a wide variety of format and subject matter. The series also includes $71 / 2$-minute quadrangle photogeologic maps on planimetric bases which show geology as interpreted from aerial photographs. Series also includes maps of Mars and the Moon.
Coal Investigations Maps are geologic maps on topographic $\mathrm{Cr}$ planimetric bases at various scales showing bedrock or surficial geo'ogy, stratigraphy, and structural relations in certain coal-resource areas.

Oil and Gas Investigations Charts show stratigraphic information for certain oil and gas fields and other areas having petroleum potentia ${ }^{1}$.

Miscellaneous Field Studies Maps are multicolor or black-anc'white maps on topographic or planimetric bases on quadrangle or irregular areas at various scales. Pre-1971 maps show bedrock geolog" in relation to specific mining or mineral-deposit problems; post-1971 maps are primarily black-and-white maps on various subjects such a* environmental studies or wilderness mineral investigations.

Hydrologic Investigations Atlases are multicolored or black-and. white maps on topographic or planimetric bases presenting a wide rang ? of geohydrologic data of both regular and irregular areas; principal scal ? is $1: 24,000$ and regional studies are at $1: 250,000$ scale or smaller.

\section{Catalogs}

Permanent catalogs, as well as some others, giving comprehen. sive listings of U.S. Geological Survey publications are available undethe conditions indicated below from the U.S. Geological Survey, Bookand Open-File Reports Section, Federal Center, Box 25425, Denver, CO 80225. (See latest Price and Availability List.)

"Publications of the Geological Survey, 1879-1961" may be purchased by mail and over the counter in paperback book form and as a set of microfiche.

"Publications of the Geological Survey, 1962- 1970" may be purchased by mail and over the counter in paperback book form and as a set of microfiche.

"Publications of the U.S. Geological Survey, 1971- 1981" may be purchased by mail and over the counter in paperback book form (two volumes, publications listing and index) and as a set of microfiche.

Supplements for 1982, 1983, 1984, 1985, 1986, and for subsequen: years since the last permanent catalog may be purchased by mail and over the counter in paperback book form.

State catalogs, "List of U.S. Geological Survey Geologic and' Water-Supply Reports and Maps For (State)," may be purchased by mail and over the counter in paperback booklet form only

"Price and Availability List of U.S. Geological Survey Publications," issued annually, is available free of charge in paperback booklet form only.

Selected copies of a monthly catalog "New Publications of the U.S. Geological Survey" available free of charge by mail or may be obtained over the counter in paperback booklet form only. Those wishing a free subscription to the monthly catalog "New Publications of the U.S. Geological Survey" should write to the U.S. Geological Survey, 582 National Center, Reston, VA 22092.

Note.--Prices of Government publications listed in older catalogs, announcements, and publications may be incorrect. Therefore, the prices charged may differ from the prices in catalogs, announcements, and publications. 


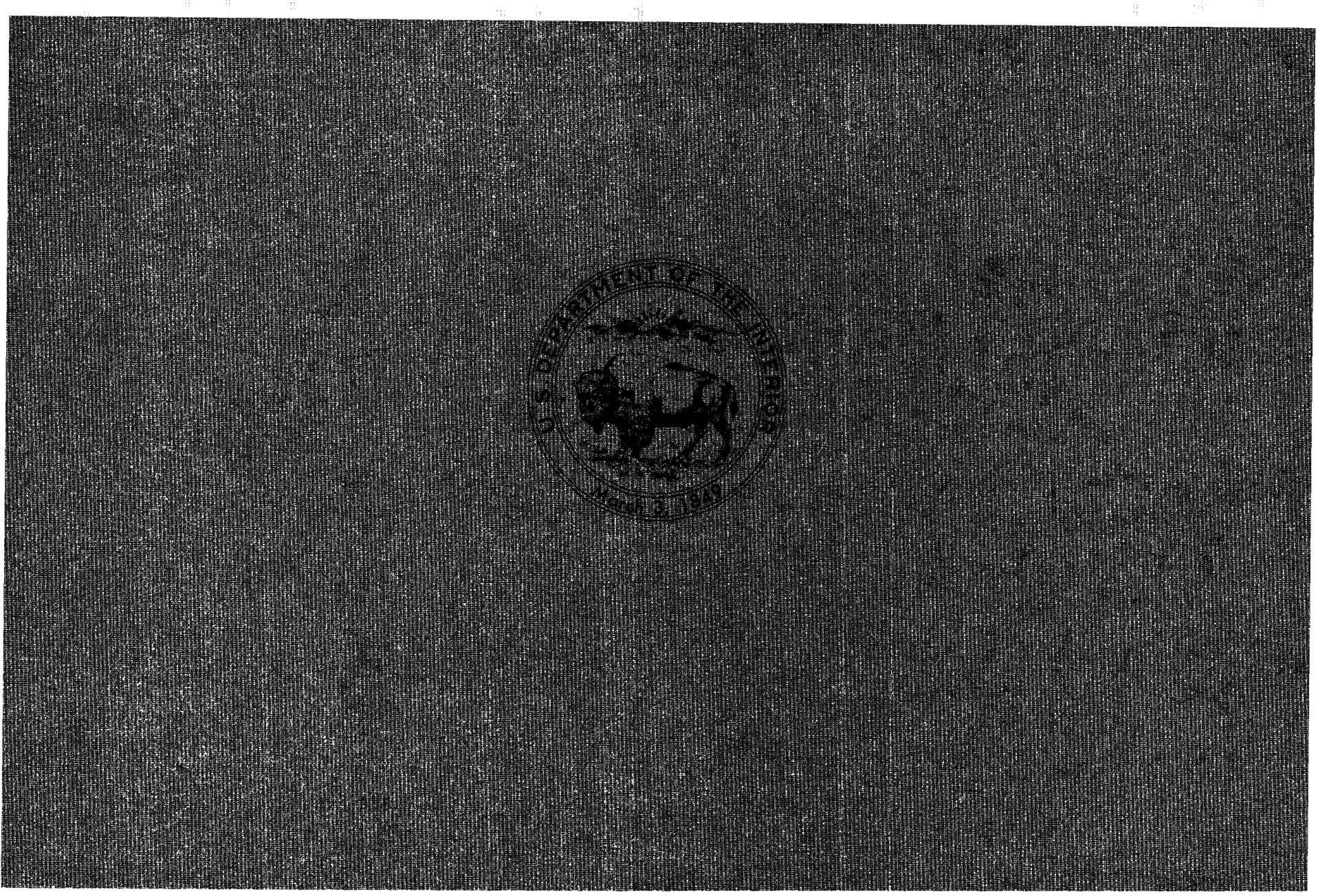

